INSTITUTO DE PESQUISAS ENERGÉTICAS E NUCLEARES

Autarquia associada à Universidade de São Paulo

PROSPECÇÃO TECNOLÓGICA DE BIOBUTANOL NO CONTEXTO BRASILEIRO DE BIOCOMBUSTÍVEIS

JÚLIO CÉSAR NATALENSE

Dissertação apresentada como parte dos requisitos para obtenção do Grau de Mestre em Ciências na Área de Tecnologia Nuclear Aplicações.

Orientadora:

Profa. Dra. Désirée Moraes Zouain

SÃO PAULO

2013 


\title{
PROSPECÇÃO TECNOLÓGICA DE BIOBUTANOL NO CONTEXTO BRASILEIRO DE BIOCOMBUSTÍVEIS
}

\author{
Júlio César Natalense
}

\begin{abstract}
RESUMO
Dois exemplos de combustíveis renováveis em uso atualmente são bioetanol e biodiesel. Novas alternativas de combustíveis incluem etanol celulósico e biobutanol. Estes apresentam vantagens pois contribuem para uma melhor produtividade e otimização do uso de biomassa. Possuem ainda boas propriedades que garantem o bom desempenho como combustíveis. A pesquisa e interesse industrial têm crescido sobre o biobutanol, com melhorias no processo tradicional de fermentação ABE (Acetona-Butanol-Etanol), desenvolvimento de novos microorganismos para aumentar o rendimento e técnicas de separação para isolar o solvente do meio fermentativo. Algumas companhias anunciaram planos para a introdução de biobutanol em misturas com gasolina no mercado norte-americano. O interesse por biobutanol no Brasil como combustível ainda é limitado, pois a infraestrutura de comercialização já é adaptada ao uso de bioetanol, e a maior parte da frota de carros circulante utiliza motores adaptados ao uso do bioetanol. A cana-de-açúcar pode ser utilizada como matéria prima no processo produtivo do biobutanol, capacitando o Brasil a tornar-se um importante exportador para suprir o biobutanol para outros países. Em curto prazo, o biobutanol poderá ser produzido no Brasil para substituir o petro-butanol como solvente em aplicações industriais ou para o mercado de exportação como combustível. O presente trabalho propõe 0 uso da técnica technology roadmapping para o planejamento estratégico do desenvolvimento do biobutanol, alinhando os objetivos de longo prazo com os recursos, linhas de financiamento e prioridades para atender as necessidades do processo de desenvolvimento.
\end{abstract}




\title{
TECHNOLOGY ROADMAPPING FOR BIOBUTANOL IN THE BRAZILIAN BIOFUELS MARKET
}

\author{
Júlio César Natalense
}

\begin{abstract}
Two examples of renewable fuels in use today are bioethanol and biodiesel. New alternatives on biofuels include cellulosic ethanol and biobutanol. They present several advantages over the conventional biofuels, either in terms of better productivity and optimization of the use of biomass, as well as higher performance attributes. The research and industrial interest has grown on biobutanol, with improvements on the traditional ABE fermentation process, on the development of new microorganism strains to improve yield, and separation techniques to isolate the solvent. Companies have announced plans for the introduction of biobutanol in blends with gasoline in the north-american market. The interest on biobutanol as a fuel in Brazil is still limited, since the infrastructure is tailored to bioethanol already, and most of the car fleet uses engines adapted to this fuel. Sugar cane can be used as a potential feedstock in the butanol production process, enabling Brazil to become a key exporter to supply biobutanol to other countries. For the short future biobutanol will be produced in Brazil to replace petro-butanol as a solvent in industrial applications only, or for the export market as a fuel. This work proposes the use of technology roadmapping as a technique for long term strategic planning of the biobutanol development, aligning long term goals with the resources, funding, and priorities to fulfill the needs in the development process.
\end{abstract}




\section{AGRADECIMENTOS}

A realização deste trabalho somente foi possível com a contribuição de diversas pessoas. Destas, faço particular agradecimento as que exerceram influência direta para a conclusão desta importante fase em minha vida.

A minha orientadora, Professora Dra. Désirée Moraes Zouain, pela competência, orientação precisa, e compartilhamento de sua experiência e conhecimento.

Ao Instituto de Pesquisas Energéticas e Nucleares e a Universidade de São Paulo, pela oportunidade de integrar o Programa de Mestrado em Tecnologia Nuclear e Aplicações.

Aos professores do IPEN que aprendi a admirar, Dr. Antônio Carlos de Oliveira Barroso e Dr. Gerson Marinucci.

Aos especialistas Dr. Paulo Luiz de Andrade Coutinho e Dr. Maicon Oliveira, por sua iniciativa em adotar os technology roadmaps no Brasil.

Ao amigo Victor Hugo Monje, por sua dedicação em abrir caminhos para que mais pessoas possam vencer. Aos amigos Dr. Abel de Oliveira, Dr. Rui Cruz, Marcos Pini França, Marcelo Graziani e Rodrigo Rocha, pelo apoio, compartilhamento de ferramentas de busca e análise estatística. A Franklin Carvalho, Adrianne Pedrosa e Ana Maria Inglez de Souza pela facilitação de contatos no segmento de energia renovável.

Aos especialistas que contribuiram com este trabalho, Dr. Luis Augusto Barbosa Cortez, Dr. Carlos Rossell, Dr. Rubens Maciel Filho, Dr. Celso Foelkel, Dr. Wilson Araújo, Rodrigo Matsushita, Francisco Pellegrini, Richard Macret, Rafael Pellicciotta, Selma Jaconis e Romeo Bulla.

Ao Dr. Jonathan Budd, da Styron LLC, pelos ensinamentos em técnicas de busca e análise de patentes.

A minha esposa Alexandra, e a meus filhos, Érica e Rodrigo, pelo carinho e apoio em cada momento. 


\section{SUMÁRIO}

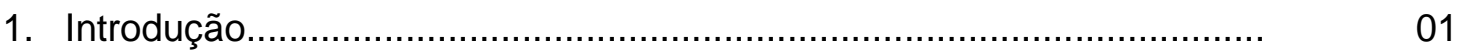

2. Objetivo da Pesquisa...................................................................... 05

3. Revisão Teórica................................................................................... 06

a. Technology Roadmaps

3.1 Perspectiva histórica........................................................ 06

3.2 Processo de construção do mapa tecnológico....................... 13

3.3 Benefícios do mapeamento tecnológico................................ 20

3.4 Aplicações em bioenergia...................................................... 22

3.5 Technology roadmaps para biocombustíveis no Brasil.......... 26

b. Butanol

3.6 Butanol - Perspectiva histórica........................................ 30

3.7 Butanol produtos, produção e usos....................................... 31

3.8 Tecnologias para produção de biobutanol por rota biológica. 34

3.8.1 Microorganismos................................................ 42

3.8.2 Tecnologia de Reatores de Fermentação................ 43

3.8.3 Técnicas de Recuperação de Solventes.................. 45

3.9 Butanol como combustível..................................................... 47

3.9.1 Biocombustíveis............................................. 47

3.9.3 Butanol como biocombustível............................. 50

3.9.3 Oportunidades para o biobutanol........................... 53

3.10 Empresas atuantes em biobutanol....................................... 55

4. Desenvolvimento do projeto de pesquisa.......................................... 58

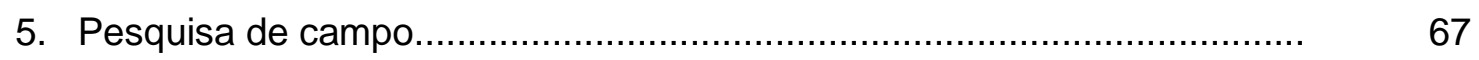

6. Resultados e discussão...................................................................... 69

6.1 Resultado das entrevistas - Mercado...................................... 69

6.2 Resultado das entrevistas - Produto...................................... 79

6.3 Resultado das entrevistas - Tecnologia............................... 81

7. Elaboração do Technology Roadmap Biobutanol no Brasil....................... 91

8. Conclusões e Futuras Direções de Pesquisa......................................... 94

Refêrencias Bibliográficas.................................................................. 99

Anexo A - Questionário de Pesquisa................................................ 111 


\section{Introdução}

A importância do investimento em tecnologia tem crescido no mundo atual. Com o incremento da competitividade global, é crucial dispor de ferramentas adequadas para o investimento apropriado em pesquisa e desenvolvimento, e o direcionamento dos esforços empregados pelas organizações. O gerenciamento da tecnologia necessita de processos que assegurem o correto uso dos recursos para atingir as necessidades das organizações. MARTINO (1993) defende a prospecção tecnológica como ferramenta útil ao planejador para estimativa das tecnologias que estarão disponíveis no futuro.

O processo de technology roadmapping é uma metodologia que permite construir o plano tecnológico de uma empresa, setor ou país, de maneira a garantir que as tecnologias estarão disponíveis a tempo para preencher as necessidades futuras do mercado. O processo identifica as necessidades do mercado, produto e inteligência tecnológica, suportando as iniciativas de planejamento e facilitando a comunicação entre as funções técnica e comercial. (PHAAL, 2001a).

O método de technology roadmapping (TRM) tem sido amplamente utilizado em empresas e universidades, mundialmente, sendo que a partir de 2000 sua implementação tem crescido significativamente (PROBERT, 2009a). No Brasil, o uso de technology roadmaps para planejamento também tem sido crescente (MERQUIOR, 2007)

O aumento da população mundial e incremento da renda são direcionadores básicos para o aumento da demanda energética nos próximos anos. A empresa British Petroleum estima que no período entre 2010 e 2030 a demanda energética mundial crescerá 39\% (BP, 2012). A matriz energética mundial deverá ser alterada, com um aumento de importância do gás natural e de fontes renováveis de energia. Estas incluem os biocombustíveis, assim como obtenção de energia através de geradores eólicos e células fotovoltaicas (EUROPEAN COMMISSION, 2012).

A produção de biocombustíveis tem sido defendida como uma necessidade para a obtenção de fontes previsíveis de energia, ou como alternativa à escassez 
e aumento de custo de petróleo, além das evidências de aumento do aquecimento global sob influência da queima de combustíveis fósseis. Atualmente, os tipos principais de biocombustíveis utilizados são o bioetanol e biodiesel. Também foram mapeados os biocombustíveis mais promissores em desenvolvimento (NEXANT, 2006), onde o biobutanol é apresentado como uma das alternativas.

O etanol é adotado largamente como biocombustível no Brasil, sendo que os motores e infraestrutura já estão adaptados a este produto. Diversos outros países, contudo, só recentemente formataram suas legislações para adoção de biocombustíveis. Nestes casos, o etanol possui algumas propriedades não ideais, como por exemplo sua afinidade pela água, o que torna custoso o processo de destilação e dificulta seu transporte por tubulações. Além disso, é corrosivo e evapora facilmente. Estas são algumas das razões que fizeram empresas como British Petroleum e Du Pont estudarem a conversão de usinas de etanol a butanol (FORGE, 2007).

A produção de butanol a partir de fontes renováveis já foi utilizada em larga escala no passado. O processo de fermentação anaeróbica para produção de acetona, butanol e etanol através da fermentação ABE (Acetone-butanol-ethanol) é conhecido há mais de 100 anos e foi muito utilizado desde o início do século XX. Porém sofreu declínio em favor de rotas petroquímicas a partir de 1950, em função do custo de produção (NEXANT, 2006a). Atualmente, diversas linhas de pesquisa buscam o aperfeiçoamento do processo biológico para a produção de biobutanol como combustível renovável.

O Departamento de Energia Norte Americano (DOE) publicou uma aplicação do mapeamento tecnológico para caracterização de um segmento de pesquisa no setor de biocombustíveis, em específico para bioetanol (DOE, 2006). Este serve de base para a elaboração de um estudo sobre o potencial de outros biocombustíveis, como o butanol, verificando seu mercado potencial, suas vantagens, e as tecnologias necessárias para a viabilização de seu uso.

O technology roadmapping tem sido utilizado para definir estratégias em longo prazo e a agenda de pesquisa para o desenvolvimento de biocombustíveis. $\mathrm{O}$ 
biobutanol é um dos biocombustíveis em destaque, integrado ao conceito de biorrefinarias (NSF, 2008; CGEE, 2010a).

O conceito de biorrefinarias é estudado pelas usinas de cana-de-açúcar como possível diversificação de seus negócios, de maneira a compensar oscilações no mercado internacional de açúcar e sazonalidade das safras de cana-de-açúcar. Empresas do segmento de madeira, celulose e papel também buscam novas fontes de receitas. A produção e comercialização de produtos químicos, biocombustíveis e energia é apontada como uma alternativa viável. Pode-se empregar processos alcoolquímicos, bioquímicos ou térmicos. Em especial, o aperfeiçoamento da tecnologia de hidrólise poderia converter a celulose de resíduos agrícolas ou florestais em açúcares que podem ser fermentados (AF\&PA, 2010; FOELKEL, 2012; THORP, 2008)

O presente trabalho propõe o uso do technology roadmapping como uma técnica para o planejamento estratégico para o desenvolvimento do biobutanol. São verificadas as oportunidades, alinhando os objetivos de longo prazo com os recursos, linhas de financiamento, e prioridades para o processo de desenvolvimento deste produto no Brasil.

O trabalho está estruturado nos seguintes capítulos:

- Objetivos da Pesquisa: definição do foco e resultados esperados para o trabalho.

- Revisão Teórica: capítulo dividido basicamente em duas partes.

- A primeira parte é dedicada à revisão da metologia do technology roadmapping, comparando os processos descritos por diferentes autores e os respectivos benefícios da aplicação do mapeamento. Ainda nesta fase, são revisados os principais exemplos de roadmaps utilizados em diferentes locais do mundo, principalmente para a definição de políticas públicas e oportunidades tecnológicas para o setor de energia em longo prazo. Na parte final da revisão de roadmaps são visitados os principais estudos realizados no Brasil, com foco no setor de bioenergia. Incluem-se ai alguns estudos que já contemplam o biobutanol. 
- A segunda parte é dedicada ao estudo da tecnologia existente para a produção de biobutanol. São revisadas as principais rotas previstas para obtenção do produto, e as principais variáveis de processo. São identificadas as barreiras ao amplo desenvolvimento e adoção da tecnologia. Também é revisada a adequação do uso de biobutanol como combustível, e sua integração ao conceito de biorrefinarias.

- Desenvolvimento do projeto de pesquisa: descreve como foi estruturado o projeto de pesquisa, em sua fase teórica, revisão de literatura, preparação do questionário, e condução das entrevistas com especialistas do setor.

- Pesquisa de campo: aborda o universo de pesquisa escolhido e descreve a etapa de realização das entrevistas.

- Roadmap para o Biobutanol: este capítulo relata a pesquisa em si, com a descrição e análise das respostas obtidas durante as entrevistas de campo. Os resultados estão agrupados nas categorias de produtos, mercados e tecnologias, conforme o processo de roadmapping proposto por PHAAL (2001a). Neste capítulo é apresentado o roadmap proposto para o biobutanol no Brasil, elaborado a partir das informações coletadas com os especialistas.

- Conclusões: são comentadas as conclusões obtidas a partir do processo de roadmapping. O processo em si é uma oportunidade de aprendizado sobre um determinado tema, sendo possível propor cenários para o desenvolvimento de biobutanol no Brasil, seja como um interessante produto para a pauta de exportações, seja como uma potencial fonte de diversificação para usinas, complementar à produção de bioetanol. São também apontadas sugestões de estudos futuros.

- Apêndice A: é reproduzido o questionário utilizado para condução das entrevistas com especialistas do setor de butanol, roadmaps e bioenergia.

- Referências bibliográficas utilizadas estão listadas ao final do trabalho. 


\section{Objetivo da Pesquisa}

O presente trabalho apresenta o estudo de caso com uso da metodologia do technology roadmapping para identificação de necessidades e oportunidades no setor de biocombustíveis, destacando o biobutanol.

O objetivo geral desta pesquisa consiste em prospectar as oportunidades e necessidades tecnológicas para o biobutanol no cenário brasileiro de biocombustíveis, identificando diferenciais competitivos, econômicos e oportunidades para pesquisa e sustentabilidade do biocombustível brasileiro, em longo prazo.

Objetivos específicos:

- Estudar, diagnosticar e mapear as principais necessidades não atendidas da cadeia de valor do biobutanol no setor de biocombustíveis, identificando as vantagens competitivas em relação a outros tipos de produtos, em especial o bioetanol.

- Mapear as linhas tecnológicas de desenvolvimento, apontando direções para futuras inovações, utilizando as ferramentas da metodologia technology roadmapping (TRM), e adaptando este método ao presente estudo.

- Identificar oportunidades para recursos típicos do Brasil, como utilização das culturas de cana-de-açúcar ou de eucalipto para produção de biobutanol. 


\section{Revisão Teórica}

\section{Parte A: Technology Roadmaps}

\section{1 - Perspectiva Histórica}

Techhnology roadmapping é uma técnica que vem ganhando importância para o planejamento estratégico em longo prazo. Ela considera o alinhamento de mercados, produtos, e tecnologias ao longo do tempo para atingir necessidades específicas (LOUREIRO, 2010a). A metodologia suporta o gerenciamento e planejamento tecnológico, sendo especialmente importante para explorar e comunicar interações entre os recursos, objetivos organizacionais e mudanças no ambiente competitivo (PHAAL, 2004a).

COUTINHO (2004) faz uma revisão da evolução da estratégia da inovação tecnológica na indústria desde da década de 1950. Inovação tecnológica neste contexto foi definida como o processo interativo iniciado pela percepção de uma oportunidade em um novo mercado, levando à implementação de atividades de desenvolvimento, produção e comercialização que garantem o sucesso de uma dada invenção. A estratégia de inovação tecnológica envolve uma análise do ambiente interno e externo à empresa, e a identificação de tendências dos negócios em que a empresa está envolvida. Deve-se identificar as competências existentes e o estágio tecnológico em que a empresa se encontra, podendo-se utilizar roadmaps como ferramenta. Em seguida é feito o levantamento das oportunidades tecnológicas existentes, a seleção e priorização das mesmas.

A Motorola foi uma das primeiras empresas a utilizar o método de technology roadmap (WILLYARD e McCLEES, 1987). O roadmap clássico da Motorola descreve a evolução do rádio para carros, os atributos do produto e as tecnologias necessárias para disponibilizá-los. Além de construir o roadmap em si, a Motorola integrou-o como parte do conhecimento corporativo e sistemas de gerenciamento de negócios, suportados por programas de computador e sistemas integrados de decisão (BERGELT, 2000). A partir deste exercício pioneiro, muitas empresas, governos e instituições passaram a estudar e utilizar a técnica como recurso de planejamento estratégico. 
Um dos maiores atributos da técnica de technology roadmapping é a flexibilidade, permitindo sua customização para adaptá-la às diferentes organizações e diferentes tipos de objetivos estratégicos (LEONG e CHENG, 2010). Diversos autores sugerem processos com etapas para condução dos roadmaps. O ponto em comum em todos eles é permitir a adaptação da metodologia à realidade e necessidades da organização que a promove, a fim de atingir os objetivos propostos.

Technology roadmapping foi definido por GARCIA e BRAY (1997) como o planejamento de tecnologia baseado nas necessidades, que ajuda a identificar, selecionar, e desenvolver alternativas de tecnologias para atender às necessidades de desenvolvimento de produtos e recomendar sua adequabilidade no ambiente intensamente competitivo. Estes benefícios estão resumidos abaixo:

- Identificação de necessidades críticas de produto que irão direcionar a seleção de tecnologia e desenvolvimento de decisões.

- Determinar as alternativas de tecnologias que podem satisfazer as necessidades críticas do produto.

- Selecionar as alternativas de tecnologia adequadas.

- Gerar e implementar um plano para desenvolver e aplicar as alternativas de tecnologia selecionadas.

De acordo com ALBRIGHT (2002a), alguns benefícios dos roadmaps incluem os seguintes pontos:

- correlacionar inovações e aplicações com decisões de pesquisa e tecnologia.

- revelar deficiências em planos de pesquisa e inovação.

- priorizar investimentos, baseados nos objetivos finais.

- estabelecer objetivos mais competitivos e realistas.

- comunicar os planos de inovação aos membros do time, investidores e apoiadores.

- propiciar a visualização e reagir sobre eventos que requeiram mudança de direção. 
O termo technology relaciona-se à aplicação da ciência para resolver problemas no desenvolvimento, mercado, concorrência e desempenho (WILLYARD e McCLEES, 1987). O termo roadmapping descreve a técnica ou processo para aplicar a metodologia, ou como as diferentes atividades são organizadas, envolvendo participantes, fluxo de informação, ferramentas, e ambiente organizacional. O roadmap corresponde ao resultado final, na forma de um mapa resumido gerado ao final do processo (OLIVEIRA e ROZENFELD, 2009).

O método correlaciona as prioridades entre mercado, produto e parâmetros tecnológicos e detecta os fatores relacionados a eles (KAPPEL, 2001). Portanto, o uso da técnica de technology roadmapping torna possível o alinhamento de investimentos e organiza o uso correto dos recursos para atingir os objetivos desejados. Isto permite que as tecnologias apropriadas estejam disponíveis no tempo adequado, para fazer os produtos que serão necessários naquele momento.

Trabalhos publicados no Brasil têm utilizado os termos planejamento tecnológico (DRUMMOND, 2005), mapa ou mapeamento tecnológico (CGEE, 2010a, DIDIO, 2011), roadmap tecnológico (CORTEZ, 2010, COUTINHO e BOMTEMPO 2011), assim como technology roadmapping (LOUREIRO 2010b, OLIVEIRA 2009, OLIVEIRA et al. 2012). No presente trabalho será utilizado em geral o termo technology roadmap ou roadmapping de acordo com o livro "Roadmapping: Uma abordagem estratégica para o gerenciamento da Inovação em Produtos, Serviços e Tecnologias" (OLIVEIRA et al., 2012). Esta publicação em Português foi preparada por pesquisadores brasileiros da Universidade Federal de São Carlos e Universidade de São Paulo, em conjunto com a Universidade de Cambridge.

Dentre os formatos sugeridos para a condução do roadmapping, são possíveis diferentes abordagens. No presente estudo, foram revisadas algumas metodologias citadas com destaque na literatura. A primeira é a metodologia de WILLYARD e McCLEES (1987), e seguida pelos estudos de GARCIA e BRAY (1997), assim como os processos de ALBRIGHT e KAPPEL (2003). Em seguida, 
é explorada em mais detalhes a metodologia de PHAAL e PROBERT (2001b), que foi utilizada para a condução do estudo de caso sobre biobutanol.

WILLYARD e McCLEES (1987) descreveram inicialmente um processo onde os seguintes aspectos eram estudados: descrição da oportunidade, previsão das tecnologias necessárias, posicionamento em termos de qualidade e tecnologia, disponibilização de recursos, mapeamento da propriedade intelectual, descrição do produto, relatórios de posicionamento, e relatório final com o mapa tecnológico.

GARCIA e BRAY (1997) efetuaram um estudo para sistematização do processo de roadmapping. Segundo estes autores, até aquele momento, o foco era no produto e não no processo em si. Foi ressaltada a efetividade do roadmapping para obtenção de informações para melhores decisões quanto a investimentos em pesquisa e desenvolvimento voltados a tecnologias críticas: qual rota seguir, em qual prazo a tecnologia será necessária, ou a urgência de obtenção de tecnologias em paralelo. As etapas propostas estão descritas na FIGURA 1:

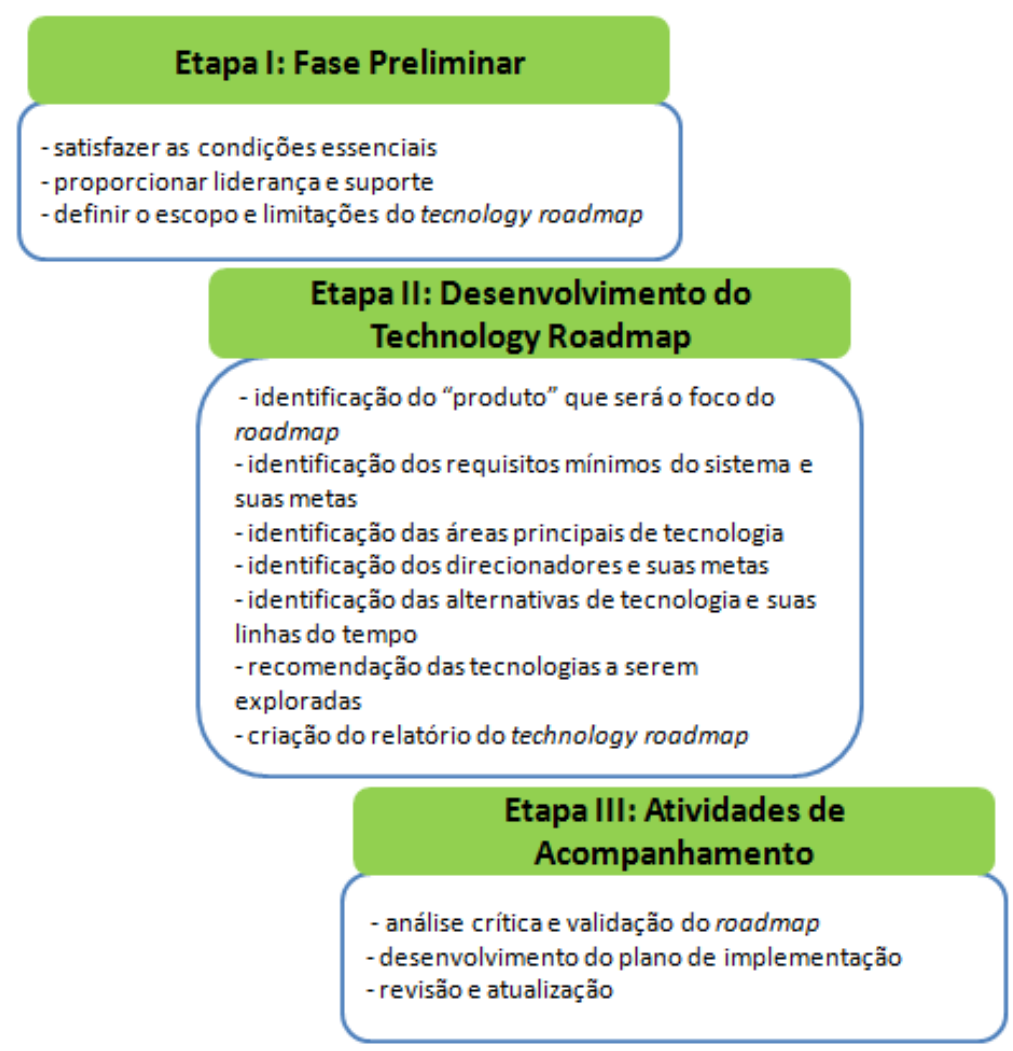

FIGURA 1: Processo de roadmapping (adaptado de GARCIA e BRAY 1997). 
O principal objetivo da Etapa I é a identificação de que existe uma oportunidade e que o roadmap pode auxiliar na busca de soluções. Nesta etapa são alocados os recursos e estabelecido o suporte organizacional para possibilitar o trabalho multidisciplinar entre diversos departamentos da empresa. Na Etapa II desenvolve-se o exercício em si, e os sete passos consecutivos levam à criação do documento. A Etapa III incorpora uma revisão e análise crítica, com o objetivo principal de verificar se o documento gerado responde às perguntas e necessidades identificadas inicialmente. Outro importante ponto incorporado é a necessidade de atualização periódica, visto que as tecnologias e cenário competitivo continuam a evoluir.

KAPPEL (2001) sugeriu uma taxonomia relacionando o objetivo ou ênfase do roadmap, seja na detecção de tendências ou posicionamento, com a proposta do roadmap, para os níveis industrial ou corporativo, conforme a FIGURA 2:

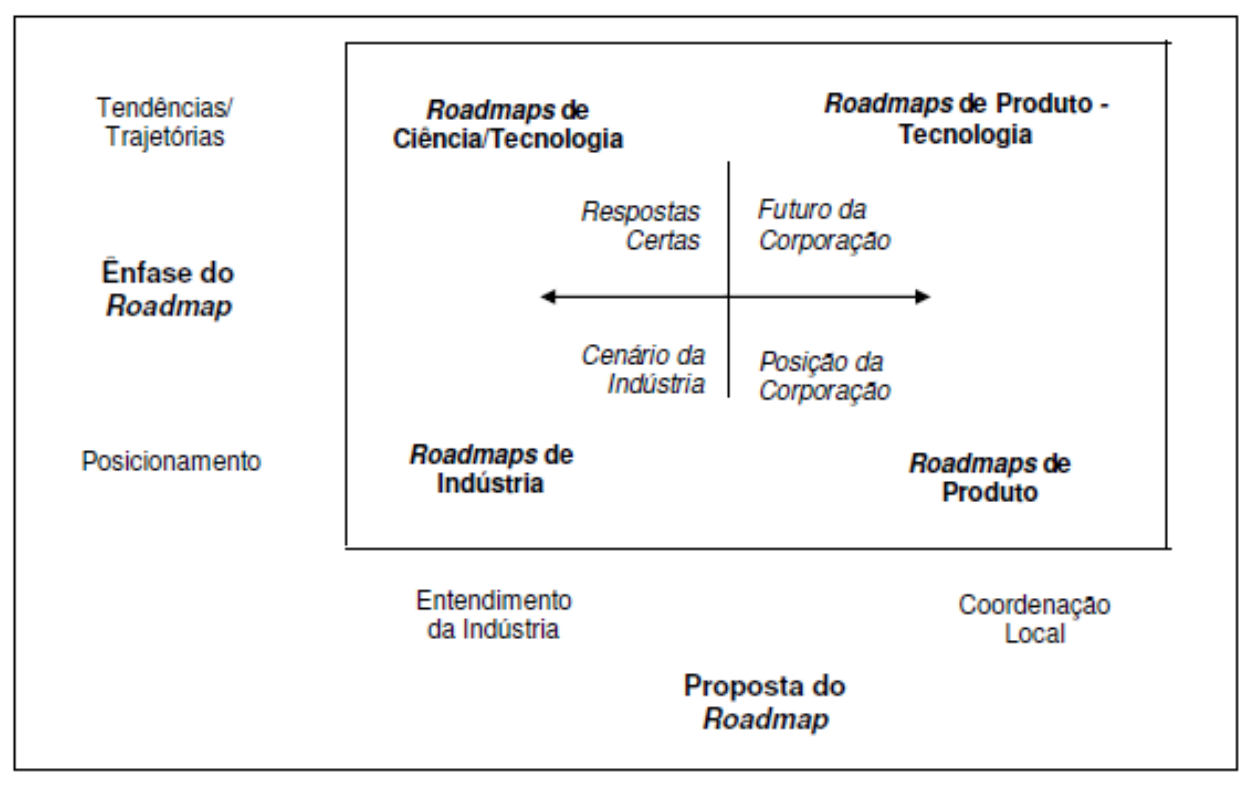

FIGURA 2: Taxonomia proposta para um roadmap, correlacionando sua ênfase e proposta (KAPPEL 2001 apud LOUREIRO 2010b)

Desta maneira, são observadas quatro possibilidades para aplicação dos roadmaps:

- Ciência e Tecnologia: objetivam o entendimento de aplicações futuras, identificando tendências, efetuando prognósticos, e sugerindo metas para o desenvolvimento do setor; 
- Produto e Tecnologia: correlacionam as decisões de desenvolvimento de produto com as tendências de tecnologia e de mercado para uma empresa;

- Produto: posicionam as tendências ao longo do tempo para a evolução de um determinado produto de uma empresa;

- Indústria: estabelece as metas de desenvolvimento da tecnologia com os parâmetros de custo e desempenho para a competitividade do setor.

ALBRIGHT e KAPPEL (2003) descreveram uma metodologia organizada em sessões dedicadas ao estudo do mercado, tecnologia, e mapa de planejamento. Estes passos incluem a descrição da empresa e de seus concorrentes. Esta metodologia estabelece os passos para a criação de um roadmap nas áreas de tecnologias altamente baseadas em ciência, conforme 0 QUADRO 1.

\begin{tabular}{|c|l|}
\hline Tópico & Objetivo \\
\hline $\begin{array}{l}\text { 1. Elementos de Ciência e } \\
\text { Tecnologia }\end{array}$ & Definem o escopo do trabalho. \\
\hline 2. Aplicações da Tecnologia & $\begin{array}{l}\text { Quando e como as tecnologias se } \\
\text { tornarão inovações a serem utilizadas. }\end{array}$ \\
\hline 3. Arquitetura & $\begin{array}{l}\text { Como os elementos interagem e se } \\
\text { complementam. }\end{array}$ \\
\hline 4. Desafios & $\begin{array}{l}\text { Objetivos e métricas de desempenho } \\
\text { para as tecnologias. }\end{array}$ \\
\hline 5. Tendências e Descontinuidades & $\begin{array}{l}\text { Tendências de crescimento e e } \\
\text { desempenho, curva de aprendizado e } \\
\text { potenciais interferências. }\end{array}$ \\
\hline 6. Evolução da Tecnologia & Ocentro do roadmap tecnológico. \\
\hline 7. Posicionamento Técnico da & $\begin{array}{l}\text { Abordagem dos concorrentes aos } \\
\text { Cosafios. Tecnologias alternativas. }\end{array}$ \\
\hline 8. Plano de Ação & $\begin{array}{l}\text { Estratégia tecnológica, recursos e } \\
\text { prazos para os investimentos em } \\
\text { tecnologia. }\end{array}$ \\
\hline
\end{tabular}




\begin{tabular}{|l|l|}
\hline $\begin{array}{l}\text { 9. Propriedade Intelectual e } \\
\text { Padronização }\end{array}$ & $\begin{array}{l}\text { Necessidades e barreiras, com as } \\
\text { ações necessárias para obter acesso } \\
\text { ou proteger a informação. }\end{array}$ \\
\hline 10. Mapa de Investimento & \begin{tabular}{l} 
Prioriza os investimentos em tecnologia \\
\hline 11. Mapa de Risco
\end{tabular} \\
& $\begin{array}{l}\text { Indicadores de risco dos planos. } \\
\text { gatilhos para mudanças. }\end{array}$ \\
\hline
\end{tabular}

QUADRO 1: Elementos de um Roadmap em Ciência e Tecnologia (adaptado de ALBRIGHT e KAPPEL (2003)

3.2 - O processo de construção do mapa tecnológico segundo PHAAL (2001b)

Robert Phaal e David Probert, da Universidade de Cambridge, (CTM, 2012) elaboraram um processo de sistematização dos roadmaps denominado T-Plan, ou Technology Plan. Esta padronização permite uma abordagem de implementação rápida por empresas, sendo denominada "fast start" (PHAAL, 2001b). Três questões básicas são envolvidas nesta abordagem do technology roadmapping conforme proposto abaixo:

- Onde queremos estar no futuro?

- Onde estamos hoje?

- Como chegaremos a este destino final?

O processo de construção do mapa deve ser considerado como uma oportunidade de aprendizado sobre um determinado tema. $\mathrm{O}$ documento final deve permitir a visualização dos mercados ao longo de um período de tempo, dos produtos necessários para satisfazer a estas necessidades de mercado, e as tecnologias necessárias para criar ou desenvolver estes produtos. O processo sugere a necessidade de coletar e analisar informação, interagir com especialistas no assunto, e definir a estratégia final (PHAAL, 2001a).

O T-Plan foi desenvolvido como ferramenta de apoio a profissionais interessados no desenvolvimento e comunicação do planejamento de produtos em suas organizações. A abordagem foi elaborada inicialmente para empresas de 
manufatura, podendo ser adaptada a outros contextos, tanto em pequenas empresas quanto em grandes corporações.

O roadmap elaborado pode ter várias formas, porém, como linha geral, inclui as perspectivas comerciais e tecnológicas e os parâmetros tecnologia, mercado e produtos, sempre visualizados ao longo do tempo, conforme a FIGURA 3.

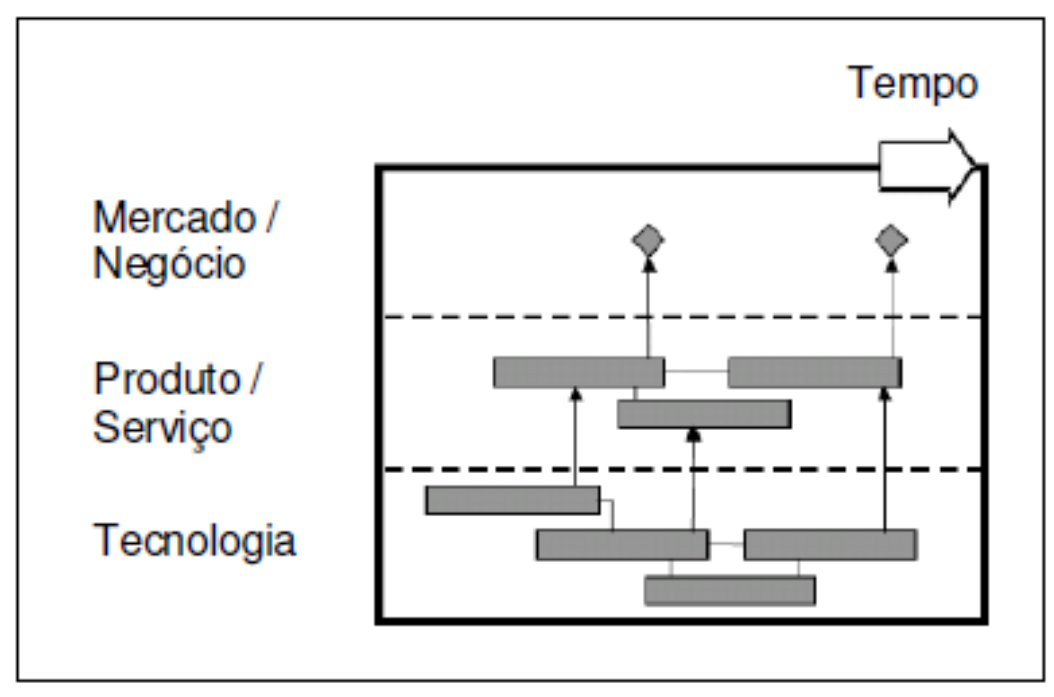

FIGURA 3: Representação ilustrativa de um technology roadmap (PHAAL 2001a, apud LOUREIRO 2010b).

O processo de criação do roadmap é um processo interativo onde, em geral, é reunido um grupo de especialistas. O processo é muito rico pois as opiniões individuais são elaboradas e os conceitos são ampliados após ciclos de discussão e captura de ideias. A preparação prévia envolve obtenção de informações secundárias, dados de mercado, estudos de patentes e análise da concorrência. $O$ processo pode ser conduzido através de uma série de seminários (ou workshops), a saber (FIGURA 4): o seminário de mercado, o seminário de produto, o seminário de tecnologia, e o seminário para criação do mapa final. Não existe um período de tempo estabelecido para cada seminário, sendo que cada um pode ser conduzido em períodos tão curtos quanto uma manhã, ou períodos mais longos, dependendo da complexidade do tema (LEAL, 2012). 


\section{Processo Padrão: 4 Etapas (Phaal, 2009a)}

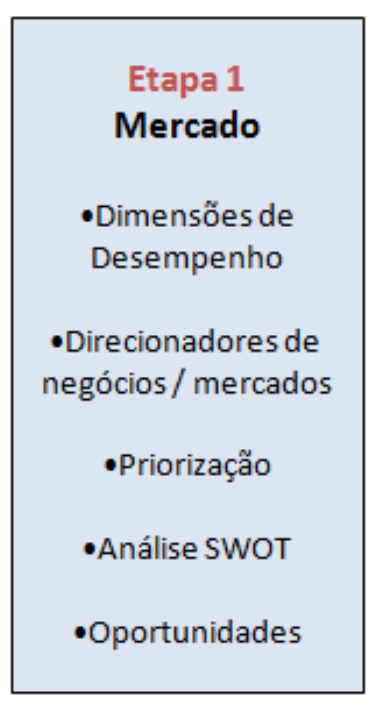

Estabelecendo o processo
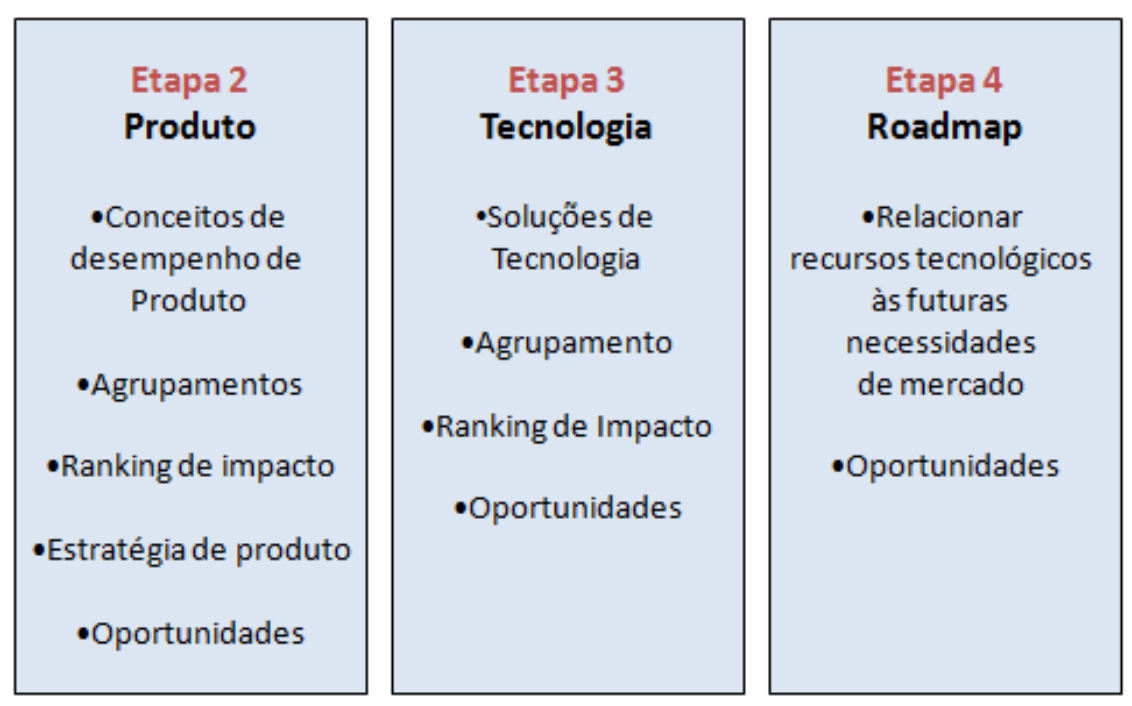

Gerenciando
o processo
Progredindo a partir do processo

FIGURA 4: Série de seminários propostos por Phaal (adaptado de PHAAL, 2009a)

Antes do primeiro seminário, são necessárias atividades de planejamento. $\mathrm{Na}$ fase de preparação são definidos o objetivo e premissas do projeto, o facilitador, o compromisso da alta liderança, o prazo e os recursos disponíveis ao processo. As principais ações nesta etapa incluem (a) definição da necessidade do negócio e da empresa na aplicação do método, (b) obtenção do suporte da alta gerência para a condução do processo, incluindo recursos financeiros necessários (c) definição dos participantes, obtendo seu compromisso e disponibilidade, (d) contratação de facilitador e especialistas externos, se necessário (e) elaboração do cronograma, (f) levantamento das informações de apoio relevantes, tais como plano estratégico de negócios, estudos de mercado, relatórios de tecnologia, (g) definição do escopo e foco da unidade de análise ( $h$ ) definição do horizonte de tempo esperado para o estudo (i) definição do tipo de mapa e arquitetura esperados no final dos trabalhos (IBARRA GONZÁLES, 2007). 
Durante o primeiro seminário, as cadeias de valor do negócio e mercado são identificadas. É uma oportunidade para rever as estratégias da empresa, alinhadas às tendências do mercado. São identificados direcionadores (drivers) de mercado e negócio em relação ao futuro. Os direcionadores definem a motivação da organização para desenvolver produtos e serviços. Estabelecem também a priorização das características dos produtos ou serviços, e clarificam a contribuição das tecnologias. As principais atividades nesta etapa são portanto (DIDIO, 2011):

- Levantamento e revisão do objetivo geral e dos objetivos específicos;

- Determinação das metas e indicadores dos objetivos;

- Levantamento dos requisitos do mercado;

- Seleção dos produtos e tecnologias prioritárias;

- Identificação do conjunto de dimensões de funcionalidade e desempenho dos produtos;

- Identificação dos direcionadores de mercado e negócio;

- Elaboração de análise SWOT para apoiar o plano estratégico;

- Identificação das lacunas em conhecimento e tecnologia para trabalhos futuros necessários.

No segundo seminário, dedicado ao produto, há uma revisão das características dos produtos existentes ou em desenvolvimento, correlacionados aos direcionadores identificados no seminário anterior, e definição de sua relevância. São investigadas as relações entre as características do produto e os direcionadores, identificando-se um grau de impacto. Isto definirá a estrutura através da qual a evolução dos produtos pode ser explorada, através das opções de tecnologia estudadas no seminário seguinte (DIDIO, 2011). As atividades a serem desenvolvidas neste seminário são:

- Identificação das características dos produtos e serviços para atender aos direcionadores do mercado e negócio;

- Classificação do valor potencial das características de produtos e serviços quanto ao impacto dos direcionadores; 
- Consideração das estratégias de produto alternativas para satisfazer o conjunto de direcionadores de mercado e negócio no futuro;

- Identificação das lacunas em conhecimento e áreas para trabalhos futuros necessários.

As tecnologias são avaliadas em um terceiro seminário específico. São avaliadas as evoluções tecnológicas, o progresso que devem atingir e as características de produto desejadas, satisfazendo as necessidades e tendências do mercado. São avaliadas também as competências, qualificações, os recursos financeiros e parcerias estratégicas (DIDIO, 2011). Portanto, no terceiro seminário deve-se:

- Identificar as soluções tecnológicas para atender às características de produto levantadas;

- Classificar o valor potencial das soluções tecnológicas em termos de impacto nas características de produto;

- Identificar as lacunas em conhecimento e áreas para trabalhos futuros necessários.

O seminário final é dedicado a agrupar a informação e a elaborar um mapa dependente do tempo para o planejamento estratégico de produtos, identificando oportunidades oriundas das tecnologias disponíveis (PHAAL, 2001b). Em resumo, este processo permite a definição do planejamento estratégico (S-Plan). Através do plano tecnológico ( $T$-Plan) torna-se possível atingir as inovações ou desenvolvimentos de novos produtos (PHAAL, 2009b). As fases anteriores subsidiam a construção do mapa final (DIDIO 2011). O seminário final inclui as seguintes etapas:

- Desenvolvimento de um mapa preliminar

- É definido o formato do roadmap incluindo o horizonte de tempo considerado. Pode-se considerar o planejamento em anos ou horizonte temporal de curto, médio ou longo prazo, incluindo as gerações de produtos a serem desenvolvidas;

- A estratégia de desenvolvimento de produto pode ser definida em termos de plataformas ou ciclos de desenvolvimento de 
produtos. É importante identificar se as inovações necessárias são incrementais ou disruptivas;

- A evolução das tendências do mercado é registrada, destacando-se eventos que tenham relevância no desenvolvimento do produto ou tecnologia, como barreiras legais, lançamento de novos produtos, ou ações da concorrência (início de operações de uma nova fábrica, por exemplo);

- Deve-se apontar desafios e possíveis barreiras à implementação do mapa conforme definido;

- Identificação das lacunas em conhecimento e áreas para trabalhos futuros necessários.

- Identifica áreas onde trabalho complementar é necessário, incluindo atuação sobre processos, regulamentações, concorrência, qualificações, recursos e tecnologia;

- Identifica fontes de informação e sistemática de comunicação, implementação e revisão do roadmap;

Os roadmaps podem ser desenvolvidos utilizando dois conceitos de direcionamento de tecnologia. O primeiro conceito é o "requerido pelo mercado" (market pull), no qual os requisitos do consumidor são estudados e detectadas as tecnologias necessárias para que as empresas atendam mercados futuros. Já o conceito "impulsionado pela tecnologia" (technology push), explora as inovações tecnológicas que podem resultar em novas oportunidades de negócios, construindo uma visão de futuro para a empresa (PHAAL, 2009a; SOUZA, 2010).

O formato do roadmap é flexível. Sua estrutura e o processo para desenvolvê-lo podem ser adaptados, de acordo com diferentes contextos estratégicos e de inovação. Esta escolha depende das necessidades individuais da organização que o promove. Ele pode ser visto como um quadro dinâmico de negócios, onde o desenvolvimento e evolução de um negócio e seus componentes podem ser explorados, mapeados e comunicados (PHAAL, 2004b). Alguns formatos de roadmaps são exemplificados na FIGURA 5 (PHAAL, 2001a). 


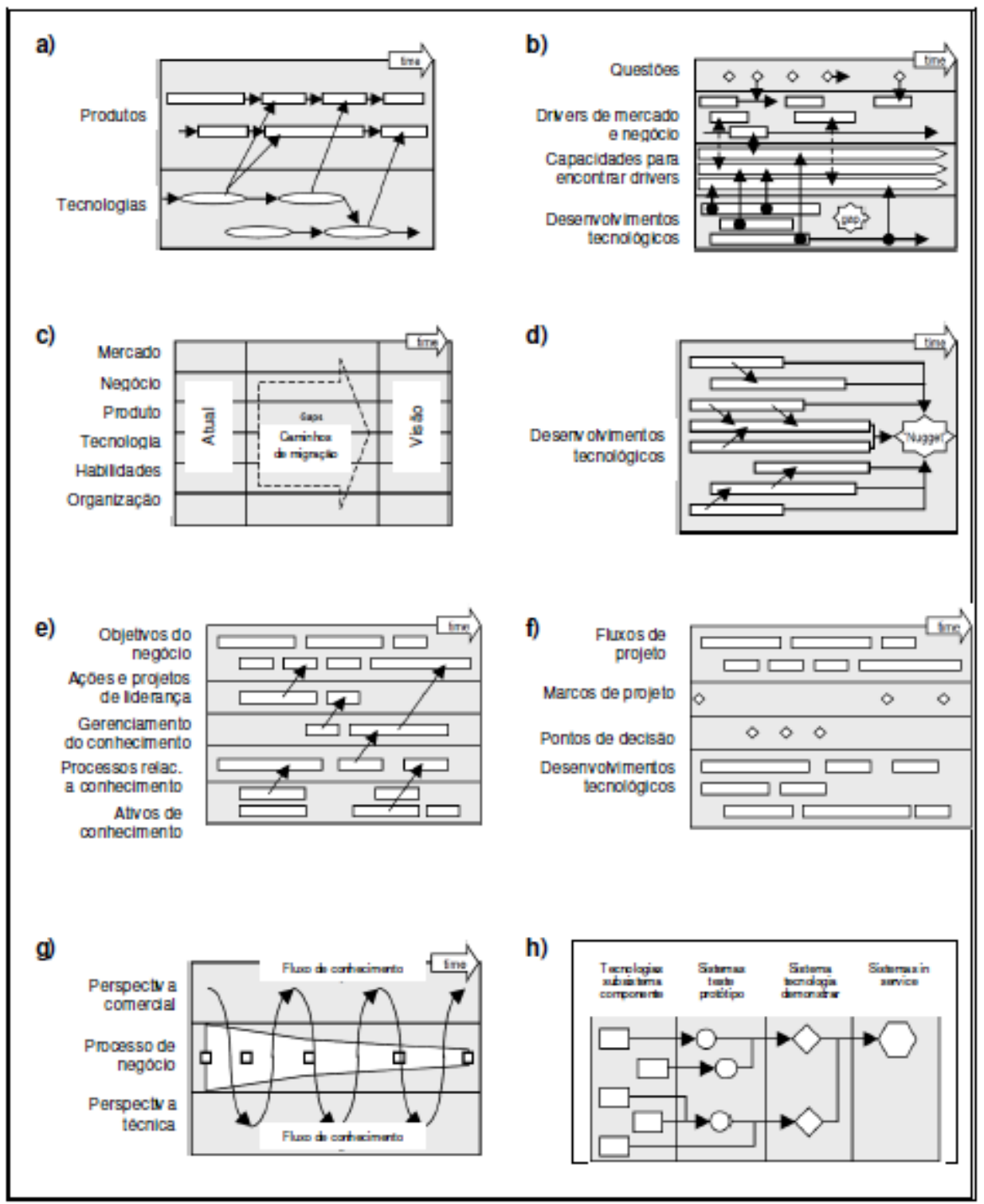

FIGURA 5: Tipos de roadmaps que podem ser utilizados para estudo de a) produto, b) serviço / capacidade, c) estratégia, d) longo prazo, e) ativos de conhecimento, f) programa, g) processo, h) integração. Fonte: adaptado de PHAAL 2001a, apud LOUREIRO 2010b.

Estes tipos tradicionais de roadmap podem ser descritos conforme a seguir:

a) Planejamento de Produto: é o tipo mais comum de technology roadmap, estudando a inserção de tecnologia em produtos. Geralmente, envolve mais de uma geração de produtos. 
b) Planejamento de Serviço ou Capacidade: similar ao caso anterior, porém mais adequado a empresas de serviços. Focado em determinar como a tecnologia suporta as capacidades organizacionais.

c) Planejamento Estratégico: inclui uma dimensão estratégica, permitindo a avaliação de diferentes oportunidades ou ameaças, geralmente dentro de um negócio. As oportunidades são identificadas através da comparação da visão futura com a posição atual. São avaliadas oportunidades estratégicas para superar as lacunas.

d) Planejamento em longo prazo: o prazo de tempo para avaliação é estendido, sendo geralmente utilizado para um setor ou em nivel nacional (foresight).

e) Planejamento de ativos de conhecimento: permite o alinhamento das iniciativas do conhecimento existente ou do gerenciamento do conhecimento, com a unidade de negócio.

f) Planejamento de Programa: relacionado à implementação da estratégia, e mais diretamente relacionado ao planejamento de programas, por exemplo, em pesquisa e desenvolvimento.

g) Planejamento de Processos: proporciona o gerenciamento do conhecimento, em geral focando em uma área específica do processo em particular. Bastante aplicado ao desenvolvimento de novos negócios.

h) Planejamento da Integração: descreve o planejamento ou integração da tecnologia, descrevendo como diferentes tecnologias combinam-se em produtos ou sistemas, formando novas tecnologias. Estes tipos de roadmaps não necessariamente incluem a linha de tempo.

Estudos de LEE e PHAAL (2011) revelaram que a utilização dos roadmaps é influenciada pelo uso de softwares adequados para sistematização da busca e organização das informações, por um processo de roadmapping efetivo, suporte organizacional, e alinhamento com os objetivos da empresa. Todos estes fatores têm influência positiva para a continuidade do uso da técnica de roadmapping, e aumentam o desempenho em pesquisa e desenvolvimento. DIDIO (2011) desenvolveu uma metodologia para dar apoio ao planejamento estratégico, utilizando technology roadmaps associados com a aplicação do processo de detecção de fontes emergentes de pesquisa em bases de dados de artigos 
científicos e de patentes. O uso de pesquisa de patentes pode aumentar a objetividade e representatividade de um technology roadmap. Através de ferramentas como prospecção de textos (text-mining) e análise de redes, é possível sistematizar a informação extraída de bancos de dados (LEE et al., 2009).

\section{3 - Benefícios do mapeamento tecnológico}

O processo de construção do mapa tecnológico serve como uma ferramenta de diálogo para obter uma visão comum dos participantes do processo. Esta atividade geralmente é conduzida da forma presencial, fomentando as discussões. $O$ processo de roadmapping favorece a interação social dos participantes, que elaboram e desenvolvem conhecimento através de um ambiente propício para cogitar, articular e comunicar ideias (KERR, PHAAL e PROBERT, 2012). O roadmap também é um importante veículo para comunicação dos resultados, conclusões, e sugestões do estudo para a organização. A comunicação efetiva é crucial para a credibilidade do documento, assim como sua aceitação pela organização e consequentemente sua utilidade como um todo (LEE e KIM, 2012).

Cada fase do processo de mapeamento tecnológico pode utilizar diferentes ferramentas e técnicas para a condução dos trabalhos. PROBERT (2009a e 2009b) utilizou ferramentas como análise SWOT, ou seja, pontos fortes, deficiências, oportunidades e ameaças (strenghts, weaknesses, opportunities and threats), análise do ambiente (PEST - político, econômico, social e tecnológico), scorecards, análise de portfólio, cinco forças de Porter (PORTER, 2008), arranjos produtivos locais (PORTER, 1998), representações gráficas e figuras, análise de cadeia de valor e valoração de tecnologias e projetos. Uma série de pesquisas já publicadas podem ser consultadas para estudo e melhor desenvolvimento de novos mapas. PHAAL (2009c) disponibiliza uma lista de aproximadamente 300 artigos de referência sobre roadmaps.

Um estudo recente realizado por CARVALHO et al. (2013), revisou artigos publicados entre 1997 e 2011 principalmente nas revistas Technological Forecasting and Social Change e Research-Technology Management. Foi 
verificado que grande parte dos artigos utilizava metodologia de pesquisa qualitativa, indicando que grande parte da pesquisa ainda está em fase exploratória. Também foi verificada a necessidade de maior integração entre o roadmap e outras ferramentas do processo de inovação, como o gerenciamento do conhecimento, e a comunicação efetiva.

Os roadmaps podem ser adaptados para satisfazer objetivos específicos (LEE, 2005). O uso de roadmaps para uma única linha de produtos ou uma única unidade de negócios em geral representa baixa complexidade. O exercício tornase mais complexo quando são estudadas diferentes unidades de negócio, pois fatores como tempo de vida de produto, base de clientes, e cenário competitivo podem mudar de uma unidade a outra. COSNER et al. (2007) estudou a arquitetura dos roadmaps para suprir tal necessidade.

A integração dos mapas tecnológicos ao gerenciamento de portfólio foi proposta por OLIVEIRA e ROZENFELD (2010). Os autores defenderam seu uso na fase inicial do desenvolvimento de novos produtos em frentes emergentes de pesquisa. Foi sugerida a adoção de um método baseado em technology roadmaps denominado ITG, para o planejamento estratégico do portfólio de produtos. Foram estabelecidas 13 etapas neste método, com a adoção de ferramentas específicas em cada etapa (OLIVEIRA, 2009). O uso da metodologia de roadmapping foi também defendido por LEE (2008) para a seleção de projetos. O roadmap estratégico de produto é listado por COOPER (2011) como um fator facilitador de inovações ousadas em mercados maduros.

Quando o mapa final é implementado, a organização pode visualizar os passos que devem ser seguidos para o desenvolvimento de maneira que suas tecnologias estejam prontas e disponíveis quando necessário. A dinâmica da implementação do roadmap pode afetar o processo de trabalho estabelecido na organização, assim como sua estrutura e cultura, de maneira a redirecionar os recursos para os projetos (GERDSRI, 2009).

É importante que seja estabelecida uma rotina para revisão periódica e atualização do roadmap frente à evolução da tecnologia, mudanças em necessidades ou ambiente competitivo. ALBRIGHT (2002b) fez uma revisão de um artigo publicado em 1967, com previsões sobre como 100 tecnologias 
deveriam evoluir nos próximos 33 anos a partir daquela data, ou seja, até o ano 2000. O aprendizado sobre o sucesso de predições passadas sobre o estágio atual destas tecnologias levou à conclusão de que é importante a revisão continuada de tendências relativas às tecnologias em foco. Isto permite derivar aplicações mais complexas, onde o declínio dos custos leva a novas inovações, novas possibilidades de contribuições por indivíduos, contribuindo para a sustentabilidade desta tecnologia em longo prazo.

\section{4 - Aplicações em Bioenergia}

Inicialmente aplicados apenas a uma empresa ou departamento, o processo de mapeamento tecnológico tem sido utilizado para estudar segmentos da economia, ou para definir a visão estratégica de um setor para o futuro. Um dos primeiros estudos envolvendo um grupo mais amplo de empresas foi promovido pela Sociedade dos Fabricantes e Revendedores de Veículos no Reino Unido, ao patrocinar um completo estudo em 2002 para o desenvolvimento de veículos nos próximos 20 anos (SMMT, 2004).

Em alguns países, os governos começaram a utilizar a linguagem dos technology roadmaps para informar e promover transições tecnológicas. Enquanto a indústria tende a focar-se no curto prazo e no progresso técnico, os roadmaps públicos e nacionais usualmente consideram objetivos de longo prazo, que envolvem mudanças tecnológicas, sociais e políticas (McDOWALL, 2012).

O Ministério da Economia, Comércio e Indústria do Japão promove os roadmaps para construir relacionamentos colaborativos entre diferentes setores na universidade, indústria e governo (YASUNAGA, 2009). Várias agências em diferentes países suportaram o uso de roadmaps para construir uma visão estratégica de longo prazo, como o caso da Coréia do Sul (KISTEP, 2002), e Japão (ABE, 2009). Naquele país, o uso de roadmaps foi indicado como mecanismo para melhoria do processo de tomada de decisão, descobertas, e oportunidades de inovação, influenciando também na qualidade do plano de negócios. O Ministério da Economia, Comércio e Indústria do Japão propôs o 
strategic technology roadmap (STM) como instrumento para a revitalização de indústrias regionais e de corporações de médio porte.

Na Austrália (AIC, 2011), o Departamento de Inovação, Indústria, Ciência e Pesquisa identificou as principais tecnologias que teriam impacto na ciência e sociedade nos próximos 10 a 15 anos. Foi gerado um roadmap sobre o futuro da nanotecnologia, biotecnologia, e biologia sintética. No Canadá (INDUSTRY CANADA, 2012), o technology roadmapping foi defendido como mecanismo para suportar a indústria local em inovação, competitividade e conquista de novos mercados.

PHAAL (2009d) listou cerca de 1500 roadmaps disponíveis ao público nas areas de química, defesa, energia (elétrica, combustíveis fósseis, células a hidrogênio, nuclear, sustentabilidade de sistemas energéticos), nanotecnologia, ciência (astronomia, agricultura, espacial), software e computação, e indústrias automotiva e de aviação. Baseada neste trabalho, LOUREIRO (2010a) efetuou uma revisão mais detalhada sobre estes documentos de domínio público, classificando-os de acordo com a área efetiva de estudo. Foi concluído que aproximadamente $11 \%$ dos roadmaps estavam ligados à área de energia. Um exemplo da aplicação de roadmaps para a área de energia foi realzado por DAIM (2012) ao estudar o setor de energia eólica. No estudo foram usados como direcionadores os impactos no meio ambiente, o aumento de custo e dependência de combustíveis fósseis, oportunidades de negócios, envolvimento governamental, e disponibilidade de ventos no Noroeste dos Estados Unidos.

AMER e DAIM (2010) estudaram publicações de roadmaps ligados à área de energia renovável. Eles agruparam os estudos em estudos nacionais, estudos de indústria ou setor, e estudos de organizações. Os estudos nacionais geralmente focam em futura segurança energética, dependência energética, formulação de políticas e proteção ambiental. Os estudos da indústria ou setor são utilizados para definir a visão, necessidades comuns, e avaliar barreiras e riscos para a indústria, nos aspectos técnicos, políticos e comerciais. São também utilizados para comunicação com o governo e recomendação de políticas que necessitam ser implementadas para o desenvolvimento de um setor (JEFFREY, 
2012). Já os estudos de organizações buscam a priorização de projetos de pesquisa e desenvolvimento para atingir os objetivos de negócios.

Os Ministros dos países do G8 (Estados Unidos, Canadá, Japão, França, Alemanha, Itália, Rússia e Reino Unido), além de China, Índia e Coréia do Sul, declararam em sua reunião anual em 2008 o seu pedido à Agência Internacional de Energia para que preparasse roadmaps para o avanço inovativo da tecnologia em energia. Esta ação resultou em roadmaps globais cobrindo 19 diferentes tecnologias (IEA, 2010). Um destes estudos, sobre energia hidroelétrica, foi elaborado em cooperação direta com o Ministério de Minas e Energia do Brasil (IEA, 2012).

A Academia Chinesa de Ciências aplicou a metodologia para descrever a rota tecnológica para o desenvolvimento de sua matriz energética até o ano de 2050 (CHEN, 2010). O Centro Britânico de Pesquisas (The UK Research Centre) utilizou os benefícios do roadmap para priorizar atividades de pesquisa e superar obstáculos no conhecimento em bioenergia, assim como influenciar o financiamento da pesquisa, e encorajar o trabalho colaborativo entre grupos de pesquisa acadêmicos e desenvolvedores industriais de tecnologia (KEAYBRIGHT and TAYLOR, 2007). A abordagem do technology roadmapping foi utilizada por BLAIR (2009) para estudar a produção sustentável de biodiesel nos Estados Unidos.

Um grupo de 300 especialistas da indústria, negócios, universidade e governo utilizou o technology roadmapping para estudar as tecnologias de conversão química ou biológica no Canadá, para uso dos recursos biológicos de maneira a preservar o meio ambiente e a qualidade de vida (CANADA, 2005).

A França usou os roadmaps para estabelecer prioridades no desenvolvimento de biocombustíveis de segunda geração. Rotas de conversão termoquímica ou bioquímica de matérias primas lignocelulósicas foram sugeridas para produzir combustíveis em quantidades suficientes para cumprir com a Diretiva Europeia 2003/30/EC que estabelece a meta de uso de um mínimo de 10\% de biocombustíveis até 2020 (ADEME, 2009). 
O Conselho Europeu para Energias Renováveis (EREC, 2007) comparou o crescimento projetado das energias renováveis no período de 2000 a 2020. Foi destacado o papel das biomassas, seja para conversão em combustíveis líquidos, ou queima para geração de eletricidade e calor.

Nos Estados Unidos, começaram a ser estabelecidos objetivos para o desenvolvimento de biocombustíveis após a aprovação do Biomass Research and Development Act of 2000. Alguns objetivos estabelecidos pelo BIOMASS TECHNICAL ADVISORY COMMITTEE (2002), foram:

- Segurança nacional: desenvolvimento de fontes nacionais para reduzir dependência do petróleo.

- Proteção ao meio ambiente: através da redução do uso de combustíveis fósseis e suas respectivas emissões, os biocombustíveis contribuiriam para melhor qualidade do ar e da água. Poderiam também utilizar resíduos de produtos agrícolas até então descartados.

- Crescimento da economia rural: estímulo ao desenvolvimento da economia agrícola, florestal, e indústrias de serviços relacionadas.

Objetivos tecnológicos para o desenvolvimento de etanol celulósico foram estabelecidos nos Estados Unidos baseados em uma série de seminários sobre conversão de biomassa em biocombustíveis. Os principais objetivos foram identificar desafios e barreiras para a rápida expansão da produção de etanol celulósico, e determinar maneiras de acelerar o desenvolvimento de soluções através de recursos da biologia e um direcionamento científico unificado. Uma agenda comum foi definida após a revisão em detalhes da tecnologia atual, e o estabelecimento de programas de pesquisa com objetivos tecnológicos específicos, marcos científicos a serem atingidos, e aplicação de uma estratégia técnica ao longo do tempo (DOE, 2006). Technology roadmaps foram utilizados para estudar o papel do biobutanol, entre outros produtos, como um biocombustível a ser obtido de biomassa lignocelulósica por via fermentativa ou termicamente a partir de gás de síntese (NSF, 2008) 
3.5 - Technology roadmaps para biocombustíveis no Brasil

O Brasil tem programas específicos para integrar a pesquisa em cana-deaçúcar e outras culturas que podem ser utilizadas para produção de etanol e outros biocombustíveis, assim como produtos de biorrefinarias integradas (FAPESP, 2012). Diferentes tipos de biomassa são estudados para a produção de energia, avaliando seu potencial em termos de viabilidade técnica, econômica, social e ambiental, assim como são sugeridas políticas para sua implementação (CENBIO, 2012).

O uso de biomassa já representa uma fatia de $4.7 \%$ da oferta nacional de energia, conforme representado na FIGURA 6. A biomassa neste contexto inclui lenha, bagaço de cana, licor negro da fabricação de celulose, e outras recuperações (BRASIL, 2011).

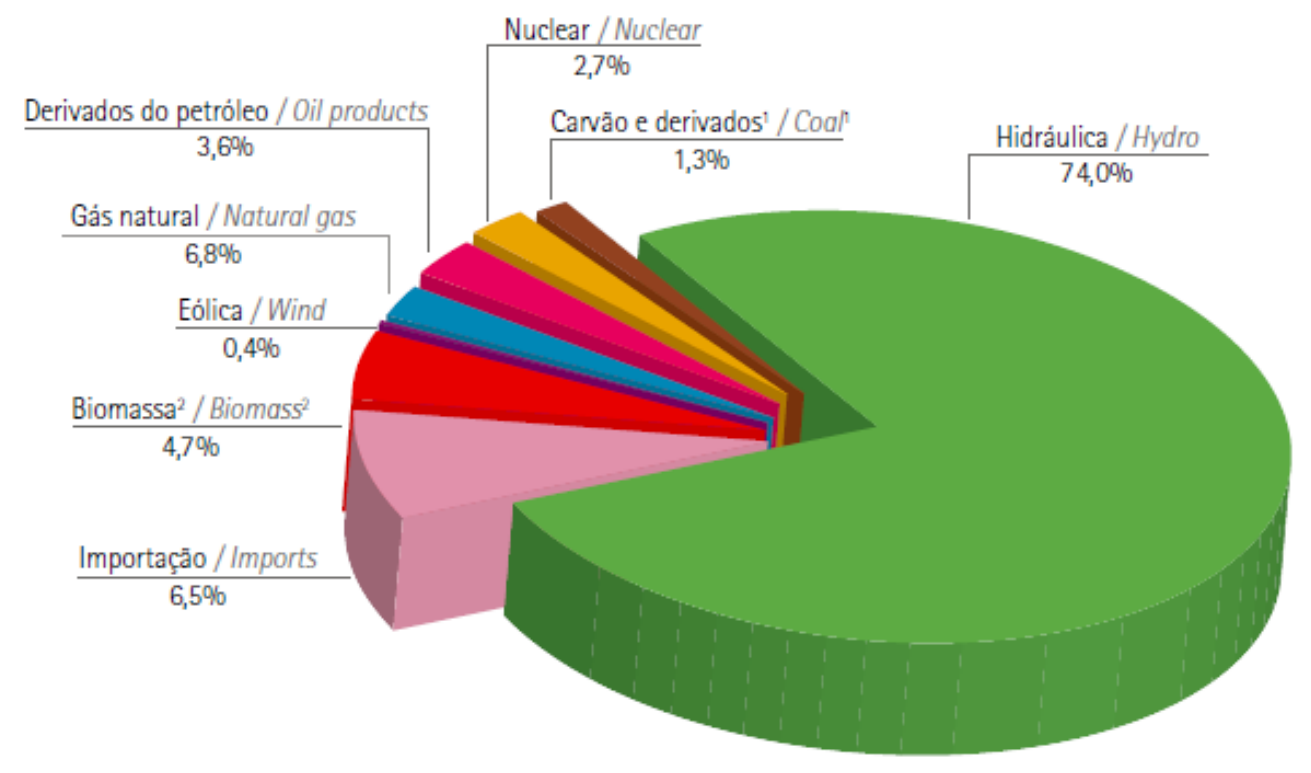

FIGURA 6: Oferta nacional de energia (fonte: BRASIL, 2011).

A cana-de-açúcar é responsável por uma parcela considerável da matriz energética brasileira. O bioetanol é utilizado como combustível no país desde 1975, e hoje é comercializado de forma pura ou misturado a uma taxa de até $25 \%$ à gasolina (GOLDEMBERG, 2011).

Estudos estratégicos foram conduzidos para garantir a sustentabilidade e liderança do país na produção de bioetanol em um cenário de crescente demanda global por energia limpa. O projeto visou identificar as condições para o país 
produzir de forma sustentável grandes quantidades de etanol combustível. (CGEE, 2009). O Ministério da Ciência, Tecnologia e Inovação coordena as atividades estruturantes para inovação no setor de energia limpa e renovável, biotecnologia, biodiversidade e mudanças climáticas. (MCTI, 2012).

No Brasil, o interesse pelo uso dos technology roadmaps é crescente. No ano de 2009, foram realizados seminários para divulgação da metodologia, com a presença de notáveis especialistas internacionais, como, por exemplo:

- Seminário Technology Roadmapping: Conceitos, Práticas e Perspectivas, Escola Politécnica da USP, São Paulo/SP, 31 de agosto de 2009. (OLIVEIRA e ROZENFELD, 2009).

- Workshop sobre Roadmaps Tecnológicos, UNICAMP, Campinas/SP, 11 de setembro de 2009. (CORTEZ, 2009).

O Centro de Gestão e Estudos Estratégicos - CGEE tem utilizado o formato dos roadmaps para divulgar políticas tecnológicas em diversas áreas. Um roadmap recente (CGEE, 2012) traz um exemplo do uso da metodologia para ao propor rotas tecnológicas para o uso limpo e eficiente do carvão mineral nacional. O mesmo formato foi utilizado para o desenvolvimento de biocombustíveis aeronáuticos (CGEE, 2010b). O NIPE - Núcleo Interdisciplinar de Planejamento Energético coordenou um completo roadmap lançado em junho de 2013 para o desenvolvimento sustentável de biocombustíveis aeronáuticos no Brasil - SABB Sustainable Aviation Biofuels for Brazil (NIPE, 2012).

CORTEZ (2010) coordenou uma equipe de especialistas para estudar o bioetanol de cana-de-açúcar. Foram reunidos mais de 500 pesquisadores, e realizados 18 workshops tecnológicos para o diagnóstico e elaboração de prospecção e desenvolvimento de cenários visando à elaboração de propostas de pesquisa, desenvolvimento e inovação e de propostas de diretrizes, estratégias e políticas públicas para o setor sucroalcooleiro. O roadmapping apresentado foi formado pelos seguintes componentes:

- Melhoramento genético e biotecnologia;

- Manejo agrícola;

- Hidrólise da celulose; 
- Termoconversão de biomassa.

SANTOS (2011) utilizou o technology roadmapping para estudo de produtos de lignina no Brasil, dentro de um conceito de biorrefinarias, como um subproduto de alto volume na indústria de papel e celulose, e potencial subproduto no desenvolvimento de biocombustíveis por hidrólise da celulose.

Também utilizando o mapeamento tecnológico, o CGEE elaborou um documento sobre o desenvolvimento da "química verde", para estruturação de uma política nacional, marcos regulatórios, e fortalecimento das estruturas do agronegócio, a fim de criar uma economia voltada para bioprodutos. Em parte deste estudo, foram revisitadas as rotas já utilizadas no passado no Brasil para produção de butanol. A FIGURA 7 mostra as possibilidades de produtos que podem ser obtidos através da fermentação da glicose, ou da futura hidrólise da celulose a glicose. Foram também verificadas como possíveis novas rotas que incluem a conversão de bioetanol em biobutanol. O estudo indica que esta rota encontra-se ainda na fase de pesquisa no período 2010-2015, com sucessivos estágios até sua possível comercialização no período 2026-2030 (CGEE, 2010a).

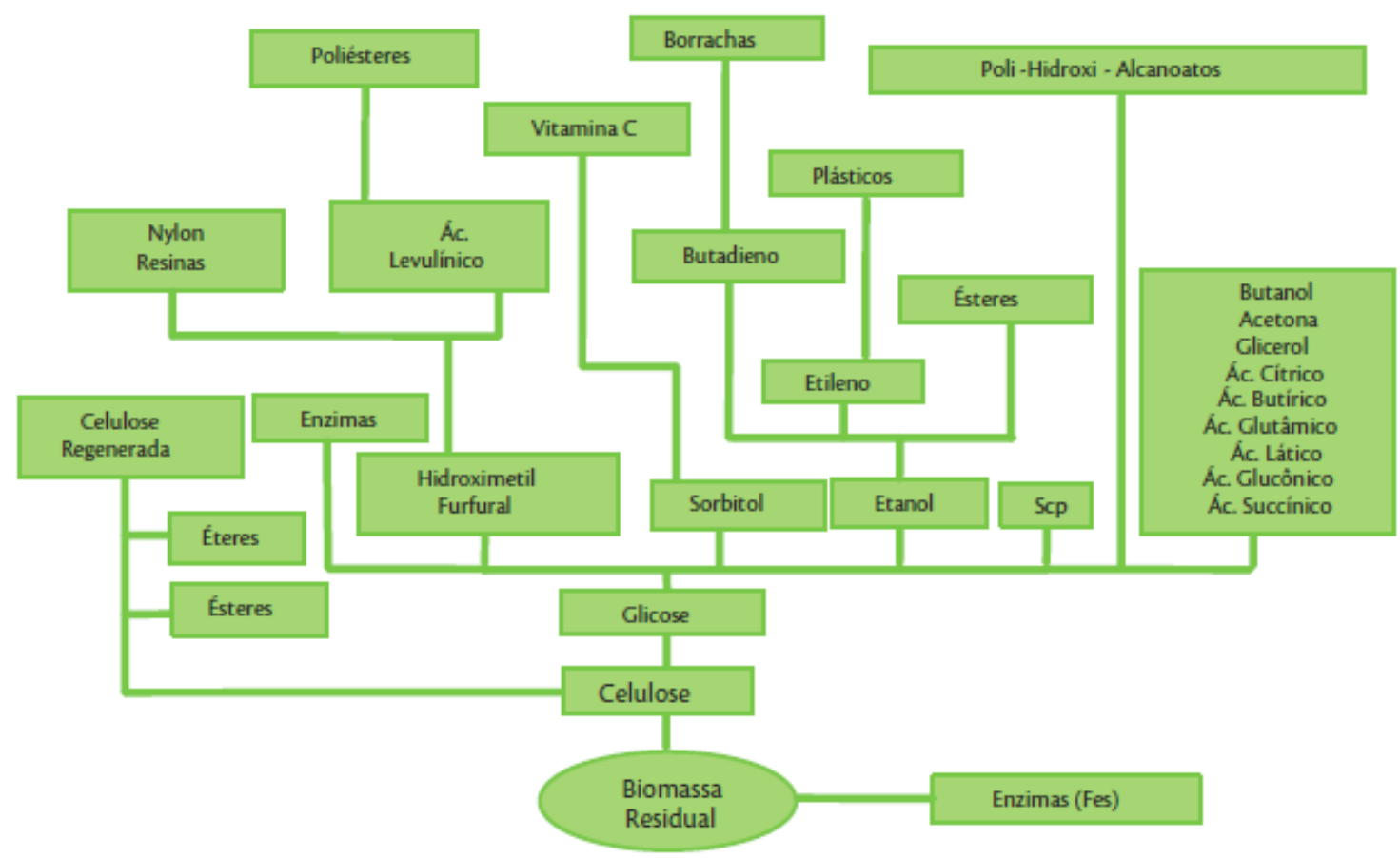

FIGURA 7: Possíveis produtos de biorrefinaria lignocelulósica (PEREIRA JR. et al., 2008, apud CGEE 2010 a). 
A empresa Braskem aplicou os technology roadmaps para definir suas prioridades em produtos de fontes renováveis, denominados de química verde. Durante esta revisão, um dos produtos estudados foi o biobutanol. Este estudo indicou que, devido a suas promissoras características como combustível e intermediário químico, o biobutanol a partir de rotas fermentativas tem sido intensamente pesquisado por diversas empresas. A sua comercialização é esperada a curto prazo, em até 5 anos, conforme a FIGURA 8 (COUTINHO e BOMTEMPO, 2010). As empresas destacadas neste estudo foram Cathay, Cobalt, Dupont e Gevo.

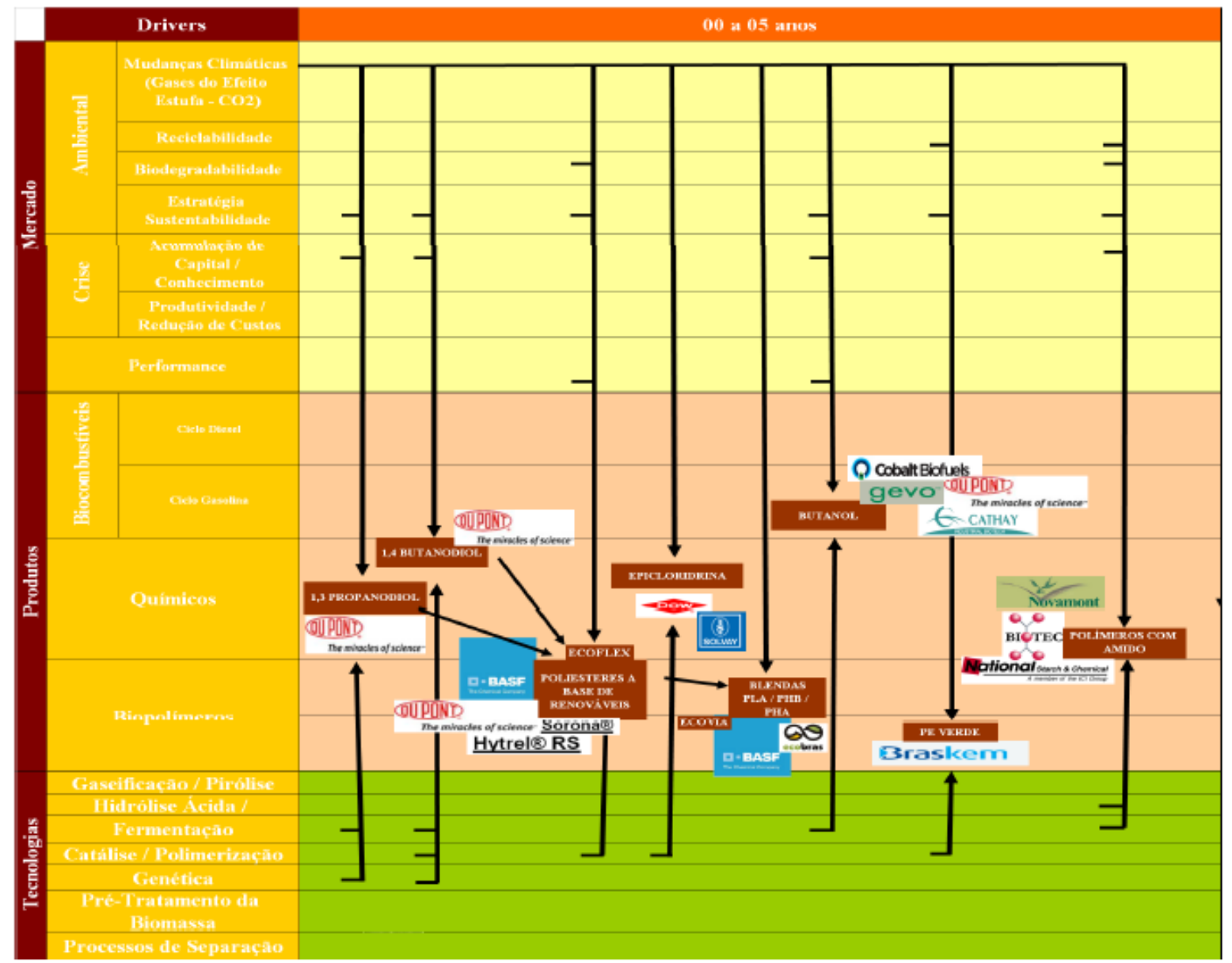

FIGURA 8: Roadmap da Braskem para matérias primas renováveis a curto prazo (COUTINHO e BOMTEMPO, 2010). 


\section{Parte B: Butanol}

\section{6- Perspectiva histórica}

Em 1862, Louis Pasteur foi o primeiro a registrar a fermentação de glicose a butanol (HARVEY e MEYLEMANS, 2011). A produção industrial de biobutanol iniciou-se ao redor do ano de 1912, com as pesquisas do Dr. Chaim Weizmann (BOHLMANN, 2007). O processo fermentativo, conhecido como ABE (acetonabutanol-etanol), foi empregado para fermentar carboidratos utilizando a bactéria Clostridium acetobutylicum resultando principalmente em acetona e n-butanol. Este processo atingiu o patamar de processo industrial fermentativo de larga escala, sendo o segundo mais representativo em volume, atrás apenas do processo fermentativo do etanol. Havia diversas plantas produtivas em operação nos Estados Unidos, Canadá, África do Sul, na antiga União Soviética e em alguns países asiáticos. (BOHLMANN, 2007).

Após o seu auge em torno de 1950, contudo, os problemas persistentes com a confiabilidade do processo fermentativo e o aumento consecutivo dos preços de melaços, causaram um declínio na produção de biobutanol (BOHLMANN, 2007). Processos sintéticos foram introduzidos com a crescente indústria petroquímica na época, que oferecia rotas a custos mais efetivos para obtenção de petro-butanol.

Atualmente o butanol é produzido principalmente através de processo sintético conhecido como hidroformilação, ou processo oxo. Ele envolve a reação de uma oleofina, por exemplo, propileno, com monóxido de carbono e hidrogênio para produzir um aldeído. Este processo foi adaptado largamente para a produção de isobutiraldeído e n-butiraldeído, que são convertidos em seguida a isobutanol e n-butanol. (NEXANT, 2007).

Desde a década de 1990, com o contínuo aumento do custo do petróleo, pesquisadores voltaram-se novamente à investigação de possíveis melhorias na rota fermentativa $A B E$, através do emprego das técnicas de engenharia genética, reatores fermentativos mais produtivos, e novas tecnologias de recuperação do solvente do meio fermentativo. Novas cepas de bactérias conhecidas como Clostridium beijerinckii BA 101, demonstraram eficiência na conversão de amido 
em acetona e butanol (BOHLMANN, 2007). A empresa Tetravitae usou este processo com sistema de remoção de gases de processo para remoção de solventes in situ. A empresa Gevo desenvolveu microorganismos mais resistentes aos solventes, e a DuPont contribuiu com novos sistemas de recuperação de solvente (BOHLMANN e BRAY, 2008).

A fermentação $A B E$ tradicional atingiu produção muito significativa na China com 30 fábricas e 170.000 toneladas de produção anual. Durante os anos 1990, contudo, foi levada ao declínio devido à concorrência com a rota petroquímica. O país iniciou uma nova rodada de pesquisa sobre fermentação em processos contínuos para aumentar a produtividade e permitir maior competitividade da rota fermentativa (CHIAO e SUN, 2007).

No Brasil, durante a fase do Proálcool, muitos derivados de etanol foram produzidos pela rota alcoolquímica (VILLELA FILHO, 2011). Nesta época, o butanol foi produzido a partir da conversão de etanol a butanol. Este processo envolvia a desidrogenação do etanol, gerando hidrogênio e acetaldeído. Na etapa final o hidrogênio era utilizado na hidrogenação do crotonaldeído, gerando butanol (CGEE 2010a; RODRIGUES, 2011). A partir de 2008 a empresa HC Sucroquímica passou a fabricar novamente butanol no Rio de Janeiro.

\section{7 - Produtos, produção e usos}

Butanol é um álcool de quarto carbonos com quatro isômeros estruturais: n-butanol, isobutanol, terc-butanol e sec-butanol, conforme a FIGURA 9.

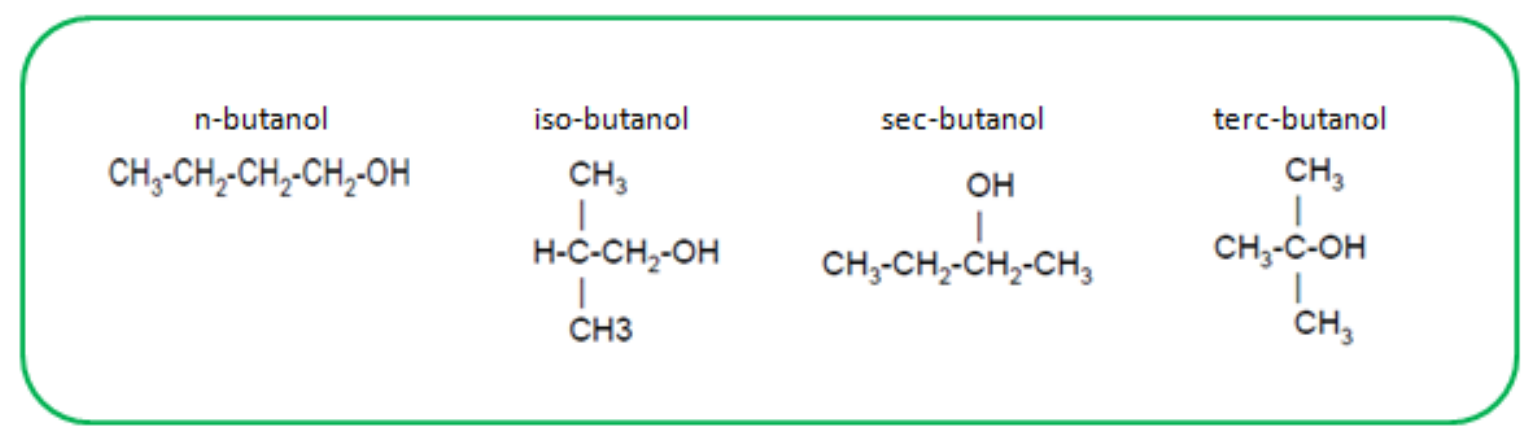

FIGURA 9: Isômeros do butanol (elaboração própria). 
A demanda mundial para n-butanol foi de 3.800.000 toneladas em 2010. A demanda global por isobutanol foi de 400.000 toneladas. O n-butanol é utilizado como solvente para tintas e vernizes, ou como matéria prima para a produção de outros materiais, como acrilato de n-butila, um monômero chave para a produção de polímeros e emulsões utilizados em tintas para construção civil. Outros usos incluem acetato de n-butila como solvente, assim como éteres de glicol, plastificantes, extração de ativos farmacêuticos e cosméticos. $O$ isobutanol pode ser utilizado como solvente, na preparação de plastificantes, agentes de flotação ou na produção de acetato de isobutila para uso como agente flavorizante (MASCAL, 2012). Os outros álcoois, terc-butanol e sec-butanol, têm menor consumo e são utilizados principalmente como solventes, denaturantes para etanol, e removedores de tintas.

O butanol é produzido atualmente em sua maior parte pela rota petroquímica utilizando o processo oxo. Os maiores produtores globais são Dow, Basf, Celanese, e Eastman, além da Sasol na África do Sul, KH Neochem no Japão e Elekeiroz no Brasil (NEJAME, 2010). Parte do n-butanol consumido na China é produzido por via fermentativa pela Cathay desde 2008 (CATHAY, 2012). A produção mundial de biobutanol em 2008 foi de cerca de 100.000 toneladas, principalmente na China e algumas usinas de demonstração nos Estados Unidos. No Brasil, a HC Sucroquímica, adjacente à Usina Paraíso, localizada em CamposRJ, tem capacidade estimada em 20.000 toneladas de biobutanol anuais, embora sua produção historicamente tenha sido menor que este volume.

A FIGURA 10 mostra a capacidade produtiva atual de n-butanol instalada no mundo. Existe capacidade de n-butanol por rotas fermentativas, contudo não existem anúncios oficiais significativos de novas fábricas até 2017. Os anúncios recentes limitam-se a plantas de demonstração de processo, em diferentes escalas.

Na FIGURA 11 estão listados os principais produtores mundiais de $\mathrm{n}$ butanol atualmente, classificados por sua capacidade produtiva. Estão agrupadas várias fábricas do mesmo produtor em diferentes localidades, portanto o número final retratado é a produção total do grupo. Em destaque estão as fábricas que têm processos fermentativos para biobutanol. 


\section{Capacidade Produtiva n-butanol - Global}

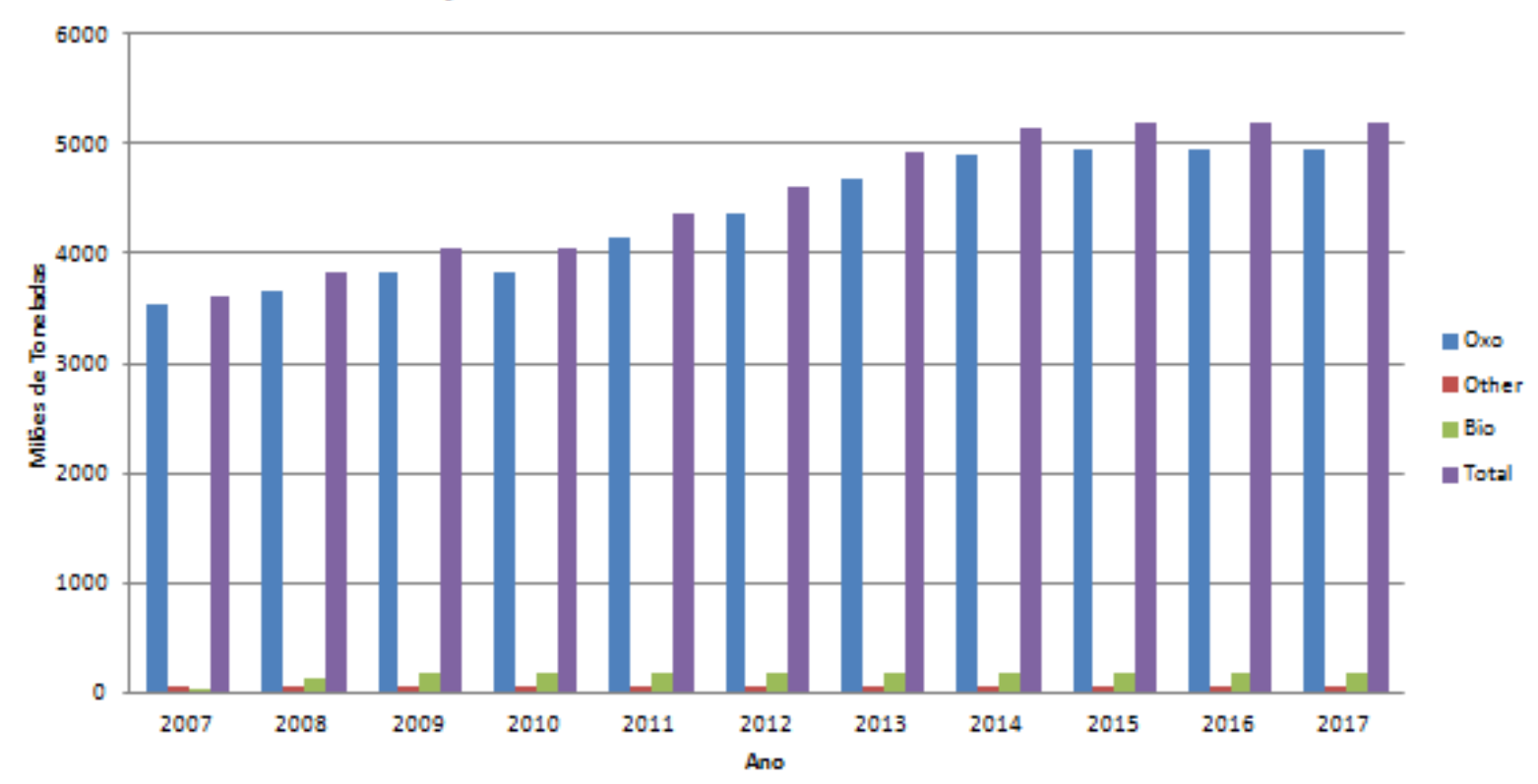

FIGURA 10: Capacidade produtiva de n-butanol instalada mundialmente (elaboração própria, com dados IHS - CMAI).

\begin{tabular}{|c|c|c|}
\hline EMPRESA & LOCALIDADE & 2012 (MT) \\
\hline BASF Corp. & $\begin{array}{l}\text { EUA, Alemanha, } \\
\text { China, Malásia }\end{array}$ & 975 \\
\hline Dow & EUA, Malásia & $\omega 81$ \\
\hline Oxea & EUA, Alemanha & 350 \\
\hline Eastman & EUA, Cingapura & 237 \\
\hline Jilin Chemical & China & 198 \\
\hline SASOL & EUA, A frica Sul & 173 \\
\hline BlueStar Tianjin & China & 150 \\
\hline Oxochimie & Franca & 140 \\
\hline Gazprom Neftekhim & Rússia & 139 \\
\hline Kyowa Hakko & Japăo & 130 \\
\hline Perstom & Suécia & 100 \\
\hline Baling PC & China & 100 \\
\hline Mitsub. Chemical & Japăo & 95 \\
\hline Lihuayi Group & China & 85 \\
\hline Tianjin Soda & China & 85 \\
\hline LG Chem & Coréia & 70 \\
\hline Sibur Khimpron & Rússia & 68 \\
\hline Anoarsk Petchem & Rússia & 62 \\
\hline Jinmaoyuan BioChem & China & 60 \\
\hline Songyuan Jian BC & China & 60 \\
\hline PetroChina Daqing $\mathrm{PC}$ & China & 50 \\
\hline Qilu PC & China & 50 \\
\hline Elekeiroz SA. & Brasil & 40 \\
\hline Lianhail Biotech & China & 35 \\
\hline Euruchell & Fissia & 92 \\
\hline Jilin Cathay Biotech & China & 30 \\
\hline Cilsoufe & Japằ & 20 \\
\hline Andhra PC & India & 23 \\
\hline ZA. Kedzierzyn & Polönia & 20 \\
\hline Beijing Dongfang & China & 20 \\
\hline Petro-Oxo Nusantara & Indonésia & 20 \\
\hline Shanghai PC & China & 15 \\
\hline Hanwha Chemical & Coréia & 10 \\
\hline Oltchim & Romênia & 7 \\
\hline Shaanxi & China & 7 \\
\hline Kolhapur Sugar & India & 6 \\
\hline Arak PC & Iră & 5 \\
\hline J. R. Oganics Ltd. & Vietna & 3 \\
\hline
\end{tabular}

FIGURA 11: Produção por fabricante (elaboração própria com dados IHS-CMAI) 
3.8 - Tecnologias para produção de biobutanol por rota biológica

O uso sustentável de biomassa sugere sua transformação em produtos tais como biocombustíveis, químicos, polímeros, farmacêuticos, polpa e papel, alimentos, ração animal (CHERUBINI, 2011) e energia. Uma biorrefinaria é uma unidade, ou conjunto de unidades, que integra processos de conversão de biomassa em biocombustíveis, energia e químicos "verdes" (MELLO JUNIOR, 2010). Esta unidade de produção atuaria de maneira análoga uma refinaria atual baseada em matérias primas fósseis (CHERUBINI, 2011).

SEABRA (2008) descreve algumas das rotas possíveis para aproveitamento de biomassa, reproduzidas na FIGURA 12. Seria possível o estudo de rotas termoquímicas para produção de bio-óleo ou gaseificação, ou o uso de rotas bioquímicas para a fermentação ou produção de bio-gás. A rota oleoquímica é utilizada para produção de biodiesel.

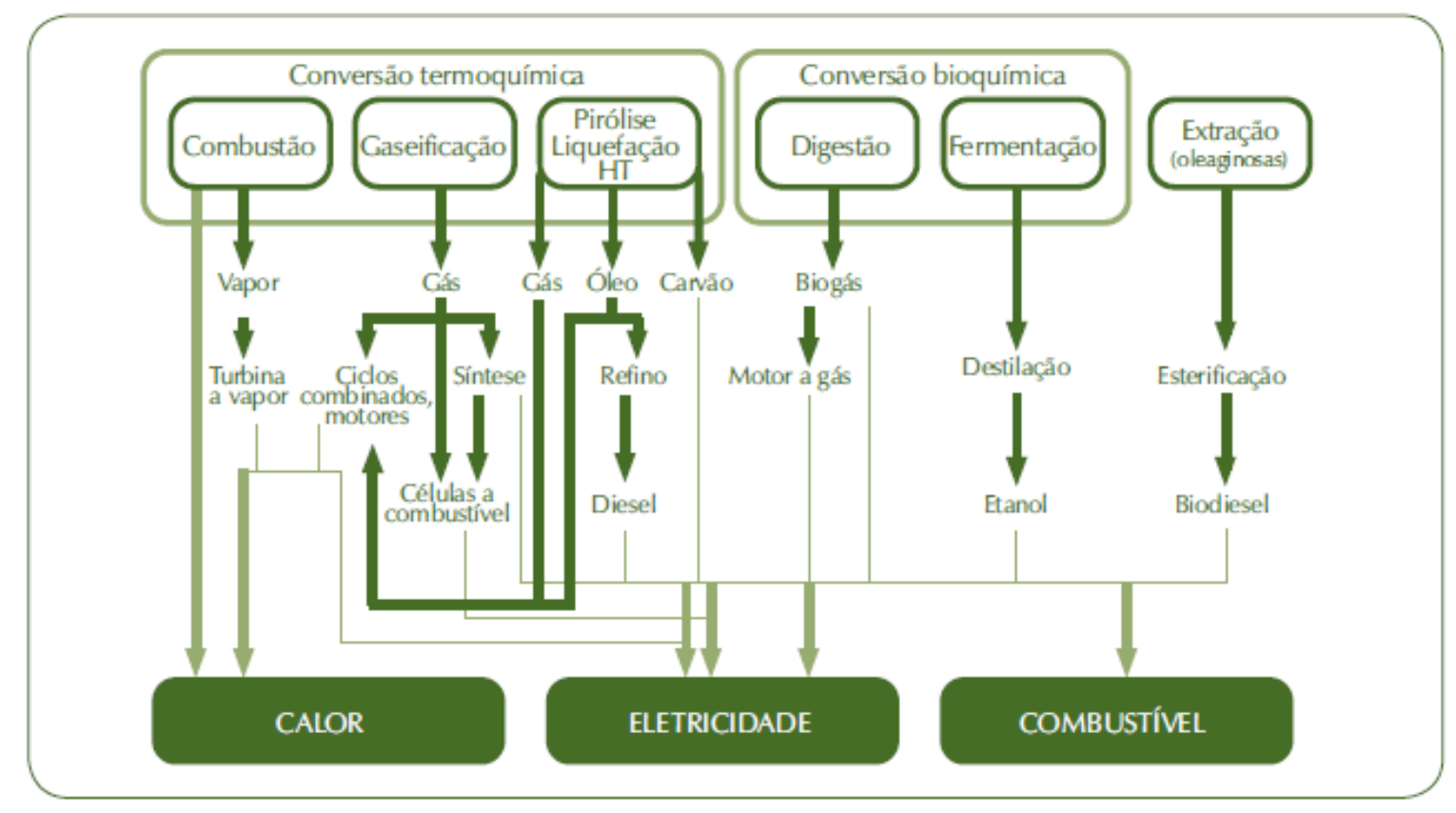

FIGURA 12: Rotas tecnológicas para produção de bioenergia (SEABRA, 2008).

Existem diversas tecnologias propostas para a produção de biobutanol. $\mathrm{O}$ produto pode ser preparado por diferentes processos fermentativos, ou por processos termoquímicos. Alguns dos processos propostos estão em estágio inicial de desenvolvimento e ainda não estão disponíveis comercialmente. 
(RODRIGUES, 2011). Também são conhecidas as rotas alcooquímicas, na qual o etanol é convertido a butanol (VILLELA FILHO, 2011).

CASCONE (2009) resumiu os principais processos existentes ou em desenvolvimento para a obtenção do biobutanol, reproduzidos na FIGURA 13. Os processos existentes envolvem a tradicional fermentação ABE. Esta é realizada a partir de açúcares provenientes de fontes como cana-de-açúcar e beterraba, ou ainda de amido, cuja principal fonte é o milho, seguida pela mandioca. Neste caso o amido é tratado com enzimas para liberação dos açúcares e posterior fermentação. O processamento de outros tipos de grãos pode ser realizado após etapas prévias de tratamento, que envolvem moagem, cozimento, hidrólise e sacarificação (IEA, 2011).

Processos similares de fermentação podem ser utilizados para obtenção de etanol e, neste caso, seria posteriormente convertido cataliticamente a butanol. É usada a reação de Guerbet, onde um álcool alifático primário é convertido em um dímero com perda de uma molécula de água. O processo é realizado na presença de catalisadores e temperaturas elevadas. (NEXANT, 2008)

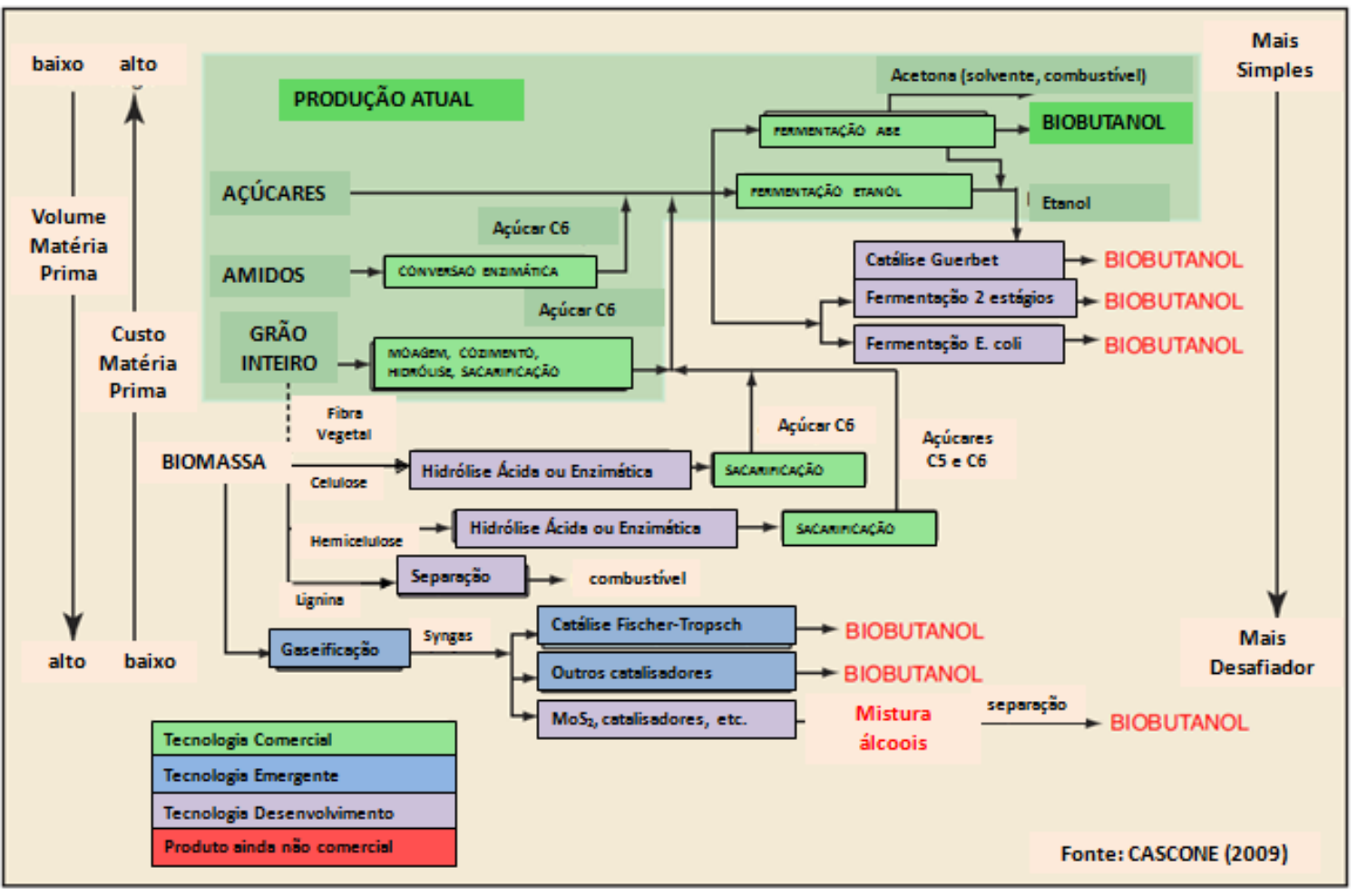

FIGURA 13: Processos para obtenção de biobutanol (adaptado de CASCONE, 2009). 
Após a extração dos açúcares, os resíduos do processamento são compostos por palha e bagaço de cana, folhas e sabugo de milho. Outras biomassas abundantes incluem resíduos florestais, madeira e papel. Processos em evidência atualmente envolvem a conversão desta biomassa residual através do pré-tratamento para liberação de seus componentes principais, ou seja, celulose, hemicelulose e lignina (MELZOCH, 2010). A FIGURA 14 ilustra este processo de liberação dos componentes da biomassa.

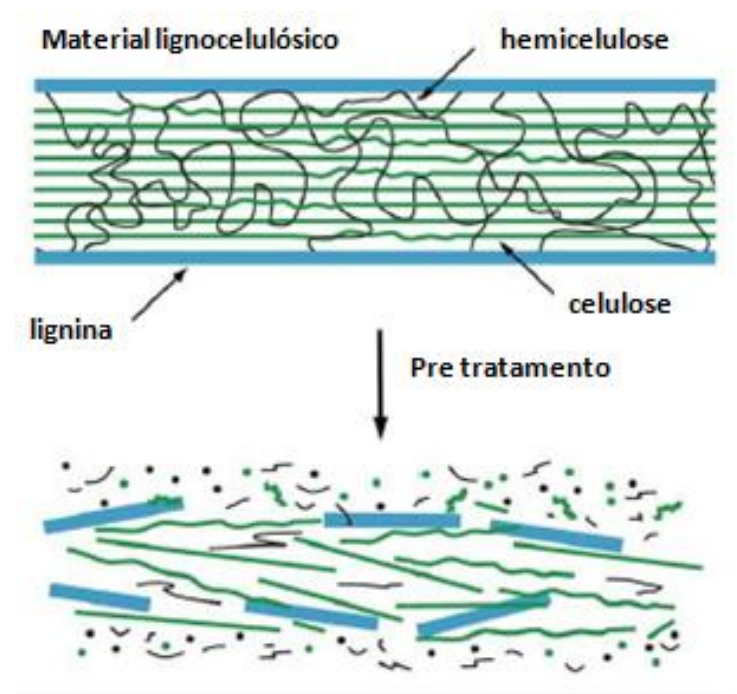

FIGURA 14: Pré-tratamento da biomassa (MELZOCH, 2010).

A hidrólise tem sido pesquisada para conversão de celulose $\mathrm{e}$ hemicelulose em seus respectivos açúcares (SANTOS, 2011). A TABELA 1 mostra que a biomassa é composta em linhas gerais por $40 \%$ de celulose, $25 \%$ de hemiceluloses, e $20 \%$ de lignina. Estes percentuais variam dependendo da espécie vegetal em consideração. Também podem ser trabalhados por engenharia genética para privilegiar um dos componentes que seja mais vantajoso a determinado processo. O percentual restante é composto por outros materiais e cinzas. Uma vez decomposta a estrutura principal da biomassa lignocelulósica, a celulose pode ser convertida a hexoses e a hemicelulose a pentoses. Os açúcares de seis carbonos, denominados hexoses, e os açúcares de cinco carbonos, denominados pentoses, podem então ser convertidos a biobutanol através dos processos tradicionais $A B E$ ou de novos processos melhorados para aumento de seletividade e produtividade de butanol na fermentação (IEA, 2012; BOHLMANN, 2008). 
TABELA 1: Composição dos materiais lignocelulósicos (SANTOS, 2011).

\begin{tabular}{|c|c|c|c|}
\hline Componentes & Características & Composição & Processamento \\
\hline Celulose & $\begin{array}{c}\text { polímeros de glicose com alto } \\
\text { peso molecular que sāo mantidos } \\
\text { rigidamente juntos como feixes } \\
\text { de fibras para fornecer força ao } \\
\text { material. Presente em regiōes } \\
\text { cristalina e amorfa. Insolúvel em } \\
\text { álcalis. } \\
\end{array}$ & $\begin{array}{l}\text { Cerca de } 40 \% \\
\text { em peso da } \\
\text { biomassa. }\end{array}$ & \multirow{2}{*}{$\begin{array}{l}\text { Podem ser quebrados } \\
\text { em açúcares e } \\
\text { eventualmente } \\
\text { fermentados para } \\
\text { produçāo de etanol. }\end{array}$} \\
\hline Hemicelulose & $\begin{array}{c}\text { polímeros pequenos de vários } \\
\text { açúcares de celulose. Presente } \\
\text { somente em regiōes amorfas. } \\
\text { Solúvel em álcalis. } \\
\end{array}$ & $\begin{array}{l}\text { Cerca de } 25 \% \\
\text { em peso da } \\
\text { biomassa. }\end{array}$ & \\
\hline Lignina & $\begin{array}{l}\text { polímero tridimensional de } \\
\text { fenilpropânico que é infiltrado no } \\
\text { componente hemicelulose. }\end{array}$ & $\begin{array}{l}\text { Cerca de } 20 \% \\
\text { em peso da } \\
\text { biomassa. }\end{array}$ & $\begin{array}{l}\text { Pode ser quimicamente } \\
\text { processada para } \\
\text { produzir aditivos de } \\
\text { combustíveis, ou } \\
\text { degradada por } \\
\text { microorganismos, } \\
\text { produzindo fenóis, } \\
\text { vanilina e outros } \\
\text { componentes. }\end{array}$ \\
\hline
\end{tabular}

A busca por melhoria de produtividade no processo ABE é intensa. Uma das primeiras patentes neste sentido utilizou o conceito de processo em duas etapas, denominado Dual Immobilized Reactors with Continuous Recovery (DIRCR). Neste processo são utilizadas duas bactérias, Clostridium tyrobutylicum (CT) e Clostridium acetobulylicum (CA). O CT maximiza a produção de hidrogênio e ácido butírico, enquanto o CA converte o ácido butírico a butanol. (CHEN, 2009).

As propostas para rotas termoquímicas de conversão incluem a pirólise rápida, carbonização (também conhecida como pirólise lenta) e gaseificação, conforme demonstrado no QUADRO 2 (ROCHA, 2004). O líquido pirolítico obtido é uma mistura complexa de compostos orgânicos o qual, embora tenha natureza química diferente do petróleo, pode ser considerado como um petróleo de origem vegetal. É muitas vezes conhecido como bio-óleo. Este processo também é conhecido como transformação de biomassa a líquidos, ou, por seu termo original em Inglês: BTL - Biomass to liquid. Existem também propostas de unidades satélites para pirólise e obtenção de bio-óleo, próximas aos centros produtores, para facilitar seu posterior transporte. A biomassa liquefeita apresenta densidade de $1200 \mathrm{~kg} / \mathrm{m}^{3}$, muito superior à densidade da biomassa sólida que situa-se entre 80 a $240 \mathrm{~kg} / \mathrm{m}^{3}$. Uma vez obtido, pode ser enviado a unidades de refino para obtenção de combustíveis. (CORTEZ, 2009). 


\begin{tabular}{|c|c|c|c|c|}
\hline & & Líquido & Carvão & Gás \\
\hline Pirólise rápida & $\begin{array}{l}\text { Temperatura de processo moderada }(450- \\
\left.550^{\circ} \mathrm{C}\right) \text {, curtos tempos de residência dos } \\
\text { vapores e biomassa }\left(\begin{array}{lll}< & \text { s }) \text { com baixa } \\
\text { granulometria. }\end{array}\right.\end{array}$ & $75 \%$ & $12 \%$ & $13 \%$ \\
\hline Carbonização & $\begin{array}{l}\text { Baixas temperaturas }\left(400-450^{\circ} \mathrm{C}\right) \text {, curtos } \\
\text { tempos de residência (pode ser de horas ou } \\
\text { dias), particulas grandes. }\end{array}$ & $30 \%$ & $35 \%$ & $35 \%$ \\
\hline Gaseificação & $\begin{array}{l}\text { Alta temperatura }\left(900^{\circ} \mathrm{C}\right) \text {, longos tempos de } \\
\text { residência. }\end{array}$ & & $10 \%$ & $85 \%$ \\
\hline
\end{tabular}

QUADRO 2: rendimentos dos produtos típicos por diferentes técnicas de pirólise (ROCHA et al., 2004).

O bio-óleo pode também ser enviado para uma unidade central de gaseificação. A conversão da biomassa em gás combustível permite a utilização em motores e turbinas em aplicações de geração de energia elétrica. (CORTEZ, 2009). A biomassa gaseificada, também conhecida como gás de síntese, é rica em hidrogênio e gás carbônico. Através de sua conversão catalítica é possível obter diversos tipos de combustíveis, com características similares à gasolina e ao diesel (MUNASHINGHE, 2011), ou ainda novos biocombustíveis com destaque para DME - dimetiléter, e butanol (PHILLIPS, 2007; ELY, 2009; VALENÇA, 2012).

Em resumo, os principais processos potenciais para a produção de biobutanol são (JANSSENS, 2011):

- Fermentação: conversão de carboidratos seja diretamente por fermentação dos açúcares ou após hidrólise. Os processos atuais são baseados na fermentação ABE (acetona-butanol-etanol), e intenso desenvolvimento existe para aperfeiçoamento dos processos em termos de melhor produtividade, seletividade, e economia de escala.

- Alcoolquímico: obtenção de etanol através da fermentação tradicional por leveduras, e posterior condensação do etanol a butanol por síntese de Guerbet.

- Termo-químico: pirólise e gaseificação da biomassa para obtenção de diversos produtos, incluindo butanol. 
As possíveis matérias primas vegetais para produção de biocombustíveis, incluindo o butanol, podem ser provenientes de diversas fontes (MELZOCH, 2010). Estas incluem:

- Fontes tradicionais de açúcares: milho, cana-de-açúcar, beterraba.

- Matérias primas de segunda geração: hidrolisados de material lignocelulósico e resíduos da extração de açúcares.

- Fontes alternativas de carbono: algas (DOE, 2010), trigo, glicerina da produção de biodiesel, madeira e resíduos florestais (VAN BUEREN e VICENT, 2003).

As rotas mais prováveis para desenvolvimento de biobutanol em curto prazo são as rotas bioquímicas para fermentação (CASCONE, 2009). Ao selecionar uma tecnologia bioquímica potencial para produzir biobutanol, alguns dos aspectos mais importantes a considerar incluem:

- o tipo, custo e disponibilidade de biomassa;

- os microorganismos sendo utilizados;

- a técnica fermentativa e o tipo de reator;

- a técnica de recuperação utilizada para isolar e purificar o solvente.

O processo mais difundido para produzir biobutanol ainda é a tradicional fermentação ABE (Acetona-Butanol-Etanol). Suas principais limitações segundo KUMAR (2012), são:

- baixa viabilidade econômica devido à dificuldade de obtenção de grandes quantidades de matéria prima a custo competitivo;

- baixos rendimentos, pois o butanol é tóxico aos microorganismos em concentrações muito baixas;

- processos de recuperação de produto ineficientes e de alto custo.

O milho tem sido a matéria prima tradicional nos Estados Unidos. A fermentação $A B E$ emprega uma variedade de bactérias do gênero Clostridia para produzir acetona, butanol e etanol ( $A B E)$, usualmente na proporção de 3:6:1 partes. Os processos fermentativos existentes empregam matérias primas que permitem que açúcares contendo seis carbonos sejam fermentados a butanol. Amido e grãos podem ser processados e convertidos a açúcares para posterior fermentação. $O$ uso de milho para geração de etanol gera diversos questionamentos em função da concorrência com a cadeia alimentar, e ainda do 
ponto de vista ambiental, indagando se este processo é sustentável. Um estudo de ciclo de vida (ACV, ou LCA por suas siglas em Inglês) indicou que o butanol, por seu maior conteúdo energético, poderia ser um produto mais sustentável que o etanol quando produzido a partir de milho. A energia líquida gerada pelo biobutanol via fermentação $A B E$ de milho era $6.53 \mathrm{MJ} / \mathrm{L}$, comparado com apenas $0.40 \mathrm{MJ} / \mathrm{L}$ produzidos da correspondente manufatura de bioetanol de milho (SWANA, 2011). Contudo, ao se considerar os subprodutos, como acetona, a análise de ciclo de vida completa da cadeia do butanol de milho por processos ABE tradicionais indicou não ser tão efetiva, comparada com o etanol de milho, principalmente no tocante a emissões de gases de efeito estufa ou GHG Greenhouse gases (ARGONNE, 2010). Isto indica a necessidade de aperfeiçoamento do processo ABE (JANG, 2012).

A produção de bioetanol de cana-de-açúcar, conforme praticada no Brasil, associada com produção de energia e açúcar, apresenta um retorno atrativo quanto ao uso de mão de obra e recursos naturais para produção de biocombustíveis. Atualmente o bioetanol de cana é economicamente competitivo, não afeta a cadeia alimentar humana, tem excelente produtividade em termos de uso de biomassa, apresenta uma excelente relação entre os combustíveis fósseis utilizados para sua produção e a bioenergia gerada (aproximadamente 10 vezes), e contribui para a redução de gases de efeito estufa (GCEE, 2012b).

Recentemente, a cana-de-açúcar tem sido também estudada como uma matéria prima adequada para a produção economicamente viável de butanol quando comparada com outras matérias primas. Ela é uma fonte abundante de carbohidratos solúveis, que são prontamente processáveis via fermentação (VILLELA FILHO, 2011). Os aspectos econômicos e de engenharia de um processo $A B E$ a partir de cana-de-açúcar no Brasil foram modelados por MANSUR (2010), indicando a possibilidade de operação de uma unidade lucrativa. Processos para produção de biobutanol a partir de melaço também foram estudados (VAN DER MERWE, 2010; NI, 2012).

O principal avanço na utilização de matérias primas deverá ocorrer com o desenvolvimento de processos de hidrólise para quebrar a celulose e hemiceluloses em açúcares fermentáveis. Processos de hidrólise ácida e 
enzimática têm sido intensamente pesquisados para permitir o uso de grandes quantidades de material lignocelulósico que não gerem concorrência ao oferecimento de alimentos. Estes materiais incluem resíduos da agricultura, como sabugo de milho, capim elefante, palha de trigo, e bagaço de cana (KUMAR, 2012).

Apesar de suas estruturas químicas similares, a celulose diferencia-se do amido porque as cadeias de polissacarídeos são lineares e estão fortemente ligadas entre si por meio de pontes de hidrogênio. Além disso, interagem com as hemiceluloses e lignina nas paredes celulares das plantas. Portanto, o prétratamento do material lignocelulósico é requerido para separar hemiceluloses, lignina, e outros componentes do substrato celulósico (FOYLE, 2007). A celulose deve ser hidrolisada para hexoses, isto é, açúcares com seis carbonos, permitindo a fermentação de glicose a butanol. A hemicelulose é composta de pentoses, ou seja, açúcares de cinco carbonos, o que requer microorganismos específicos para convertê-la em biocombustíveis..

Uma vez que esta barreira esteja superada, será possível o uso de inúmeros outros tipos de matérias primas, por exemplo, resíduos florestais. Espécies de crescimento rápido, assim como o álamo nos Estados Unidos e o eucalipto no Brasil, poderão também tornar-se importantes fontes de matéria prima para biorrefinarias integradas a fábricas de celulose e papel, onde poderá haver a produção de biocombustíveis incluindo o biobutanol (FOELKEL, 2012).

O processo produtivo para obtenção do biobutanol pode ser dividido em duas partes: a fermentação em si, e a separação do solvente do meio fermentativo. O grande desafio é encontrar microorganismos que tenham alta produtividade e seletividade na produção de butanol. Contudo, o próprio butanol gerado no processo é tóxico para grande parte dos microorganismos utilizados até hoje. Portanto, é necessário o desenvolvimento de microorganismos mais resistentes, juntamente com técnicas de retirada contínua de solvente do meio para que sua concentração seja mantida sempre a baixos níveis. (GREEN, 2011). O baixo rendimento faz que seja necessária uma grande quantidade de energia para remover a água e quebrar os azeótropos das misturas para purificar o butanol, etanol e acetona gerados. 
Consideramos, portanto, como os principais elementos no desenvolvimento da tecnologia de fermentação e separação (DURRE, 2011):

- Toxicidade do butanol aos microorganismos, tão baixa quanto $1 \%$ a $2 \%$ de concentração, que impede o crescimento microbiano e a geração de novo produto.

- Baixo rendimento com os microorganismos convencionais, em geral em torno de $12 \mathrm{~g} / \mathrm{L}$.

- Baixa seletividade do processo, gerando diversos outros solventes juntamente com o butanol.

- Elevada quantidade de água traduzindo-se em elevados custos de separação, e aumento do tamanho das plantas produtivas.

- Uso de substratos que concorrem com a cadeia alimentar, gerando debates sobre o tema "food for fuel".

- Degeneração da cultura de microorganismos, e elevado risco de contaminação com microorganismos externos ao processo.

\subsubsection{Microorganismos}

A grande maioria das bactérias utilizadas para a produção de biobutanol é do gênero Clostridium. Os primeiros microorganismos utilizados em fermentação industrial do biobutanol foram Clostridium acetobutylicum e utilizados durante várias décadas. Contudo, durante os anos 90 foi descoberto que algumas outras espécies de bactéria também eram efetivas na conversão, e iniciou-se o estudo e aprimoramento genético de C.beijerinckii, $C$. saccharoperbutylacetonicum e $C$. saccharobutylicum, entre outros. Bactérias Clostridia secretam uma grande variedade de enzimas que facilitam a quebra de carboidratos a monossacarídeos. Estes são transportados para dentro das células em processos regulados por membranas, onde são metabolizados com geração de diversos subprodutos, incluindo o butanol (EZEJI, 2007). Estudos apontam para aumento de produtividade para até 18-33g/L (JIN, 2011), utilizando engenharia genética (JANG, 2013). Durante o processo fermentativo, existem duas fases principais (a) acidogenêse, na qual ácidos são produzidos, e (b) solventogênese, na qual os ácidos são assimilados e os solventes são obtidos. Nas duas fases, a presença de butanol causa desestabilização da membrana celular dos microorganismos. 
Para os microorganismos convencionais, a concentração máxima de butanol tolerada é de $20 \mathrm{~g} / \mathrm{L}$. Portanto um dos focos no desenvolvimento está nas novas variedades de Clostridia com maior tolerância e resistência ao solvente. Outra alternativa é a remoção contínua de solvente, de maneira a deixar sua concentração sempre baixa no meio reacional.

Técnicas de engenharia genética têm sido empregadas para estudar e alterar microorganismos em aspectos chaves de seu metabolismo, como mecanismos de transporte de açúcar, regulação da geração de butanol, tolerância ao butanol, inibição pelos subprodutos de degradação e produção de enzimas que atuem em etapas específicas da reação. (EZEJI, 2007). Tecnologias de recombinação de DNA têm sido usadas juntamente com mutagênese tradicional para alterar as rotas metabólicas dos microorganismos. (TUMMALA, 2003).

Outras variações de processos incluem 0 uso de diferentes microorganismos, como Eschericchia Coli (NEXANT, 2006a). Uma das principais dificuldades no seu emprego está em sua limitação para converter alguns tipos de açúcares usualmente encontrados juntamente com a glicose (CONTAG, 2008). Esta é a estratégia inicial da empresa Gevo, um dos principais participantes no desenvolvimento e comercialização de tecnologia em biobutanol (GEVO, 2011). Este é um microorganismo de crescimento rápido e as ferramentas genéticas para sua modificação são bem conhecidas (JIN, 2011). Leveduras normalmente utilizadas para a produção de etanol, como a Saccharomyces cerevisae, são pesquisadas e modificadas por empresas como a Butalco (BUTALCO, 2012), e também exploradas pela Butamax.

\subsection{2 - Tecnologia de Reatores de Fermentação}

Os principais métodos utilizados para a condução da fermentação são descritos a seguir: (RANJAN, 2012)

- Fermentação em batelada: é o processo mais tradicional, consistindo basicamente de um vaso com agitação e outros acessórios, como camisa de aquecimento / resfriamento. O substrato e os nutrientes adicionais são carregados no reator, em concentrações típicas de 60 a 
$80 \mathrm{~g} / \mathrm{L}$. O reator é esterilizado a aproximadamente $120^{\circ} \mathrm{C}$, seguido de resfriamento a $35-37{ }^{\circ} \mathrm{C}$. Ele é então inoculado com os microorganismos. A condição anaeróbia do reator é mantida através da purga de nitrogênio ou $\mathrm{CO}_{2}$. O tempo típico para fermentação é de $48 \mathrm{~h}$ a $72 \mathrm{~h}$. Ao atingir uma concentração de $20 \mathrm{~g} / \mathrm{L}$ de butanol, o crescimento celular é interrompido e a fermentação cessa. Ao final, a massa celular e outros sólidos são removidos por centrifugação, e a porção líquida é enviada para a unidade de destilação.

- Fermentação em batelada alimentada: este processo fermentativo é empregado normalmente quando a concentração de substrato é tóxica aos microorganismos. O reator é iniciado no modo batelada com baixa concentração de substrato. Conforme o substrato é consumido, são realizadas cargas adicionais mantendo o nível abaixo da concentração tóxica. No caso da fermentação $A B E$, este processo tem sido utilizado em conjunto com a retirada de solventes.

- Fermentação contínua: nesta modalidade, a produtividade do reator pode ser otimizada. O reator pode ser em um único estágio, com alimentação de substrato e retirada contínua de solvente, ou ainda uma série de reatores em vários estágios, para contemplar os diversos estágios de acidogênese e solventogênese. Uma das dificuldades no uso de processo contínuo em processos biológicos está na flutuação dos níveis de produção.

Algumas variações na construção do reator permitem o aumento de produtividade, principalmente manipulando as células e concentrações de solvente para que não atinjam concentrações tóxicas aos microorganismos (KUMAR, 2011):

- Reator contínuo de célula imobilizada: alta concentração de microorganismos resulta em alta produtividade do reator. Nestes sistemas contínuos, o substrato é introduzido em um reator tubular ao fundo, com recuperação de solvente no topo. As células de microorganismos são imobilizadas em blocos de argila por adsorção. A produtividade chega a ser 40 a 50 vezes superior que em sistemas contínuos convencionais. 
- Reator contínuo com membranas: o reator é iniciado no modo batelada, e o crescimento celular é permitido. Antes que atinja sua fase estacionária, o caldo de fermentação é circulado através de uma membrana. Esta permite que a solução aquosa passe, enquanto retém as células. A alimentação do reator e o permeado são contínuos e uma taxa constante é mantida no reator. A saturação das membranas, contudo, tem sido um desafio neste processo.

Os reatores contínuos são conceitos ainda não demonstrados comercialmente. Eles apresentam diversos desafios para sua implementação, para o aumento de escala e manutenção das fermentações.

\subsection{3 - Técnicas de Recuperação de Solventes}

O processo tradicional de destilação, utilizado normalmente para recuperação de etanol, é considerado de alto custo para o butanol devido às baixas concentrações do produto em água. Desta forma, processos alternativos têm sido investigados para remover os solventes do processo, aumentando sua concentração na corrente aquosa que será destilada, reduzindo os custos da destilação final. Um benefício adicional destes processos é a possibilidade de remover o solvente continuamente do caldo de fermentação e desta forma contornar o problema da toxicidade do butanol aos microorganismos (JIN, 2011). Os principais processos estão descritos abaixo, e são posteriormente ilustrados na FIGURA 15:

- Extração por gás de arraste: esta é uma técnica simples para recuperação de solventes. Pode-se empregar nitrogênio ou gás carbônico como gás de arraste. Os próprios gases da fermentação $\left(\mathrm{CO}_{2}\right.$ e $\mathrm{H}_{2}$ ) podem ser recuperados e borbulhados no reator, capturado os solventes. Estes, por sua vez, são recuperados por condensação. $O$ gás é reciclado e enviado novamente ao reator. Uma variação deste processo tem sido largamente pesquisada por empresas e universidades. Utilizando vácuo para remoção dos solventes, é possível recuperar também o azeótropo formado pela água e butanol. processo denominado remoção de solvente in situ (in situ product removal, ou ISPR), foi descrito por MARIANO (2012). 
- Extração líquido-líquido: um solvente é adicionado ao caldo de fermentação, solubilizando butanol, acetona e etanol. Estes são posteriormente recuperados por destilação. Produtos utilizados nesta técnica incluem, por exemplo, decanol. Uma variação deste processo utilizando líquidos iônicos foi proposta por KAMINSKI (2011) para o problema da utilização de produtos de alta toxicidade na extração líquido-líquido.

- Perstração: diversos problemas estão associados com a extração líquido-líquido, incluindo a toxicidade do solvente extrativo para as células dos microorganismos. Neste processo, o caldo de fermentação e o líquido extrator são separados por uma membrana. A membrana proporciona uma grande área superficial, através da qual as duas fases imiscíveis podem trocar butanol (EZEJI, 2007). Como não há contato entre as duas fases, a toxicidade do líquido extrator não afeta o caldo de fermentação. A difusão de outros solventes também pode ser controlada seletivamente pela membrana, aumentando a concentração de butanol.

- Pervaporação: este é um processo baseado em membranas, que permite a remoção seletiva de compostos voláteis do caldo de fermentação. O solvente permeia pela membrana e é recuperado por destilação. A eficácia da separação depende da seletividade da membrana e do fluxo através da membrana (RANJAN, 2012). Estes são parâmetros chave no desenvolvimento de materiais de baixo custo, com seletividade adequada e alto fluxo, de maneira a permitir o uso da pervaporação no processo $A B E$ com baixo investimento de capital (GARCIA, 2011). 


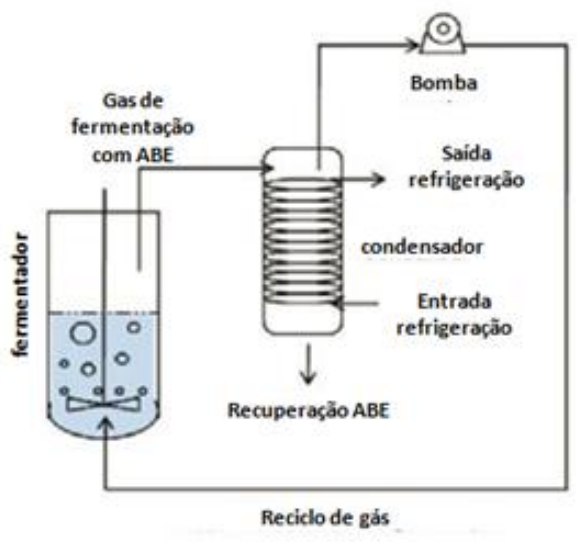

Gás de Arraste

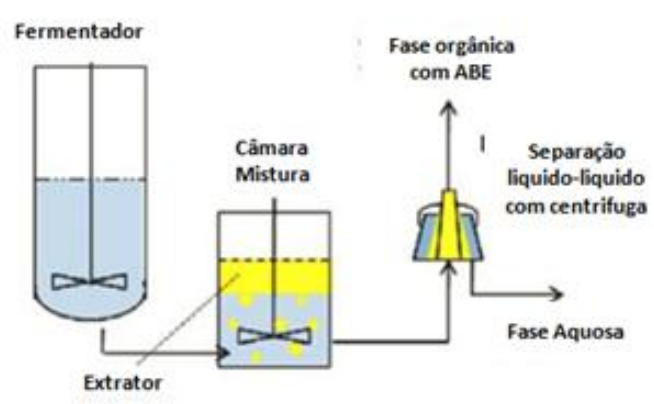

Extração Líquido-Líquido

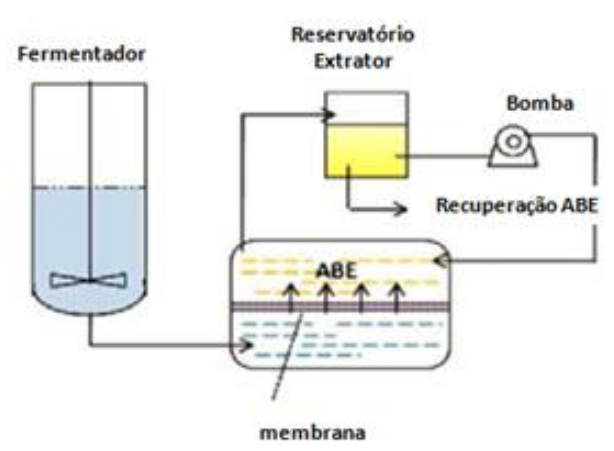

Perstração

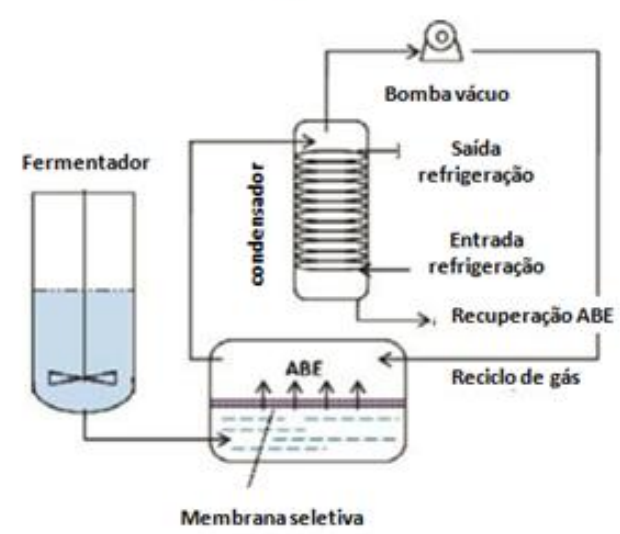

Pervaporação

FIGURA 15: Principais métodos de separação (adaptado de SUKUMARAN, 2011)

\section{9- Butanol como combustível}

\subsection{1 - Biocombustíveis}

Os biocombustíveis tem sido considerados por muitos países como alternativas aos combustíveis provenientes de fontes fósseis, equilibrando 0 desenvolvimento econômico com as preocupações ambientais. Temas como aquecimento global, disponibilidade e preço das matérias primas fósseis, fomentam a discussão pública, e dirigem ações das empresas e formadores de políticas em busca de soluções viáveis (FROST \& SULLIVAN, 2008a).

É comum encontrar referências ao desenvolvimento de biocombustíveis em "gerações". Pode-se adotar as definições constantes na TABELA 2, baseados na fonte de carbono da qual o combustível é derivado (EUROPA, 2013): 
TABELA 2: descrição das gerações de biocombustíveis (elaboração própria, adaptado de FROST \& SULLIVAN 2008b)

\begin{tabular}{lll}
\hline Classificação Adotada & Definição & Exemplos \\
\hline Primeira Geração & Obtidos por conversão direta & Bioetanol, biobutanol, \\
& dos açúcares (cana), amido & biogás, biodiesel \\
de milho, amido de batata, & \\
& óleo vegetal, obtidos & \\
& diretamente da planta. & \\
Segunda Geração & Combustíveis provenientes da & Bioetanol e biobutanol \\
& conversão da biomassa & (celulósicos) \\
& lignocelulósica (bagaço de & \\
& cana, sabugo de milho, palha & \\
& de trigo, madeira), após & \\
& tratamento por Hidrólise ou & \\
& Pirólise & \\
& & \\
& Derivados de algas por & Biodiesel de algas, \\
& gaseificação, extração de & bioetanol, biobutanol \\
& óleos ou hidrólise da porção & (celulósicos) \\
& lignocelulósica & \\
\hline Terceira Geração & & \\
& &
\end{tabular}

As classificações em diferentes gerações contemplam o balanço entre necessidades imediatas e em longo prazo, tais como:

- aumentar a segurança energética e reduzir dependência de combustíveis fósseis;

- atendimento a normas e regulamentações ambientais

- aumento de produtividade e rendimento para desenvolver rotas sustentáveis.

Especificamente no Brasil, o etanol tem sido utilizado como combustível de maneira continuada deste a década de 70 . O programa Proálcool, estabelecido em 1975, objetivou a redução da dependência do petróleo importado pelo país. Durante os primeiros 10 anos do programa, o objetivo foi a utilização do etanol 
como combustível alternativo à gasolina. $\mathrm{O}$ crescimento foi significativo, auxiliado por subsídios governamentais. Por volta de 1988, praticamente $90 \%$ dos carros nacionais eram movidos exclusivamente a etanol. Neste período, contudo, o governo liberou as exportações de açúcar para aproveitar os altos preços internacionais. Este fato, aliado à retirada de subsídios do etanol e ao baixo preço do petróleo, levou à escassez de etanol. A demanda por carros movidos exclusivamente a etanol reduziu drasticamente até 2003. Após este período, os preços de etanol voltaram a ser competitivos. A introdução dos veículos flex nesta fase, movidos a etanol ou gasolina, levou à retomada do crescimento da produção de etanol (FROST \& SULLIVAN, 2006).

Legislações específicas em muitos países defendem 0 uso de biocombustíveis (BORSCHIVER, 2011):

- Estados Unidos: Mandato para incremento gradativo do uso de biocombustíveis até 2022, com potencial de uso de até 130 bilhões de litros por ano. Incentivos para produtores de etanol e biocombustíveis celulósicos. Investimento em pesquisa de produtos de $2^{\underline{a}}$ geração.

- China: Plano quinquenal de substituição de importações, adicionando 1 bilhão de litros de etanol anuais. Desenvolvimento de tecnologias de $2^{\mathrm{a}}$ geração. Investimento em países com alta disponibilidade de matérias primas.

- União Europeia: Metas para uso de biocombustíveis de 5,75\% em 2010 e $10 \%$ em 2020. Busca de fontes baseadas em matérias primas não alimentícias. Elevados subsídios para os produtores.

- Índia: Metas de substituição de 5\% dos combustíveis fósseis em 2010, com incremento para 10\% em 2017 e 20\% em longo prazo.

- Brasil: Meta de $5 \%$ de biodiesel adicionado ao diesel convencional e $25 \%$ de etanol adicionado à gasolina. Motores automotivos flexíveis para uso com gasolina ou etanol. 


\subsection{2 - Butanol como biocombustível}

O Brasil já utiliza o bioetanol como combustível há várias décadas. O processo fermentativo é simples e robusto. A infraestrutura de distribuição e os motores dos automóveis já estão convertidos ao bioetanol. Outros países definem agora suas políticas e estratégias de longo prazo para biocombustíveis. Neste aspecto, o etanol possui algumas propriedades indesejáveis como, por exemplo, sua afinidade pela água, o que torna custoso o processo de destilação e dificulta seu transporte por tubulações. Além disso, é corrosivo e evapora facilmente. Alguns países ainda dependem predominantemente de gasolina e diesel. Ao se avaliar as diferentes alternativas para substituição de gasolina, tanto n-butanol quanto isobutanol têm propriedades muito desejáveis para uso como biocombustíveis. Quando comparado ao etanol, o butanol apresenta uma série de vantagens (NEJAME, 2010):

- O butanol tem um conteúdo energético de $33,81 \mathrm{MJ} / \mathrm{kg}$, maior do que o do etanol que é apenas $26,8 \mathrm{MJ} / \mathrm{kg}$. O conteúdo energético de um álcool eleva-se com o incremento do número de carbonos. O butanol tem quatro carbonos contra apenas dois do etanol, e o maior conteúdo energético permite uma maior autonomia, com aumento de quilometragem rodada para um mesmo volume de combustível (JIN, 2011).

- O butanol é compatível com os sistemas de distribuição de combustível existentes para gasolina. Ele é compatível com as tubulações, e menos corrosivo que etanol. Por ser menos hidrofílico que o etanol, ele absorve menos água. Misturas de butanol e gasolina estariam menos sujeitas à separação de fases que misturas de etanol e gasolina quando contaminadas com água.

- O butanol é compatível com motores a gasolina existentes, não necessitando de adaptação ou modificação. A empresa Butamax já realizou testes com 250.000 veículos em um total de 125 milhões de quilômetros rodados. (CARMANN, 2011).

- Menos corrosivo que o etanol, em particular para o alumínio. Isto é especialmente importante para os motores que irão utilizar este combustível sem modificações. 
- Em relação à solubilidade, quanto maior a cadeia carbônica de um álcool, mas fácil será sua solubilização em diesel ou gasolina, sem a necessidade de adição de co-solventes.

- O butanol tem menor pressão de vapor e ponto de fulgor mais elevado que o etanol, sendo, portanto, mais seguro para manuseio, uso e estocagem.

- Em estudos de laboratório, foi observado o efeito sinérgico de butanol na biodegradação de combustíveis em solo e água, em misturas de $20 \%$ butanol/gasolina e $20 \%$ butanol/diesel. (SOUZA, 2009).

Os isômeros de butanol apresentam átomos de carbono organizados em cadeias lineares ou ramificadas e diferentes localizações do grupo hidroxila na cadeia carbônica. As diferentes estruturas têm impacto nas propriedades físicas, que estão resumidas na TABELA 3. Embora a maioria das propriedades de interesse para combustíveis sejam similares, existem diferenças entre os dois isômeros que são normalmente obtidos por rotas biológicas, ou seja, n-butanol e isobutanol. O isobutanol apresenta uma maior octanagem que o $\mathrm{n}$-butanol. Isto se constitui uma vantagem, principalmente ao considerarem-se as misturas com gasolina/butanol. $O$ isobutanol apresenta propriedades mais próximas a este combustível, contribuindo para o bom desempenho dos motores. Os outros isômeros, sec-butanol e o terc-butanol, não são produzidos por fermentação. A TABELA 4 compara as principais propriedades de interesse para biocombustíveis. 
TABELA 3: Propriedades comparativas entre isômeros de butanol (elaboração própria, com base em JIM, 2011)

\begin{tabular}{|l|c|c|c|c|c|}
\hline \multicolumn{1}{|c|}{ Propriedade } & Unidade & n-butanol & sec-butanol & terc-butanol & isobutanol \\
\hline $\begin{array}{l}\text { Densidade } \\
\text { Numero de Octano } \\
\text { (teórico) }\end{array}$ & $\mathrm{g} / \mathrm{cm}^{3}$ & 0,810 & 0,810 & 0,789 & 0,802 \\
\hline $\begin{array}{l}\text { Número de Octano } \\
\text { (Motor) }\end{array}$ & $\mathrm{RON}$ & 96 & 101 & 105 & 113 \\
\hline & $\mathrm{MON}$ & 78 & 32 & 89 & 94 \\
\hline $\begin{array}{l}\text { Ponto de Ebulição } \\
\text { Viscosidade a } 25^{\circ} \mathrm{C}\end{array}$ & $\mathrm{o} \mathrm{C}$ & 117,7 & 99,5 & 82,4 & 108,0 \\
\hline
\end{tabular}

TABELA 4: Propriedades de interesse para combustíveis (elaboração própria, com base em JIM, 2011)

\begin{tabular}{|c|c|c|c|c|c|}
\hline Propriedade & Unidade & Gasolina & Diesel & Etanol & n-Butanol \\
\hline Fórmula molecular & & $\mathrm{C}_{4}-\mathrm{C}_{12}$ & $\mathrm{C}_{12}-\mathrm{C}_{25}$ & $\mathrm{C}_{2} \mathrm{H}_{12} \mathrm{OH}$ & $\mathrm{C}_{4} \mathrm{H}_{9} \mathrm{OH}$ \\
\hline Densidade & $\mathrm{g} / \mathrm{cm}^{3}$ & $0,72-0,78$ & $0,82-0,86$ & 0,79 & 0,81 \\
\hline Número de Cetano & & $0-10$ & $40-55$ & 8 & 25 \\
\hline Número de Octano & & $80-99$ & $20-30$ & 108 & 96 \\
\hline $\begin{array}{l}\text { Conteúdo de } \\
\text { Oxigênio }\end{array}$ & $\%$ & - & - & 34.80 & 21.60 \\
\hline Viscosidade a $40^{\circ} \mathrm{C}$ & $\mathrm{mm}^{2} \mathrm{~s}^{-1}$ & $0.40-0.80$ & $1.90-4.10$ & 1.08 & 2.63 \\
\hline Ponto de Fulgor & ${ }^{\circ} \mathrm{C}$ & $-40 a-38$ & $65-88$ & 8 & 35 \\
\hline Ponto de Ebulição & ${ }^{\circ} \mathrm{C}$ & $25-215$ & $180-370$ & 78 & 118 \\
\hline Poder Calorífico & $\mathrm{MJ} / \mathrm{kg}$ & 42,7 & 42,5 & 26,8 & 33,1 \\
\hline
\end{tabular}




\subsection{3 - Oportunidades para o biobutanol}

O biobutanol tem atraído o interesse como combustível devido à necessidade de produção de grandes volumes de biocombustíveis para cumprir com os requisitos regulatórios de diversos mercados. Por exemplo, nos Estados Unidos, o Padrão para Combustíveis Renováveis (Renewable Fuel Standard RFS) de 2005 determina a adição de biocombustíveis à gasolina. O U.S. Energy Independence and Security Act (EISA) de 2007, também conhecido como RFS2, estabelece percentuais mínimos a serem adotados gradativamente no combustível norte-americano. O volume necessário estimado é de um consumo crescente até atingir 136 bilhões de litros de biocombustíveis a serem usados anualmente no mercado americano em 2022. Embora o RFS2 determine a utilização de biocombustíveis, ele não autoriza a alteração dos motores dos veículos para que utilizem uma maior porcentagem de etanol. A atual frota norteamericana não está preparada para receber uma alta percentagem de etanol misturada à gasolina, pois pode haver perda de eficiência e rendimento. O maior conteúdo de oxigênio no etanol exige uma compensação do sistema de injeção para uma queima correta. Também podem haver danos às partes metálicas ou poliméricas do motor e seus sistemas acessórios. Um aumento de $5 \%$ do uso de etanol de E10 para E15 pode subir a temperatura dos gases de exaustão em $5{ }^{\circ} \mathrm{C}$ a $10^{\circ} \mathrm{C}$. Veículos com o conceito Flex chegaram a ser comercializados os Estados Unidos, utilizando um combustível com $85 \%$ de etanol (E85), porém houve baixa aceitação pelo consumidor (DOE, 2013).

A maior parte dos 240 milhões de veículos norte americanos foi desenhada para utilizar gasolina, ou misturas de gasolina com até $10 \%$ de bioetanol (E10). Concentrações maiores que $10 \%$ de bioetanol podem causar danos aos motores dos veículos. A Agência Ambiental Americana (Environmental Protection Agency - EPA) estuda a permissão de uma adição de $15 \%$ de etanol (E15) para veículos que foram fabricados a partir de 2001. Esta mudança é complexa, pois demandaria uma nova rede de distribuição, com bombas de gasolina específicas para E15. Contudo, mesmo o E15 seria suficiente para permitir o uso de etanol somente até 2016. Este limite é conhecido como Blending Wall. Acima disto, seria necessário efetuar alterações na infraestrutura de distribuição e nos motores para permitir o uso de bioetanol. Neste contexto, o biobutanol, em substituição ao 
etanol como biocombustível, poderia ser utilizado sem restrições para mistura à gasolina. Com o biobutanol, é possível adicionar até $24 \%$ de combustível renovável à gasolina, mantendo o mesmo desempenho (CARMANN, 2011).

A produção atual de bioetanol nos EUA com fonte em milho é de 40 bilhões de litros. O etanol brasileiro, proveniente de açúcar da cana-de-açúcar, é uma alternativa para os Estados Unidos suprirem parte do volume restante necessário. O bioetanol brasileiro reduz emissões de gases e efeito estufa (GHG) em 78\%, e redução do uso de energia derivada de fontes fósseis em 97\% quando comparado com a gasolina (WANG, 2008). Estes dados consideram o ciclo completo desde a produção de fertilizantes, plantio e colheita da cana, transporte para a usina, produção de álcool, transporte para os Estados Unidos, distribuição para as bombas de combustível e uso nos veículos. Estima-se que a eliminação das queimadas para colheita de cana contribua com uma redução adicional de 9\% de emissões quando comparada com a gasolina. (WANG, 2008).

A própria Agência Ambiental Americana (EPA) reconhece que somente o etanol, conforme produzido hoje derivado de milho, não será capaz de suprir a demanda por biocombustíveis. Devido a isto, existe intenso investimento em pesquisas de processos de hidrólise de material lignocelulósico, assim como procura pelo uso de outros biocombustíveis além do bioetanol. Isto inclui o biobutanol como combustível alternativo (EPA, 2010).

Na Europa, existem diretivas que cobrem o uso de biocombustíveis. Estas incluem a Diretiva de Energia Renovável 2009/28/EC (Renewable Energy Directive), a Diretiva de Qualidade de Combustíveis (Fuel Quality Directive), e a Diretiva de Biocombustíveis 2003 (Biofuels Directive). Em 2013, a Comissão Europeia (European Commission), publicou a COM(2013)17: Energia Limpa para Transporte: Uma Estratégia Alternativa Europeia para Combustíveis (Clean Power for Transport: A European Alternative Fuels Strategy) (EUROPA 2013).

Esta iniciativa defende o desenvolvimento sustentável de biocombustíveis avançados produzidos de biomassa lignocelulósica e resíduos agrícolas, e também algas, ou seja, segunda e terceira geração. Ela suporta o uso de biocombustíveis de primeira geração somente até 2020, pois estes podem oferecer risco de desabastecimento de alimentos (EUROPA, 2013). 
No Brasil, o Programa Nacional do Álcool - Proálcool foi instituído pelo Decreto $\mathrm{N}^{\circ} 76.593$ de 14 de novembro de 1975. A fase 1 do Proálcool utilizou o etanol como aditivo da gasolina, e na fase 2, a partir de 1979, o combustível foi utilizado $100 \%$ em carros dedicados ao uso de etanol. Atualmente a regulamentação exige o uso de etanol anidro entre 18 e $25 \%$ adicionado à gasolina, ou a comercialização do etanol hidratado. Já a Lei $\mathrm{N}^{0} 11.097$, de 13 de janeiro de 2005, foi criada com o objetivo de introduzir o uso do biodiesel com volume de substituição de $2 \%$ do petro-diesel entre 2008 e 2012 , e $5 \%$ a partir de 2013 (ANP, 2013).

A incorporação de combustíveis renováveis à matriz de energética é uma meta buscada por vários países. Desta forma, existe uma oportunidade clara para o biobutanol, seja no mercado americano para suprir o consumo interno, assim como para o mercado brasileiro como base exportadora para os Estados Unidos e outros países. O biobutanol é um potencial substituto para a gasolina, e também pode ser adicionado ao diesel em quantidades significativas (HARVEY, 2010). O biobutanol atrai o interesse imediato devido às suas boas propriedades como elevado poder calorífico, baixo ponto de congelamento, baixa higroscopicidade, e taxa de vapor que são mais próximas à gasolina que outros biocombustíveis (KUMAR, 2012).

3.10 - Empresas participantes no desenvolvimento de biobutanol

Existem atualmente diversas empresas atuantes no desenvolvimento de tecnologias para biobutanol. Algumas destas empresas caracterizam-se pelo foco em biotecnologia e desenvolvimento de processos. Muitas das empresas emergentes foram adquiridas ou efetuaram joint-ventures com empresas tradicionais na fabricação de petro-butanol ou combustíveis, de maneira a obter sinergia. Algumas destas empresas estão listadas abaixo (MASCAL, 2012):

GEVO: Empresa norte-americana, atuando no desenvolvimento de processos e microorganismos. Seu foco é a conversão de fábricas de bioetanol para biobutanol nos Estados Unidos. Recebe recursos da Cargill, grupo Total (França) e tem acordos com o produtor de borrachas Lanxess. Propõe uma tecnologia chamada GIFT(r) (Gevo Integrated Fermentation Technology). Seus desenvolvimentos iniciais foram baseados em modificações da bactéria E.Coli 
com enzimas que convertessem ácidos em aldeídos e aldeídos em butanol. Após sucessivas modificações, a empresa defende ter obtido um processo com alto rendimento de isobutanol.

Butamax: Empresa formada a partir da joint-venture da British Petroleum (BP) e da Dupont. Possui atualmente 150 funcionários ao redor do mundo dedicados ao desenvolvimento e comercialização de isobiobutanol. Sua estratégia envolve a conversão de usinas de etanol a butanol (retrofit).

Cobalt Technologies: Empresa dedicada ao estudo de processos empregando matérias primas não alimentícias e desenvolvimento de processos produtivos. Recentemente divulgou sua parceria com a Rhodia no Brasil para a produção de n-butanol.

Butyl Fuel: Empresa de biotecnologia e químicos renováveis, conhecida também por ser uma das primeiras empresas a divulgar o potencial do n-butanol como combustível em 1992. Associou-se recentemente à Green Biologics, uma empresa britânica fundada em 2003 e especializada em fornecer soluções para conversão de plantas de bioetanol a biobutanol.

Tetravitae Bioscience: Empresa de biotecnologia, reconhecida por seus conhecimentos em processos fermentativos utilizando Clostridia. Foi recentemente adquirida pela Eastman, um tradicional fabricante de produtos químicos.

Cathay Industrial Biotech: Empresa baseada em Xangai, iniciou sua produção em 2009 com capacidade demonstrada de 75.000 toneladas e vendas de 20.000 toneladas em 2010. Utiliza fermentação ABE contínua e possui planta de demonstração para produção de bioetanol celulósico a partir de sabugo de milho.

HC Sucroquímica: Em operação desde 2006 no município de Campos-RJ, adjacente à Usina Paraíso, produz acetona e biobutanol. A produção estimada é de 2.000 toneladas anuais direcionados ao segmento de especialidades químicas. 
A TABELA 5 apresenta um resumo das principais empresas e suas respectivas tecnologias produtivas, relacionando também o tipo de isômero de butanol produzido, e as principais características do processo fermentativo e separação de solventes:

TABELA 5: Principais empresas atuando em biobutanol e suas respectivas tecnologias (adaptado de NEJAME, 2010).

\begin{tabular}{|c|c|c|c|c|c|}
\hline Empresa & Microorganismo & Estratégia & Molécula & $\begin{array}{c}\text { Processo } \\
\text { Fermentativo } \\
\end{array}$ & $\begin{array}{c}\begin{array}{c}\text { Estratégia de } \\
\text { Separação }\end{array} \\
\end{array}$ \\
\hline GEVO & E.Coli & GMO & Isobutanol & semi-contínuo & $\begin{array}{l}\text { remoção a vácuo in } \\
\text { situ seguida de } \\
\text { destilação }\end{array}$ \\
\hline Butamax (Dupont/BP) & \begin{tabular}{|l} 
Clostridia \\
E.coli \\
\end{tabular} & GMO & Isobutanol & semi-contínuo & $\begin{array}{l}\text { remoção in situ } \\
\text { seguida de destilação }\end{array}$ \\
\hline Cobalt Biofuels & Clostridia & $\begin{array}{l}\text { não GMO, acetona e } \\
\text { etanol reduzidos }\end{array}$ & n-butanol & $\begin{array}{l}\text { ABE modificada, } \\
\text { contínuo }\end{array}$ & $\begin{array}{l}\text { remoção com vapor e } \\
\text { destilação }\end{array}$ \\
\hline Green Biologics (UK) & mistura de Clostridia & $\begin{array}{l}\text { GMO de alta } \\
\text { tolerância (4\%) }\end{array}$ & n-butanol & fermentação contínua & $\begin{array}{l}\text { remoção in situ } \\
\text { seguida de } \\
\text { destilação }\end{array}$ \\
\hline Butyl Fuel & Clostridia & GMO e mutações & n-butanol & \begin{tabular}{|l|} 
fermentação contínua \\
reator de dois \\
estágios
\end{tabular} & $\begin{array}{l}\text { stripping e reator de } \\
\text { célula imobilizada }\end{array}$ \\
\hline Tetra Vitae (Eastman) & C. beijerinckii & $\begin{array}{l}\text { não GMO, etanol } \\
\text { reduzido }\end{array}$ & $\begin{array}{l}\text { n-butanol e acetona } \\
2: 1\end{array}$ & batelada "AB" & $\begin{array}{l}\text { extração com } \mathrm{CO} 2 \\
\text { continua in situ } \\
\text { seguida de destilação }\end{array}$ \\
\hline Cathay & Clostridia & migrando para GMO & n-butanol & $\begin{array}{l}\text { migrando do } \\
\text { processo ABE } \\
\text { convencional }\end{array}$ & remoção in situ \\
\hline
\end{tabular}




\section{Desenvolvimento do Projeto de Pesquisa}

Neste capítulo são descritos os aspectos relativos à metodologia de pesquisa utilizada para a construção do Technology Roadmap de Biobutanol no Brasil. São apresentadas as etapas adotadas para construção do instrumento de pesquisa e sua validação, assim como a sistemática de condução das entrevistas, análise dos resultados e construção do mapa final.

A revisão bibliográfica efetuada no capítulo 3 apresentou em sua primeira parte a conceituação dos technology roadmaps. Foram revisadas as metodologias propostas por diversos autores, e apresentados os exemplos de aplicação dos roadmaps na construção de planos estratégicos nacionais e no setor de energia. Foram revisados exemplos específicos de roadmaps elaborados para o setor de bioenergia, incluindo estudos no Brasil onde foi aplicada a metodologia para visualização do progresso tecnológico e definição de prioridades de investimento e pesquisa.

Ainda no capítulo 3, foi apresentado o histórico de pesquisa em biobutanol. Apresentou-se o crescente aumento de interesse no aperfeiçoamento de seu processo de obtenção para uso como biocombustível, em substituição à gasolina ou em uso conjunto a esta, a fim de cumprir com as legislações de redução de uso de combustíveis fósseis em diversos países. O processo atualmente ainda apresenta baixo rendimento, e sua viabilidade econômica depende do avanço em microbiologia, controle de processo, uso de fontes de matéria prima de maior volume e menor custo. O potencial do produto tem atraído o interesse e investimento de empresas, sejam tradicionais empresas químicas ou de biotecnologia, assim como start-ups atraindo capital especulativo.

Uma das principais características da metodologia de technology roadmapping é a sua flexibilidade, permitindo que o processo seja adaptado às necessidades do tema em questão, possibilitando o fluxo de informações e o aprendizado durante o processo de construção do mapa. Para elaboração deste Technology Roadmap de Biobutanol, foi utilizada a metodologia proposta por PHAAL, FARRUKH e PROBERT (2001a e 2001b). No método utilizado pelos pesquisadores na Universidade de Cambridge, Centro de Gerenciamento Tecnológico, são propostos seminários para aquisição de dados, discussão e 
troca de informações entre especialistas em aspectos relativos a quais mercados devem ser atendidos no futuro e quais suas principais necessidades, os produtos e o prazo em que deverão estar prontos para atender a estes mercados, assim como as tecnologias que deverão ser utilizadas ou desenvolvidas no momento adequado para produzir os produtos e atender aos mercados.

Para que o processo de condução dos seminários tenha sucesso, assim como a elaboração do mapa final, alguns fatores são apontados como necessários:

- Definição clara dos objetivos;

- Comprometimento da liderança da organização, apoiando o processo;

- Um especialista na metodologia para facilitar o processo;

- Envolvimento de especialistas de funções diferentes;

- Criação de ambiente colaborativo;

- Comunicação efetiva dos resultados;

- Verificações periódicas para checar à necessidade de ajustes no plano.

O facilitador do processo precisa ter o domínio das técnicas e ferramentas para condução do roadmapping, assim como habilidade interpessoal, porém não necessariamente precisa ser um especialista no assunto a ser estudado. Esta capacidade deve residir no grupo de especialistas desenvolvendo o roadmap, de modo que seu envolvimento e compromisso são cruciais (GARCIA e BRAY, 1997).

O método Fast Track proposto por PHAAL (2001b) indica como seus principais objetivos:

- Suportar a familiarização com a metodologia.

- Estabelecer conexões chave entre os recursos tecnológicos e seus direcionadores.

- Identificar lacunas importantes quanto a mercados, produtos e inteligência tecnológica.

- Desenvolver uma primeira versão de um roadmap.

- Suportar estratégias tecnológicas e planejamento de um setor.

- Comunicar uma visão comum sobre o tema. 
O processo de roadmapping é baseado em quatro fases, que tomam a forma de seminários onde os especialistas participam e colaboram com suas ideias para discutir sobre mercado, produto, tecnologias, e elaboração do documento final. O processo é flexível quanto a tempo, recursos e foco. Os seminários podem ser estendidos ou comprimidos dependendo da informação disponível e do tema em análise (PHAAL, 2001b). Partindo desta premissa, o presente trabalho propõe:

A prospecção tecnológica do biobutanol no contexto brasileiro de biocombustíveis. Para este objetivo, é adotado o uso de entrevistas individuais com especialistas no tema, geralmente membros de empresas, institutos de pesquisa ou universidades com atuação destacada na pesquisa e desenvolvimento de biocombustíveis, e biobutanol integrado ao conceito de biorrefinarias.

O uso de entrevistas para condução do roadmapping é uma adaptação do método pesquisa-ação. THIOLLENT (1997) sugere uma abordagem para intervenção em organizações, voltada para a definição de meios de produção de produtos ou serviços. Esta abordagem é dividida em quatro fases: a) fase exploratória, onde é feito um diagnóstico do tema, b) pesquisa aprofundada, utilizando instrumento de coleta de dados, c) fase de ação, onde os resultados são divulgados, são definidos objetivos e estabelecidas ações, e finalmente d) fase de avaliação das ações e avaliação final.

No presente trabalho a fase exploratória foi cumprida através do levantamento dos dados secundários e informações disponíveis na literatura, através da revisão bibliográfica. A pesquisa aprofundada corresponde à pesquisa de campo, com entrevistas com atores no segmento de biobutanol no Brasil, em substituição aos seminários presenciais propostos por PHAAL (2001b). A fase de ação engloba a elaboração do technology roadmap para biobutanol. No escopo do presente trabalho não está englobada a implementação de ações tampouco intervenção nas organizações e sua avaliação.

A metodologia de pesquisa adotada é representada na FIGURA 16. A revisão bibliográfica incluiu a análise de artigos sobre o technology roadmap, de 
maneira a identificar os principais autores e efetuar comparação crítica de suas propostas. Na seção sobre biobutanol, foram avaliadas as informações disponíveis sobre biocombustíveis, como o biobutanol situa-se neste contexto, o estado da arte de suas tecnologias produtivas e os aspectos legais relacionados à sua implementação.

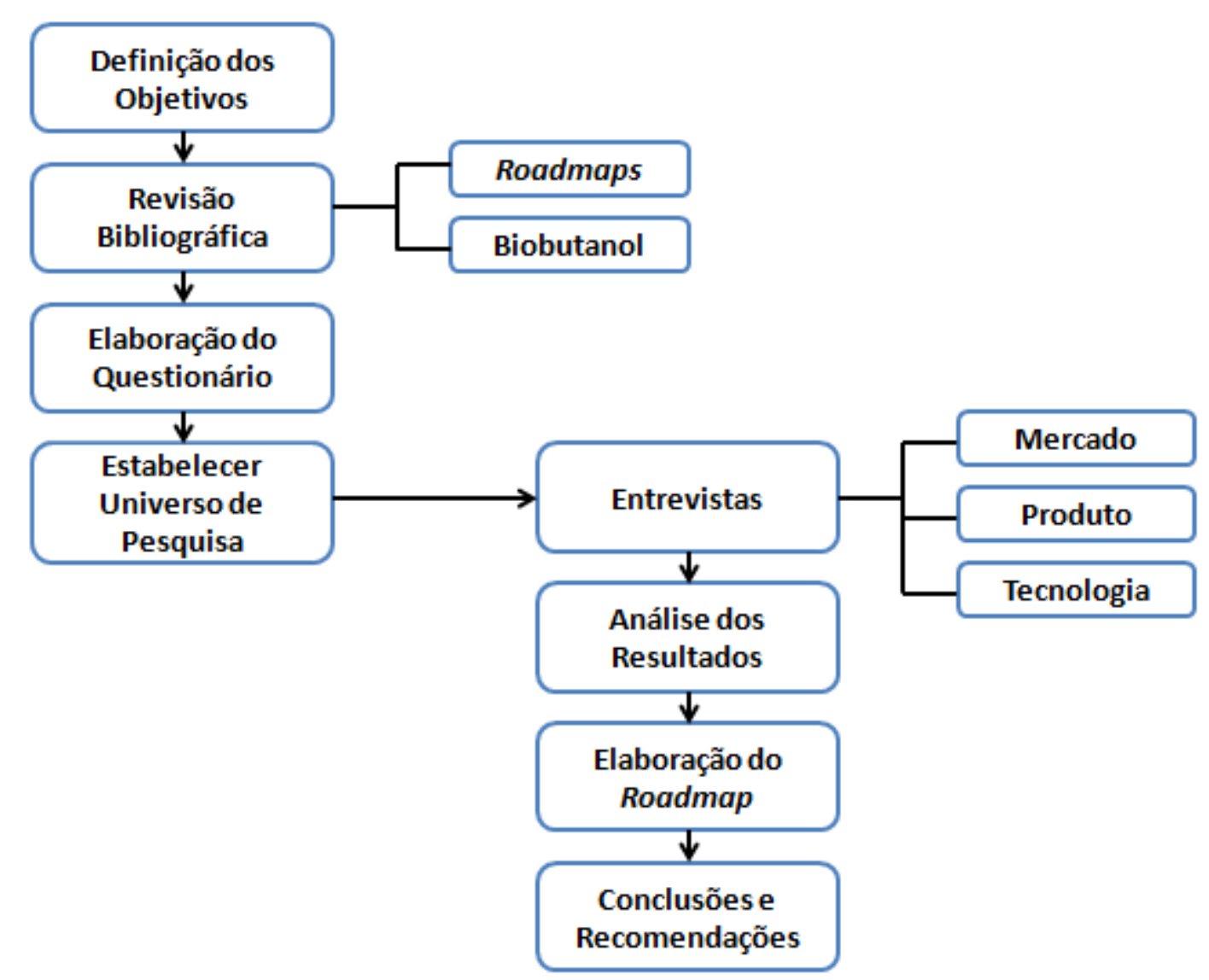

FIGURA 16: Fluxograma da metodologia de pesquisa (elaboração própria)

$\mathrm{Na}$ etapa de revisão bibliográfica, foram utilizadas ferramentas para levantamento de informações preliminares, com o objetivo de fornecer o direcionamento inicial sobre os principais autores, linhas de pesquisa, principais publicações e tendências tecnológicas. Inicialmente utilizou-se a busca por documentos científicos através da ferramenta Science Direct (ELSEVIER, 2012). As principais estratégias de busca utilizadas estão ilustradas na TABELA 6.

A pesquisa inicial revelou um grande número de roadmaps. Ao restringir-se a pesquisa utilizando as demais palavras-chave, foi possível chegar a um número razoável de documentos, permitindo a revisão dos resumos de todos os artigos. 
Foi efetuada uma análise exploratória para identificar trabalhos dos principais autores da área. A partir daí, foram utilizadas ferramentas para aquisição dos principais artigos e sua análise completa. Foram identificadas as principais revistas de interesse para a área, conforme registrado na TABELA 7.

TABELA 6: Principais resultados da busca inicial por artigos relativos a technology roadmaps (elaboração própria).

\begin{tabular}{ll}
\hline Palavras Chave & Número de Resultados \\
\hline Technology roadmap & 15641 \\
Technology roadmap energy & 8661 \\
Technology roadmap renewable energy & 2314 \\
Technology roadmap bioenergy & 1136 \\
Technology roadmap biofuels & 853 \\
Technology roadmap butanol & 106 \\
Technology roadmap biobutanol & 13 \\
Biobutanol & 336 \\
\hline
\end{tabular}

TABELA 7: Principais periódicos utilizados para a pesquisa bibliográfica (elaboração própria).

\begin{tabular}{lll}
\hline Nome do Periódico & ISSN & $\begin{array}{l}\text { Classificação } \\
\text { Qualis }\end{array}$ \\
\hline Technological Forecasting and Social Change & $0040-1625$ & A1 \\
Research and Technology Management & 0895.6308 & B1 \\
Journal of Cleaner Production & $0959-6526$ & A2 \\
Applied Energy & $0306-2619$ & A1 \\
Renewable \& Sustainable Energy Reviews & $1364-0321$ & A1 \\
Journal of Tech. Management \&Innovation & $0718-2724$ & A2 \\
Journal of Product Innovation Management & $0737-6782$ & B1 \\
\hline
\end{tabular}

Em relação ao tema biobutanol, o mesmo site de busca utilizado anteriormente trouxe 336 indicações de artigos relevantes ao tema. Estes artigos abordam principalmente os aspectos de obtenção, manipulação de 
microorganismos, e purificação do butanol. Artigos selecionados foram obtidos para leitura e avaliação na íntegra.

A TABELA 8 lista as principais ferramentas de busca utilizadas para obtenção de cópias de artigos, capítulos de livros, assim como bancos de dados de patentes, capacidades produtivas, análise de mercado e tendência de preços.

TABELA 8: Principais ferramentas de busca para obtenção de dados secundários (elaboração própria)

\begin{tabular}{ll}
\hline Ferramenta de Busca & Descrição \\
\hline Knovel & Acesso a livros texto da área de \\
www.knovel.com & engenharia
\end{tabular}

Sci Finder

www.cas.org/products/scifinder

IHS (CMAI)

www.ihs.com

Science Direct

www.sciencedirect.com

Thomson Reuters

(Thomson Innovation)

www.thomsonreuters.com
Busca de artigos publicados em periódicos, com foco na área de química. Foram obtidos 1622 artigos utilizando-se a palavras chave "butanol and fuel". A palavra chave "biobutanol" encontrou 243 artigos.

Dados históricos e previsão de comportamento de preços de produtos, em diversos mercados. Acesso a dados de capacidade instalada e produção e empresas em todos os países.

Busca e obtenção de artigos científicos, publicados pela editora Elsevier.

Pesquisa de patentes, com acesso a bancos de dados de diversos escritórios de patentes ao redor do mundo.

Como parte do processo de coleta de informações, foi elaborada também uma pesquisa de patentes utilizando a ferramenta Thomson Innovation. Sendo o 
butanol um solvente de largo uso industrial, incluindo nas indústrias de tintas, farmacêutica e cosmética, uma busca simples pela palavra chave [butanol] trouxe 50.000 registros no período de 1990 a 2012. Neste universo, os principais depositantes foram empresas produtoras como DuPont, Basf e Degussa, Bayer e Eastman, além usuários como Procter and Gamble, Teva Pharma e Oreal.

Uma busca simples pela palavra chave [biobutanol] traz 1.000 registros de 1990 a 2012. Decidiu-se então construir a árvore corporativa para cada depositante principal, combinando as duas estratégias de busca conforme abaixo:

- [ "BASF" OR "CIBASPEC" OR "COGNIS" OR "ENGELHARD" OR "HTEAG" OR "EVONICBATTERY" OR "SUNGENE" OR "CELANESE" OR "DUPONT" OR "DANISCO" OR "GENENCORN" OR "DUPONTEKCTECH" OR "PIOHIBRED" OR gevo OR cobalt OR butamax ]

- [ "biobutanol OR (butanol NEAR10 fuel) OR (butanol NEAR10 (renewable NEAR3 fuel))"]

É importante selecionar a busca restrita apenas aos títulos das patentes, reivindicações (claims) e resumos, pois é nestes campos que geralmente a invenção é descrita. Com esta estratégia, foram obtidas 127 patentes, sendo estas agrupadas em 41 famílias. Estes documentos foram selecionados e foi gerada uma tabela em planilha eletrônica para leitura de cada um dos resumos e reivindicações. O processo nesta etapa foi manual, pois a quantidade de documentos é pequena para construir um mapa de patentes baseado em agrupamento de textos (patent landscape / text clustering).

O questionário de pesquisa foi elaborado com base semi-estruturada. Nesta modalidade, o pesquisador segue um roteiro de perguntas pré estabelecidas, porém tem liberdade para desenvolver a situação em qualquer direção. É permitido adaptar as perguntas a uma determinada situação, alterar sua ordem, ou elaborar outras perguntas. É possível elaborar perguntas adicionais para explorar mais amplamente uma questão (MATTOS, 2005).

A elaboração do questionário de pesquisa, reproduzido no APÊNDICE A, contemplou três seções, correspondentes aos temas dos seminários tradicionais 
de roadmapping: mercados, produtos, tecnologias. O desenho e estruturação das perguntas, com base qualitativa, foi baseado em PROCTOR (2007).

O questionário de pesquisa inclui uma breve descrição sobre a proposta de trabalho, assim como seus objetivos. Uma cláusula de confidencialidade foi incluída, garantindo que os dados, conclusões e observações foram tratados pelo pesquisador de maneira agregada, sem referências diretas que identifiquem a sua fonte.

$\mathrm{Na}$ primeira parte do questionário, as perguntas relativas ao mercado objetivam coletar dados sobre os seguintes direcionadores:

- Utilização do produto: Biocombustível ou intermediário químico para uso industrial.

- Destino do produto: Mercado interno no Brasil ou exportação.

As perguntas relativas ao produto foram incluídas na segunda parte do questionário, buscando informações sobre os direcionadores relacionados abaixo. Esta seção incluiu ainda uma questão quantitativa para verificação da opinião dos especialistas quanto às propriedades mais importantes para uso do butanol como combustível.

- Rota de obtenção: processo petroquímico, biológico ou conversão térmica.

- Isômero: qual molécula deverá ser comercializada, n-butanol ou isobutanol.

A terceira e última parte do questionário foi elaborada com perguntas sobre as tecnologias empregadas para obtenção de biobutanol. Nesta etapa foram utilizados como direcionadores:

- A rota petroquímica existente e sua competitividade frente aos novos processos em desenvolvimento.

- A rota biológica, onde foram considerados como aspectos direcionadores principais as fontes de matéria prima para uso como 
substrato, os microorganismos para fermentação, o tipo de reator para fermentação, e o processo de separação dos solventes e destilação.

- A rota termoquímica, suas principais características e estágio de desenvolvimento.

Para a validação do questionário de pesquisas, foi conduzida uma entrevista inicial com uma das empresas participantes do desenvolvimento de biobutanol no Brasil. Esta entrevista foi conduzida em setembro de 2012, sendo importante para adequação da ordem das questões e clarificação da informação solicitada, principalmente nas perguntas relativas a método de separação de solventes. As correções necessárias foram incorporadas ao questionário.

O questionário de pesquisa foi aplicado a um público constituído por empresas nacionais e formadores de opinião tais como: produtores de petrobutanol, empresas desenvolvedoras de tecnologia em biobutanol, usuários de butanol (petro e bio-butanol), associações de classe, institutos de pesquisa e grupos de pesquisa, com o objetivo de identificar as áreas prioritárias de desenvolvimento na indústria nacional e situá-la no contexto internacional. Durante a condução das entrevistas, também foi realizada uma pesquisa de patentes, como parte do levantamento de dados, com o objetivo de identificar o estado da arte, os principais temas de pesquisa, e as principais empresas atuantes no setor de biobutanol.

Após as entrevistas, a informação coletada foi reunida, com realização de análise crítica dos dados. Com estes dados, conduziu-se o processo de technology roadmapping, com a construção de um mapa, estabelecendo a relação entre os dados e os direcionadores. $O$ documento final obtido retrata a perspectiva de evolução tecnológica para o biobutanol no Brasil em um período de tempo nos próximos 20 anos. 


\section{Pesquisa de Campo}

O objetivo principal da fase de pesquisa de campo foi o de entrevistar empresas participantes do mercado brasileiro e coletar informações para a validação das informações obtidas na literatura, permitindo o desenho do roadmap específico para posicionamento do biobutanol como combustível no Brasil. O questionário específico com questões cobrindo os aspectos de mercado, produto e tecnologias, conforme reproduzido no APÊNDICE A.

O universo da pesquisa incluiu as seguintes áreas de atuação: a) 03 empresas participantes no desenvolvimento de biobutanol, b) 01 empresa produtora de bioetanol, c) 01 empresa usuária de roadmaps para matérias primas renováveis, d) 03 empresas produtoras de butanol por rota petroquímica, ou usuárias de butanol como intermediário químico, e) 03 institutos de pesquisa, ou universidades de destacada atuação na área de bioenergia, f) 01 associação de classe na área de celulose e papel. A TABELA 9 lista as entidades envolvidas, e seus respectivos especialistas entrevistados.

Após o contato inicial por telefone ou correio eletrônico, as entrevistas foram realizadas pessoalmente com os especialistas. $O$ método seguiu o modelo semi-estruturado, com o roteiro de perguntas pré estabelecidas podendo ser adaptadas ou expandidas durante a interação. Uma das entrevistas ocorreu por telefone, com igual efetividade. A interação com a associação de classe ABTCP (Associação Brasileira Técnica de Celulose e Papel), deu-se através do curso ministrado pelo Dr. Celso Foelkel "As Biorrefinarias Integradas no Setor Brasileiro de Fabricação de Celulose e Papel de Eucalipto”, em setembro de 2012.

A pesquisa de campo foi conduzida prioritariamente no período de setembro a novembro de 2012, sendo realizada uma entrevista no início de 2013. De maneira similar aos workshops de construção do roadmap propostos pela metodologia de PHAAL (2001b), o presente estudo utilizou a pesquisa de campo como ferramenta para obtenção das mesmas informações que poderiam ser levantadas em seminários presenciais. Isto permitiu utilizar um meio através do qual os especialistas e formadores de opinião podem expressar individualmente seu ponto de vista para construir fluxo de tecnologia ao longo do tempo para a elaboração do roadmap. 
TABELA 9: Universo de entrevistas realizadas (elaboração própria).

\begin{tabular}{|c|c|c|c|c|}
\hline \# & Empresa & Categoria & Cargo do Respondente & obs \\
\hline 1 & Green Biologics & $\begin{array}{l}\text { Desenvolvedor } \\
\text { Biobutanol }\end{array}$ & $\begin{array}{l}\text { Gerente de } \\
\text { Desenvolvimento de } \\
\text { Mercado }\end{array}$ & Butyl Fuel \\
\hline 2 & Rhodia & $\begin{array}{l}\text { Desenvolvedor } \\
\text { Biobutanol }\end{array}$ & $\begin{array}{l}\text { Diretor Técnico de } \\
\text { Projeto }\end{array}$ & Cobalt Technologies \\
\hline 3 & Butamax & $\begin{array}{l}\text { Desenvolvedor } \\
\text { Biobutanol }\end{array}$ & Gerente de Tecnologia & DuPont / BP \\
\hline 4 & Braskem & $\begin{array}{l}\text { Especialista em } \\
\text { Roadmap }\end{array}$ & $\begin{array}{l}\text { Avaliação de } \\
\text { Tecnologias } \\
\text { Renováveis }\end{array}$ & $\begin{array}{l}\text { foco renováveis e } \\
\text { roadmaps }\end{array}$ \\
\hline 5 & Elekeiroz & $\begin{array}{l}\text { Usuário ou fabricante } \\
\text { de butanol }\end{array}$ & $\begin{array}{l}\text { Gerente de P\&D e } \\
\text { Inovação }\end{array}$ & produtor de butanol \\
\hline 6 & Dow & $\begin{array}{l}\text { Usuário ou fabricante } \\
\text { de butanol }\end{array}$ & Cientista Principal & $\begin{array}{l}\text { produtor e usuário de } \\
\text { butanol }\end{array}$ \\
\hline 7 & Oxiteno & $\begin{array}{l}\text { Usuário ou fabricante } \\
\text { de butanol }\end{array}$ & $\begin{array}{l}\text { Acessor Técnico da } \\
\text { Diretoria }\end{array}$ & $\begin{array}{l}\text { produtor e usuário de } \\
\text { butanol }\end{array}$ \\
\hline 8 & Usina São Martinho & $\begin{array}{l}\text { Usuário ou fabricante } \\
\text { de butanol }\end{array}$ & $\begin{array}{l}\text { consultor P\&D / } \\
\text { Inovação }\end{array}$ & $\begin{array}{l}\text { consultor / produtor } \\
\text { local Bioetanol }\end{array}$ \\
\hline 9 & Unicamp & $\begin{array}{l}\text { Inst Pesquisa, } \\
\text { Universida de ou } \\
\text { Associação }\end{array}$ & Prof. Eng. Quimica & $\begin{array}{l}\text { pesquisa butanol } \\
\text { (fermentação e } \\
\text { destilação) }\end{array}$ \\
\hline 10 & NIPE & $\begin{array}{l}\text { Inst Pesquisa, } \\
\text { Universidade ou } \\
\text { Associação }\end{array}$ & $\begin{array}{l}\text { Prof. Eng. Agrícola, } \\
\text { Nucleo Integração } \\
\text { Pesq. Energéticas }\end{array}$ & $\begin{array}{l}\text { estudos estratégicos e } \\
\text { gaseificação }\end{array}$ \\
\hline 11 & CTBE & $\begin{array}{l}\text { Inst Pesquisa, } \\
\text { Universidade ou } \\
\text { Associação }\end{array}$ & $\begin{array}{l}\text { Diretor Programa } \\
\text { Industrial }\end{array}$ & $\begin{array}{l}\text { hidrólise e } \\
\text { biorrefinaria }\end{array}$ \\
\hline 12 & ABTCP & $\begin{array}{l}\text { Inst Pesquisa, } \\
\text { Universidade ou } \\
\text { Associação }\end{array}$ & Consultor & $\begin{array}{l}\text { curso de } 16 \text { horas } \\
\text { sobre biorrefinarias }\end{array}$ \\
\hline
\end{tabular}




\section{Resultados e Discussão}

O presente capítulo traz a apresentação dos resultados obtidos nas entrevistas na fase de pesquisa de campo, e a discussão dos assuntos provenientes destas interações. O registro traz a reprodução das respostas de maneira agregada, sem correlação com os respondentes individualmente. As respostas são analisadas em três grandes blocos, correspondentes às perguntas elaboradas para entendimento sobre os mercados para biobutanol, os produtos e tecnologias. Quando aplicável, à frente de cada resposta aparecerá o código da pergunta correspondente.

6.1 - Resultados das Entrevistas - Mercados.

As entrevistas foram iniciadas pela etapa de mercado, com o objetivo de identificar as necessidades futuras que deverão ser satisfeitas pela oferta de biobutanol. As perguntas desta fase estão reproduzidas na FIGURA 17.

\begin{tabular}{|l|} 
Dimensão \\
Mercado \\
A1: Qual a oportunidade para biobutanol no mercado mundial? \\
A2: Qual o potencial para o biobutanol no mercado brasileiro? \\
A4: Qual o posicionamento de sua empresa no mercado mundial? \\
A6: Quals paises vão liderar a produção de biobutanol? \\
A7: Qual posicionamento do biobutanol frente ao bioetanol? \\
A9: Quais as barreiras à comercialização do biobutanol? \\
A10:Qual o posicionamento de custo frente a outros combustiveis \\
A11: Qual o patamar de custo para ampla comercialização? \\
A12: Quais os planos divulgados e públicos de comercialização? \\
A13: Prazos esperados para comercialização no Brasil? \\
A14: Outros aspectos relativos a mercado ainda não abordados. \\
\hline
\end{tabular}

FIGURA 17: Perguntas utilizadas na pesquisa de campo, relativas à dimensão mercado (elaboração própria). 
Encontram-se abaixo transcritas algumas respostas obtidas nesta fase. As respostas colaboram para o processo de aprendizado característico do roadmapping durante as interações e elaboração do mapa final.

A1: "O n-butanol é um novo produto para o mundo, que deverá ser aceito somente se chegar ao mesmo nível de preço que o produto obtido por rota sintética. Os consumidores não pagam um diferencial de preço por consumirem um produto de fonte renovável".

A1: "O mercado de combustíveis paga pouco. O biobutanol deve encontrar seu nicho em produtos químicos. O custo deve ser baixo, pois o selo "verde" não garante que consumidores pagarão mais pelo produto".

A1: "A comercialização do biobutanol dependerá, em primeiro lugar, do prazo requerido para a demonstração da sua viabilidade técnica e econômica, em escala comercial, de acordo com a tecnologia selecionada, dado que existem algumas tecnologias em desenvolvimento. De modo geral, não menos que cinco anos são requeridos para percorrer todas as etapas, desde o set-up do programa de $P \& D$, até a demonstração comercial da tecnologia correspondente".

A1: "Se o processo gerar menos $\mathrm{CO}_{2}$ é interessante. Do contrário é desperdício de carbono".

A1: "O butanol pode ser um aditivo interessante para gasolina, principalmente se tiver efeito anti-detonante. Também contribui para o aumento do nível de solventes oxigenados na gasolina, o que é um requisito".

A2: "O biobutanol enfrenta uma grande concorrência devido à grande variedade de opções de combustíveis já existentes e comerciais".

A2: "O Brasil já produziu butanol por diferentes rotas, hoje o processo oxo é o mais eficiente". 
A2: "O uso do butanol seria similar ao uso do etanol anidro como aditivo da gasolina. Poderia-se pensar em motores flex convertidos a "multifuel", em que pudessem usar também butanol com a garantia do fabricante".

A2: "O custo de produção é determinante. Sem competitividade não há "produto verde" que resista".

A2: "O biobutanol é uma boa escolha pelo menor custo do açúcar produzido no Brasil, e também por ser um produto de fonte renovável. O potencial do mercado brasileiro é pequeno, em torno de 50.000 toneladas. O país tem condições de se consolidar como base exportadora para o mundo. Atualmente no país existem apenas a Elekeiróz, com rota sintética, e a HC Sucroquímica, com pequena produção de rota biológica".

A2: "A produção de biobutanol no Brasil, se vier a se materializar, será em usinas novas (greenfield). É mínima a possibilidade de que os produtores consolidados do setor sucroalcooleiro decidam dedicar a totalidade, ou mesmo parte, de suas operações a biobutanol. Podemos, entretanto, assistir a materialização de algum projeto de pequenas proporções de biobutanol, como forma de adicionar mais um produto à "Lista de Produtos" (portfolio) da usina elou destilaria, desde que estes projetos possam ser melhor remunerados do que as atuais operações de produção de açúcar e álcool".

A3: "Hoje nossa organização emprega o processo ABE melhorado, produzindo n-butanol. Estamos focados no mercado de produtos químicos".

A3: "Estimular a conversão de usinas de etanol a butanol (isobutanol) com exportação e introdução conjunta no mercado norte-americano".

A3: "Desenvolvimento e comercialização de tecnologia". 
A3: "O mercado de intermediários químicos é nosso grande foco".

A4: "A produção não parece ser economicamente viável a partir da conversão de açúcar. Somente com o processo de hidrólise da celulose para liberação dos açúcares o produto deverá ser viável".

A4: "A atuação em diferentes países é através das seguintes modalidades: licenciamento de tecnologia, associação (joint venture), ou compra de usina para atuação própria. Existem modelos de atuação diferentes para cada país".

A5: "Os principais países que deverão ter destaque em biobutanol são aqueles com grande disponibilidade de biomassa. O Brasil é um candidato natural devido ao açúcar da cana".

A5: "Para que algum país se destaque, depende muito mais de aprovação de legislações específicas que disparem o gatilho das pesquisas".

A5: "A Índia também é um grande produtor de açúcar, com mais de 600 usinas".

A5: "A China tem base instalada já existente de biobutanol, com fortes subsídios à utilização de milho. Emprega atualmente tecnologia da Rússia".

A5: "Os Estados Unidos têm interesse no desenvolvimento de biobutanol como a alternativa mais viável para cumprir com as metas de biocombustíveis até 2022".

A6: "Os Estados Unidos deverão ter destaque se aprovarem a inclusão do biobutanol como biocombustível para receber subsídios. Assim poderão fazer através do milho. Porém há a discussão de concorrência com a cadeia alimentar".

A6: "A China apresenta produção atual".

A6: "Estados Unidos, Brasil, China". 
A7: "O Brasil já fez sua opção por etanol. O butanol não tem vez no país".

A7: "Uma grande vantagem do butanol seria se ele puder ser comprovado como aditivo em diesel".

A7: "Há um grande potencial do uso do butanol como aditivo ao diesel. O etanol não é solúvel em diesel".

A8: "Existem duas grandes barreiras hoje: preço da matéria prima e coordenar esforços para superar a escala necessária de produção para a introdução no mercado de combustíveis".

A8: "Os subsídios. Butanol não é classificado como biocombustível, portanto não recebe os mesmos subsídios que etanol ou biodiesel."

A8: "A comercialização como combustível exige larga escala, do contrário gera expectativa que não é atendida e leva ao descrédito como opção".

A8: "Em primeiro lugar não existe biobutanol. Em segundo lugar, se existisse, qual seria seu custo de produção e o seu respectivo preço de venda? Ninguém sabe e ninguém informa".

A8: "Falta de interesse das montadoras em aprovar o uso do produto. Se um consumidor usar butanol, pode perder a garantia do carro por uso de combustível não aprovado".

A8: "É necessário um Plano Nacional para desenvolvimento de butanol no Brasil. Não existe regulamentação ou incentivo. É necessário um estudo sério sobre a corrosividade, danos à saúde, emissões".

A9: "Regulamentação ANP".

A9: "As tecnologias de fermentação para biobutanol usam organismos geneticamente modificados (GMO). O Brasil tem regulamentação para uso de GMO, é preciso ver se estas 
tecnologias atendem. A usina também terá preocupação em usar um GMO em seu processo".

A9: "Há, sim, necessidade de estabelecer marcos regulatórios que viabilizem a utilização do biobutanol como combustível, desde que sua viabilidade técnico-econômica-ambiental esteja demonstrada. $O$ etanol (anidro e hidratado) no Brasil é um exemplo interessante de como estas necessidades foram atendidas".

A9: "No Brasil ainda não existe regulamentação para butanol como combustível. Faltam testes em metais, padrões de emissões, etc.".

A9: "Hoje todas as propostas existentes são estudos teóricos. Não existe um processo de biobutanol comercial. Se eu quiser comprar uma planta de biobutanol hoje não há tecnologia comercial comprovada".

A9: "Enquanto não houver reconhecimento pela regulamentação, a taxação impede a comercialização do produto".

A10: "O butanol tem um conteúdo energético maior que o etanol".

A10: "Atualmente o butanol sintético custa em torno de US\$2,00 por quilo. Para uso como combustível, o preço do biobutanol deveria ser menor que US\$1,00 por quilo".

A12: "Inicialmente focamos no mercado de produtos químicos com n-butanol. Em longo prazo, biocombustíveis."

A13: "O prazo para comercialização como combustível não é menor que 10 anos".

A13: "O n-butanol renovável deverá ser utilizado inicialmente como intermediário químico e solvente. Quando a produção atingir um patamar representativo, ele poderá ser utilizado como combustível. O mercado de combustíveis requer disponibilidade de volumes muito elevados". 
A13: "Os outros países deverão ter produção através de plantas de demonstração e escalas iniciais em até 05 anos. $O$ uso como combustível em larga escala não é esperado antes de 10 anos, pois os processos necessitam de uma curva de aprendizado e maturação da tecnologia".

A14: "Oportunidade de converter usinas que hoje se encontrem paradas".

A14: "O DME (di-metil-eter) é outro solvente de interesse".

A14: "Competir com o etanol de primeira geração não é viável. Precisamos desenvolver o processo de hidrólise”.

A14: "A hidrólise ainda não existe. Desde 2005 escuta-se que alguém chegou a grandes resultados, porém nada se concretiza".

A14: "O biobutanol só é uma opção se houver escassez de propeno para produção pela rota sintética”.

A14: "O uso do biobutanol como matéria prima para a indústria química está contingenciado pelo seu custo de produção (e seu respectivo preço de venda)".

As diferentes respostas indicam algumas linhas de análise. Existem dois isômeros que podem ser obtidos por fermentação: o isobutanol e o $\mathrm{n}$-butanol. As empresas interessadas no desenvolvimento de biobutanol no Brasil têm claramente um foco exportador. O mercado interno deverá ser suprido facilmente pelas produções iniciais de $n$-butanol. Neste caso, existe vantagem inicial para usinas produtoras de bioetanol que convertam parte ou a totalidade de sua produção a biobutanol. O n-butanol deverá ser vendido a preço de matéria prima química, e não a preço de combustível. Estima-se que o preço do n-butanol possa atingir uma rentabilidade muito superior à remuneração esperada para a venda de bioetanol ou biobutanol como combustível. Esta oportunidade já foi identificada por ao menos uma empresa no mercado, usuária de n-butanol para produção de éteres de glicol, que está fomentando a produção local a fim de obter matéria 
prima a preços mais baixos que os praticados no mercado atual. O excedente de produção será destinado à venda a outras empresas.

Embora ainda não tenham anunciado produção local de isobutanol, ao menos uma das empresas desenvolvedoras deste produto tem forte presença local. A Butamax (joint venture de BP e Dupont) possui um laboratório de desenvolvimento de processos em Paulínia-SP, e conta com o suporte de mais de 150 profissionais mundialmente.

Claramente a produção de biobutanol no Brasil inicialmente será destinada ao mercado químico e exportador. O uso do produto como biocombustível no Brasil não é esperado em um curto espaço de tempo. Existem potenciais para uso como combustível de aviação ou utilização como combustível automotivo. Porém atualmente não existe nenhum esforço para estudos oficiais e aprovação legal do uso do butanol como combustível automotivo no Brasil.

A FIGURA 18 exemplifica o crescimento esperado para a produção de biobutanol no mundo. Originalmente produzido pelo processo ABE tradicional, o biobutanol entrou em declínio a partir de 1950, embora tenha continuado a ser produzido comercialmente até 1980 e sempre tenha sido produzido em situações específicas para atender demandas locais. A rota petroquímica dominou a partir de então, até que o aumento do preço do petróleo no início da década de 90 renovou o interesse em rotas fermentativas.

Com o desenvolvimento de novos microorganismos, rotas fermentativas, tecnologia de fermentação e destilação, e disponibilidade de matéria prima, o processo biológico volta a ganhar importância. Inicialmente destinados ao mercado de solventes, os primeiros volumes produzidos serão destinados a um mercado potencial de US\$ 6 bilhões. Caso comprovem sua viabilidade, estes processos devem oferecer um elevado grau de concorrência à rota petroquímica, em especial se houver escassez de propeno no futuro. As novas reservas anunciadas de gás de xisto (shale gas) nos Estados Unidos são ricas em etano, porém contêm pouco ou nenhum propano a ser explorado comercialmente. 


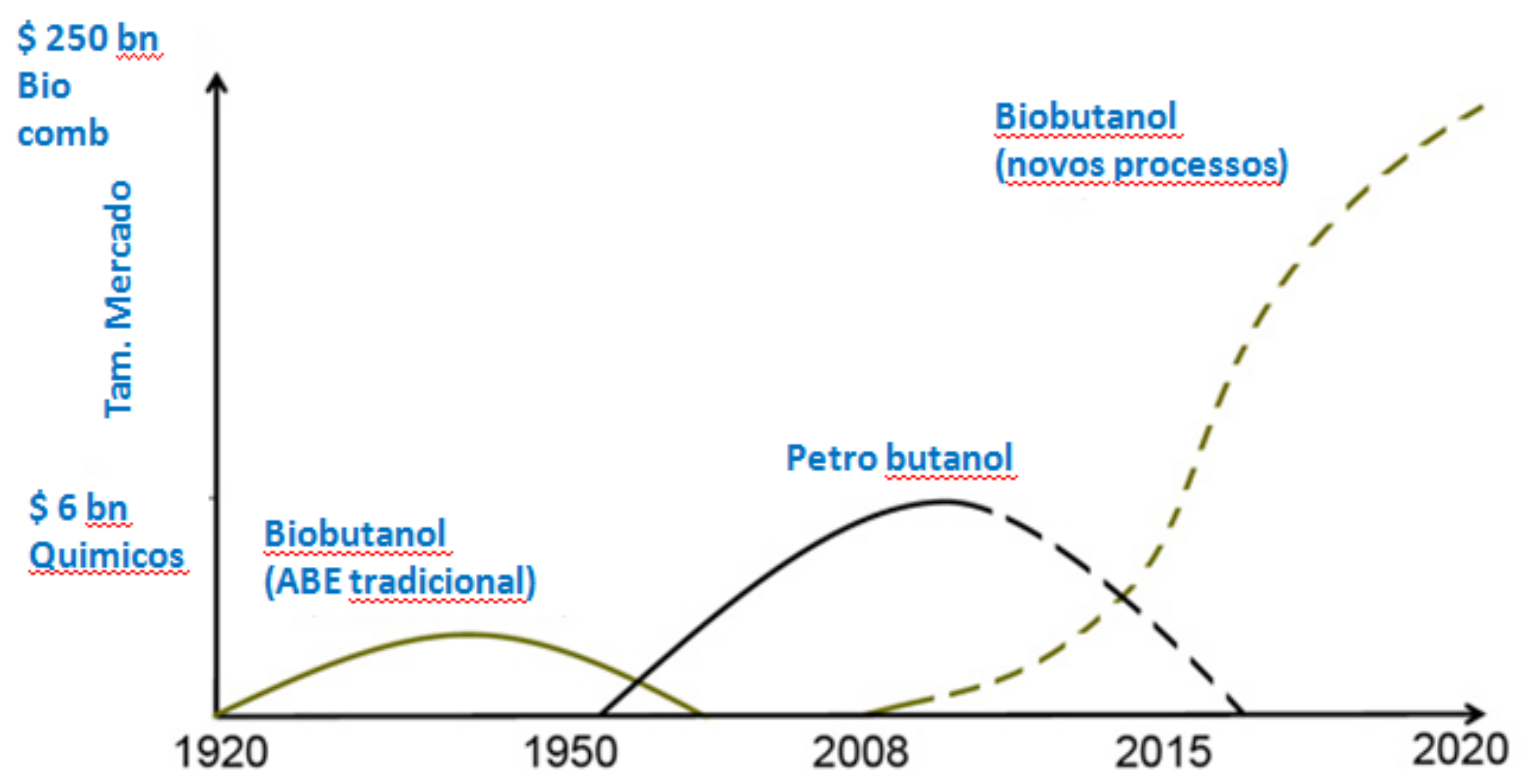

FIGURA 18: Perspectivas para a introdução de biobutanol no mercado mundial (adaptado de NEJAME, 2010)

O conceito de produto de origem renovável, ou rota "verde", segundo os entrevistados, agrega pouco à estratégia de comercialização do produto. Sem dúvida deverá ser utilizado como um apelo de marketing porém o fator mais importante para a comercialização é de que o preço final do biobutanol seja competitivo com o butanol sintético.

Acredita-se que a introdução do biobutanol como combustível comece com a adoção em nichos de mercado, gerando volumes iniciais que aumentarão gradativamente até justificar a sua introdução em larga escala. Neste sentido, seria viável o uso de biobutanol, por exemplo, em combustíveis para aeronaves, ou máquinas agrícolas.

A rota fermentativa deverá então ser intensamente explorada, de maneira a gerar volumes suficientes para suprir o mercado de biocombustíveis a partir de 2015 , com um mercado potencial global estimado em US $\$ 250$ bilhões.

No mercado americano, a estratégia das empresas tem sido claramente no sentido de realizar a conversão de usinas produtoras de bioetanol para o biobutanol. Da mesma forma, as empresas de biobutanol no Brasil têm oferecido às usinas a possibilidade de integrar a produção de biobutanol ao seu portfólio de produtos, seja integralmente ou como parte de sua produção, para diversificação 
da produção. Embora no Brasil seja mais difícil a conversão total de uma usina de etanol a butanol, devido à existência de mercado para etanol combustível, é possível que algumas usinas adicionem a produção de biobutanol a seu portfólio como uma forma de diversificar a grade produtiva e reduzir sua exposição à sazonalidade e oscilação de preços de açúcar e álcool. Com isto, é possível melhorar a remuneração e o resultado financeiro da usina.

A utilização de cana-de-açúcar como matéria prima na matriz nacional é uma clara vantagem em relação à matriz norte-americana, que utiliza o milho como matéria prima. $\mathrm{O}$ desenvolvimento dos processos de hidrólise da celulose podem aumentar a produtividade, seja pelo uso do bagaço de cana-de-açúcar ou de novas matérias primas até então não exploradas, como, por exemplo, a celulose proveniente de eucalipto.

O Brasil é uma nação líder na produção de celulose de fibra curta para produção de papel, devido à elevada produtividade do eucalipto brasileiro. Este fator poderá ser alavancado com o processo de hidrólise, para integração das plantas de polpa de celulose a biorrefinarias, utilizando resíduos florestais ou mesmo florestas plantadas e renováveis para destinação à fabricação de biocombustíveis.

Segundo os entrevistados, a adoção de butanol como combustível no Brasil somente seria viável se for uma operação rentável também para as empresas petroleiras que controlam a distribuição de gasolina. Assim, empresas como Petrobrás, Shell e BP poderiam influenciar a adoção de um marco regulatório para incorporação do butanol à matriz de biocombustíveis permitidos no país. Devido à sua escala, somente com um esforço coordenado e agenda comum seria possível a adoção de biobutanol no país.

Uma das oportunidades para o Brasil seria a pesquisa do biobutanol como possível componente de misturas com diesel. Hoje o bioetanol não é utilizado devido às suas limitações de solubilidade. O biobutanol poderia ser um combustível adequado para misturas com diesel petroquímico ou mesmo biodiesel, reduzindo assim a demanda nacional por diesel importado. 
A Agência Nacional do Petróleo (ANP), ainda não tem estudos oficiais sobre o butanol combustível no Brasil, o que é fundamental para a permissão de seu uso. Da mesma maneira, são desconhecidos estudos para avaliar o impacto ao meio ambiente de motores utilizando butanol.

6.2 - Resultados das Entrevistas - Produtos.

A etapa seguinte no roteiro de entrevistas cobriu os aspectos relativos a produtos. As perguntas desta fase estão reproduzidas na FIGURA 19.

\begin{tabular}{|l|} 
Dimensão \\
Produto \\
B1: Que produtos são desenvolvidos e comercializados? \\
\hline B2: Quais os principais diferenciais frente à gasolina? \\
B3: Quais os principais diferenciais frente ao etanol? \\
\hline B5: Quassificação da ordem de importância das propriedades. \\
\hline B6: Outros aspectos relativos a produto ainda não abordados. \\
\hline
\end{tabular}

FIGURA 19: Perguntas utilizadas na pesquisa de campo, relativas à dimensão produto (elaboração própria).

Encontram-se abaixo algumas respostas obtidas nesta fase. Respostas similares foram suprimidas deste registro.

B1: "Tanto isobutanol como $n$-butanol podem ser obtidos. $O$ processo ABE já era empregado desde a $2^{a}$ Guerra Mundial".

B1: "O processo gera "bio"acetona, que também deve ser comercializada para contribuir com a viabilidade comercial do processo".

B2: "O isobutanol deve ser vendido diretamente à refinaria para que seja adicionado à gasolina". 
B2: "O isobutanol tem octanagem superior ao $n$-butanol. O etanol tem apenas $70 \%$ do poder calorífico da gasolina. O butanol tem $90 \%$ do poder calorífico, sendo mais efetivo".

B3: "O butanol apresenta vantagens na partida a frio, sendo uma melhor opção que etanol para países frios".

B4: "A principal vantagem do biobutanol é a baixa higroscopicidade, seguida pelo maior poder calorífico frente ao etanol".

B4: "O etanol só pode ser misturado com gasolina. O butanol é solúvel em gasolina e diesel".

B5: "O uso de matérias primas alimentícias (amido, milho, beterraba), não é sustentável para produzir combustíveis".

B6: "O desenvolvimento dos processos de hidrólise é fundamental para aproveitamento de biomassa".

B6: "Existe oportunidade para butanol como aditivo do diesel. Neste aspecto, a solubilidade é muito importante".

O n-butanol é o principal isômero de interesse imediato no Brasil. Existe um consumo no mercado doméstico da ordem de 50.000 toneladas por ano, destinados ao uso como solvente ou intermediário químico principalmente para a fabricação de plastificantes. A produção atual de n-butanol no Brasil por via petroquímica atinge 20.000 toneladas anuais na Elekeiroz, único produtor nacional, utilizando o processo oxo. A Usina Paraíso fabrica desde 2006 o bio(n)butanol, com uma produção anual estimada em 2.000 toneladas. Desta maneira, a produção atual supre apenas 30 a 40\% da demanda. O restante do consumo é baseado em importações realizadas por empresas como Dow, Basf, Celanese e Eastman. $O$ Brasil, portanto, é um mercado importador neste momento.

É esperado que a demanda doméstica por n-butanol cresça para 150.000 toneladas em 2015. A produção inicial de n-butanol por rota fermentativa deverá ser direcionada ao suprimento das necessidades do produto como intermediário químico, como por exemplo a fabricação de acrilato de butila. A produção deste 
monômero deverá ser intensificada com a entrada em operação da fábrica de ácido acrílico da Basf em 2015. O ácido acrílico é matéria prima para o acrilato de butila, juntamente com o butanol.

As empresas que focam sua tecnologia na produção de isobutanol ainda não anunciaram planos de produção comercial no Brasil. Uma destas empresas possui uma sólida presença local para desenvolvimento de mercado, porém ainda sem produção anunciada. Ela trabalha atualmente com a possível conversão de usinas de etanol em sua totalidade ou em parte de sua produção para butanol.

6.3 - Resultados das Entrevistas - Tecnologias.

A parte final do questionário de entrevistas contempla as tecnologias. As perguntas desta fase estão reproduzidas na FIGURA 20.

\begin{tabular}{|l|} 
Dimensão \\
Tecnologia \\
C1: Quais as linhas centrais de desenvolvimento de sua empresa? \\
\hline C2: Quais as fontes mais propícias à produção de butanol no país? \\
C3: Quais os principais microorganismos para conversão? \\
\hline C5: Prazos de comercialização por tipo de microorganismo? \\
\hline C6: Prazos de comercialização por tipo de fermentação. \\
C7: Principais desenvolvimentos no processo de separação? \\
\hline C8: Prazos de comercialização por tipo processo de separação. \\
\hline C10: Principais desenvolvimentos para superar alguns gargalos. \\
\hline C11: Prazos esperados para comercialização de algumas técnicas? \\
\hline C12: Quais os recursos técnicos da empresa? \\
\hline C13: Qual o cenário de propriedade intelectual em biobutanol? \\
\hline C14: Outros aspectos relativos a tecnologia ainda não abordados. \\
\hline
\end{tabular}

FIGURA 20: Perguntas utilizadas na pesquisa de campo, relativas à dimensão tecnologias (elaboração própria). 
Encontram-se abaixo algumas respostas obtidas nesta fase. Respostas similares foram suprimidas deste registro:

C1: "Atuamos na microbiologia industrial, com novas rotas metabólicas, instrumentação, ferramentas de simulação e otimização, engenharia de reatores, colunas e recuperadores, estudo de redução do consumo de energia".

C2: "O processo derivado de açúcar de cana ou de amido de milho é caro. A hidrólise permitirá um acesso a fontes de carbono mais baratas".

C2: "O uso de uma determinada matéria prima ou outra dependerá de subsídios do governo".

C3: "As bactérias Clostridia tem mecanismo conhecido de conversão de pentoses".

C3: "Para isobutanol, é possível que sejam utilizadas variações de E.Coli".

C3: "O uso de organismos geneticamente modificados em uma usina que também produz açúcar, pode afetar negativamente a percepção do consumidor. Mesmo que a unidade de butanol seja tecnicamente isolada do etanol e açúcar, a percepção pode ser de possível contaminação do alimento".

C4: "A alteração genética (expansão genética) de levedura S.Cerevisae ainda não atingiu metas de aplicação comercial para produção de butanol".

C4: "A vantagem da fermentação $A B E$ é que as rotas de diversos tipos de Clostridia são conhecidas. Os demais desenvolvimentos com E.Coli não têm se demonstrado estáveis. Os desenvolvimentos com leveduras continuam, pois estas poderiam ser mais robustas para suportar variações no processo". 
C5: "Produzir butanol pode ser uma grande vantagem para a conversão de pentoses (xilose)".

C5: "Toda a produção de etanol hoje no Brasil é por processo batelada. Espera-se que processos produtivos para solventes similares, como butanol, sejam também por batelada".

C5: "As usinas precisarão aprender a trabalhar com ambiente estéril"

C5: "A necessidade de manter o reator estéril é um grande gargalo. É preciso usar temperatura, portanto empregado vapor, que custa caro. Os equipamentos devem ser de aço inoxidável grau sanitário, com paredes espessas, o que eleva significativamente o custo de uma nova instalação para butanol".

C6: "As pesquisas de processos utilizando leito imobilizado ainda são incipientes, apresentando baixa produtividade”.

C6: "Todos os processos são conhecidos, a adoção de um tipo de reator ou outro depende apenas de cálculos de engenharia e viabilidade econômica".

C6: "O processo contínuo é um grande desafio em rotas biológicas, pois leveduras e bactérias não são máquinas. Portanto, produzem rendimentos de maneira muito variável dependendo de nutrientes, clima, contaminantes. Sofrem mutações, fazem o que é preciso para sobreviver".

C6: "O processo em batelada com remoção do solvente por vácuo deve ser a rota a ser adotada nos projetos mais imediatos. O grande desafio ainda é o dimensionamento de grandes bombas para gerar vácuo em um grande fermentador, assim como o consumo de energia neste processo".

C6: "Hidrólise do bagaço de cana deve ser uma realidade entre 5 e 10 anos. Com mais adaptações, será possível hidrolisar outros materiais, inclusive madeira de eucalipto". 
C7: "A separação por membranas não atinge um nível muito elevado de pureza”.

C8: "Existe muita propaganda de start-ups, e pouco material fundamentado em ciência”.

C9: "O scale up de um processo biológico é muito mais desafiador que um processo químico convencional. A escala não é linear".

C9: "A rota mais viável atualmente ainda é a melhoria de bactérias do gênero Clostridia".

C9: "A utilização de outros organismos geneticamente modificados é mais eficiente para produzir, porém menos eficiente para conviver e utilizar".

C9: "Um dos principais gargalos no Brasil é a necessidade de assepsia dos reatores e sistemas para butanol. É necessário utilizar grande quantidade de vapor e por muito tempo para esterilizar 0 sistema, o que é muito caro".

C9: "Como será o reprocessamento ou inativação dos microorganismos geneticamente modificados do butanol? Isto é um problema. Para o etanol, utiliza-se leveduras, que ao final do processo podem até ser vendidas como ração animal”.

C9: “Uma grande oportunidade para o butanol é ser utilizado em futuros processos de segunda geração: com a hidrólise da celulose, as hexoses poderiam ser convertidas a etanol com leveduras convencionais, e as pentoses convertidas em butanol, pois bactérias Clostridia têm esta capacidade naturalmente".

C10: "É possível coordenar diversos processos paralelos em batelada, tornando o resultado da produção um fluxo contínuo".

C10: "O controle da esterilidade do substrato e dos equipamentos é um grande problema na usina. Hoje existe grande variabilidade e as 
leveduras são resistentes. No caso do butanol, o processo deve ser sanitário".

C10: "O controle de assepsia é o principal desafio para implementação, devido ao grande tamanho dos equipamentos".

C10: "O controle de assepsia do sistema é fundamental para a fermentação empregando Clostridia".

C11: "A gaseificação de biomassa é um processo interessante, porém precisa de altos volumes de matéria prima. Somente um pool de usinas poderia coordenar o suprimento constante de bio-óleo para uma refinaria".

C12: "Temos um cluster de desenvolvimento instalado no Brasil".

C13: "Falta uma política nacional para pesquisa de butanol".

C13: "Existe uma corrida para patentes de meios de separação do solvente, assim como organismos geneticamente modificados. Para Clostridia, não há concorrência".

C14: "A compatibilidade com diesel. O índice de cetano do butanol é bem favorável".

C14: "A usina de cana brasileira precisa mudar, e começar a pensar como uma biorrefinaria".

C14: "A oferta de gás de xisto (shale gas) a baixo custo deve postergar os planos para comercialização de fontes alternativas de energia".

C14: "É preciso ser mais científico e menos emocional. A rota microbiológica pode não ser a mais viável em longo prazo".

C14: "O Brasil deveria reavaliar seu modelo. Se o país produzisse somente álcool anidro, seria possível adicionar à gasolina nacional e exportar, por exemplo, para os Estados Unidos, suprindo grande parte das necessidades deles para o E10. No Brasil a indústria 
automobilística poderia voltar a fornecer motores afinadíssimos para uso com uma mistura específica de gasolina e etanol, eliminando os atuais motores flex que possuem baixo rendimento".

C14: "O mercado de combustíveis de aviação poderia empregar o butanol, mesmo que como intermediário para síntese de outros combustíveis. É um mercado com grande necessidade de redução de emissões, e que remunera muito bem pelo combustível".

C14: "A usina de cana hoje já gera três grandes valores: álcool, açúcar e eletricidade. O butanol poderia agregar a este conjunto, porém é necessário um plano nacional".

As empresas que desenvolvem tecnologia em biobutanol são prioritariamente empresas de biotecnologia, iniciadas tipicamente como spin off acadêmicos ou a partir de capital especulativo ou, como no caso da DuPont, empresas tradicionais em biotecnologia. Existe uma movimentação intensa no mercado para consolidação de empresas e aquisição de tecnologias.

As empresas DuPont e BP, desde 2005, anunciaram a criação da Butamax destinada exclusivamente à pesquisa e comercialização de biobutanol. $\mathrm{O}$ centro de pesquisas em Paulínia-SP integra a rede global de desenvolvimento da empresa, que inclui plantas de demonstração nos EUA. A empresa diz que é possível exportar 7,6 bilhões de litros de isobutanol do Brasil até 2020.

A Green Biologics associou-se à Butyl Fuel, combinando os seus conhecimentos em otimização de mais de 150 espécies de Clostridia aos conhecimentos de processo da Butyl Fuel no mercado norte-americano. As empresas diferenciam a tecnologia oferecida em cada país, adaptando-a às matérias primas e microorganismos mais adequados a cada região. A tecnologia oferecida pela Green Biologics classifica-se como um processo ABE melhorado.

A empresa Cobalt Technologies anunciou em agosto de 2012 seus planos para construir a primeira fábrica de biobutanol no Brasil em conjunto com a Rhodia até 2015. A capacidade de produção e os investimentos não foram 
revelados. Espera-se que esta unidade atue como uma usina de demonstração de processos.

Esta fábrica deverá ser baseada no bagaço de cana, portanto é estimado que utilize técnicas de hidrólise de celulose. Hoje este processo está em fase de demonstração em bancada e reatores piloto. Este deverá ser um dos grandes desafios do projeto, pois trata-se de um scale up de um processo bioquímico. Em processos químicos convencionais, em geral, o aumento de escala segue tendências lineares sendo ajustável de acordo com as operações unitárias envolvidas. Em um processo biológico, contudo, o aumento de escala não é tão previsível sendo, portanto, uma das incertezas do projeto.

Uma das barreiras apresentadas à produção de biobutanol no Brasil é o preço comparativo do açúcar, que compete pela mesma matéria prima para sua produção, assim como a para a produção de etanol. A produtividade atual dos processos com biobutanol é considerada baixa, não compensando o custo relativo do açúcar utilizado neste processo e que deixou de ser comercializado.

Uma das tendências neste sentido é novamente o desenvolvimento de processos de hidrólise da celulose, o que permitiria o uso de material lignocelulósico residual como folhas e o bagaço da cana, entre outras fontes possíveis. Hoje o bagaço é queimado nas usinas para conversão a energia elétrica. Seria possível utilizar a totalidade ou parte desta matéria prima tratada para futura fermentação. A hidrólise também poderia contornar o problema da sazonalidade da cana-de-açúcar no Brasil, que está disponível apenas durante 32 semanas por ano, tornando possível o uso de outras matérias primas de biomassa.

Segundo os entrevistados, as principais necessidades técnicas a serem desenvolvidas estão apontadas abaixo:

- Estudo de microorganismos capazes de fermentar açúcares de cinco (pentoses) ou seis carbonos (hexoses) provenientes de hidrólise de material lignocelulósico. 
- Redução do tempo de residência dos microorganismos para produção do biobutanol, permitindo aumento de produtividade e redução do tamanho das instalações.

- Aumento da seletividade para conversão de butanol, e menos etanol, acetona e outros subprodutos.

- Gestão de contaminações e assepsia do sistema, de maneira a manter as cepas puras para produção do solvente desejado.

- Obtenção de microorganismos com maior resistência ao butanol, de maneira a superar a barreira de $2 \%$ de concentração (para etanol este valor é ao redor de 12 a 13\%).

- Desenvolvimento de processos para remoção de solvente e purificação, contornando o problema da concentração de inibição, e reduzindo os custos com destilação de grandes quantidades de água.

A obtenção de butanol necessita de bactérias que devem atuar em um substrato (matéria prima) que foi previamente esterilizado, para evitar contaminações. Da mesma maneira, reator e demais equipamentos devem sofrer controle sanitário. Este fator foi citado pela maioria dos respondentes como de grande importância. A fermentação atual de etanol não necessita de esterilização. A adição desta etapa a um eventual processo de butanol, exige grande investimento em equipamentos, fabricados em aço inoxidável com revestimento sanitário. São necessárias elevadas temperaturas, de $120^{\circ} \mathrm{C}$ a $140^{\circ} \mathrm{C}$, por até 2 horas. Devido ao grande tamanho dos equipamentos em uma usina, o custo desta operação é muito elevado.

O uso e controle de organismos geneticamente modificados revela-se um desafio adicional para a usina. Com o decorrer da fermentação, estes organismos têm demonstrado degeneração e perda de produtividade. Em uma usina conjunta com etanol, uma eventual contaminação com leveduras do processo convencional poderia levar a uma rápida perda do organismo geneticamente modificado.

Os entrevistados consideram que os processos de separação envolvidos na produção de biobutanol são processos conhecidos na engenharia química, não sendo exclusivos à tecnologia deste solvente. Dependem, portanto, de adaptação 
para as condições e requisitos específicos do biobutanol como, por exemplo, membranas seletivas e de alta permeabilidade para isolamento deste solvente.

A produção comercial de novas fábricas de biobutanol é esperada para o período de 2 a 5 anos no Brasil. $O$ foco principal será no mercado interno de solvente e o mercado externo de combustíveis. O uso como combustível no Brasil, contudo, não é esperado dentro de um período de 10 anos.

Neste ambiente altamente competitivo, os participantes disputam também o posicionamento em termos de propriedade intelectual. As empresas envolvidas têm uma sólida produção científica e de patentes, sendo que em alguns casos existe intensa disputa pelas descobertas (GEVO, 2012).

No campo de incentivo à pesquisa, uma iniciativa conjunta do BNDES e da FINEP criou o programa PAISS - Plano Conjunto de Apoio à Inovação Tecnológica Industrial dos Setores Sucroenergético e Sucroquímico. O programa foi criado especificamente para o subsídio da pesquisa do etanol celulósico, aumentando a produtividade ao permitir a hidrólise do bagaço e da palha de cana-de-açúcar. Empresas de biobutanol tem se beneficiado dos financiamentos da linha 02. O programa compreende três linhas principais de pesquisa (FINEP 2012):

1) Bioetanol de Segunda Geração;

2) Novos produtos de cana-de-açúcar;

3) Gaseificação: Tecnologias, equipamentos, processos e catalisadores.

Alguns centros de excelência brasileiros em etanol também têm desenvolvido estudos em butanol. O Centro de Tecnologia Canavieira (CTC) e o Laboratório Nacional de Ciência e Tecnologia do Bioetanol (CTBE) estudam alternativas para o processo de butanol, este último com destaque para simulações de integração de processos através de programas de biorrefinarias virtuais (MARIANO, 2013). Na Unicamp, a Faculdade de Engenharia Química estuda microorganismos mais produtivos e métodos de remoção do solvente do meio fermentativo. Em outra linha de pesquisa, a Faculdade de Engenharia Química, em conjunto com a Faculdade de Engenharia Agrícola estuda métodos de termo conversão de biomassa. 
A FIGURA 21 traz uma análise SWOT para a produção de biobutanol no Brasil, ou seja, pontos fortes, deficiências, oportunidades e ameaças (strenghts, weaknesses, opportunities and threats), resumindo as observações efetuadas a partir dos resultados das entrevistas.

\begin{tabular}{|c|c|}
\hline $\begin{array}{l}\text { - Disponibilidade de biomassa a baixo custo } \\
\text { - Complementar a produção de etanol de } \\
\text { primeira geração } \\
\text { - Possibilidade de venda inicial de } \\
\text { n-butanol para solventes e químicos } \\
\text { - Integração à matriz energética dos países, } \\
\text { como biocombustível } \\
\text { - Compatível com motores e sistemas de } \\
\text { distribuição de gasolina. }\end{array}$ & $\begin{array}{l}\text {-Processo ABE tradicional não é econômico } \\
\text {-Necessidade de ambiente estéril. } \\
\text {-Processos alternativos apenas em fase de } \\
\text { demonstração. } \\
\text {-Microorganismos ainda apresentam baixa } \\
\text { produtividade e alta sensibilidade } \\
\text { ao butanol } \\
\text { - Destilação extrativa em desenvolvimento } \\
\text { e foco de intensa disputa de patentes. }\end{array}$ \\
\hline Forças & Fraquezas W \\
\hline $\begin{array}{l}\text { O Oportunidades } \\
\text {-Desenvolvimento de hidrólise de celulose, } \\
\text { em especial bagaço e palha de cana. } \\
\text {-Produção de biobutanol a partir de } \\
\text { hemiceluloses (pentoses). } \\
\text {-Estudo como aditivo para diesel. } \\
\text { - Influenciar os marcos regulatórios dos } \\
\text { países que necessitam de biocombustiveis. } \\
\text {-Criação de base exportadora a partir do } \\
\text { Brasil. }\end{array}$ & $\begin{array}{l}\text { Ameaças } \\
\text { - Presença de GMO pode prejudicar a } \\
\text { imagem do produto, em especial se } \\
\text { associado a usinas produtoras de } \\
\text { alimento (açúcar). } \\
\text {-Viabilização de rotas termoquímicas para } \\
\text { uso de biomassa a custo competitivo }\end{array}$ \\
\hline
\end{tabular}

FIGURA 21: Análise SWOT para produção de biobutanol no Brasil (elaboração própria). 


\section{Construção do Technology Roadmap para Biobutanol no Brasil}

O roadmap foi elaborado continuamente no decorrer da pesquisa bibliográfica e as entrevistas, sendo ajustado conforme novas informações ou inter-relação entre as informações tornava-se disponível. A FIGURA 22 ilustra a arquitetura e as informações disponibilizadas no roadmap gerado para este trabalho. Foram utilizadas as recomendações de PHAAL (2001a e 2001b) para a construção do T-Plan, disponíveis em português no trabalho de OLIVEIRA (2012).

A arquitetura utilizada estabelece, para cada dimensão (mercado, produto, tecnologias), quais são os direcionadores e o período de tempo em estudo. Em seguida, são dispostos eventos e qual período de tempo estimado para que ocorram.

Technology Roadmap para Biobutanol no Brasil - 2013

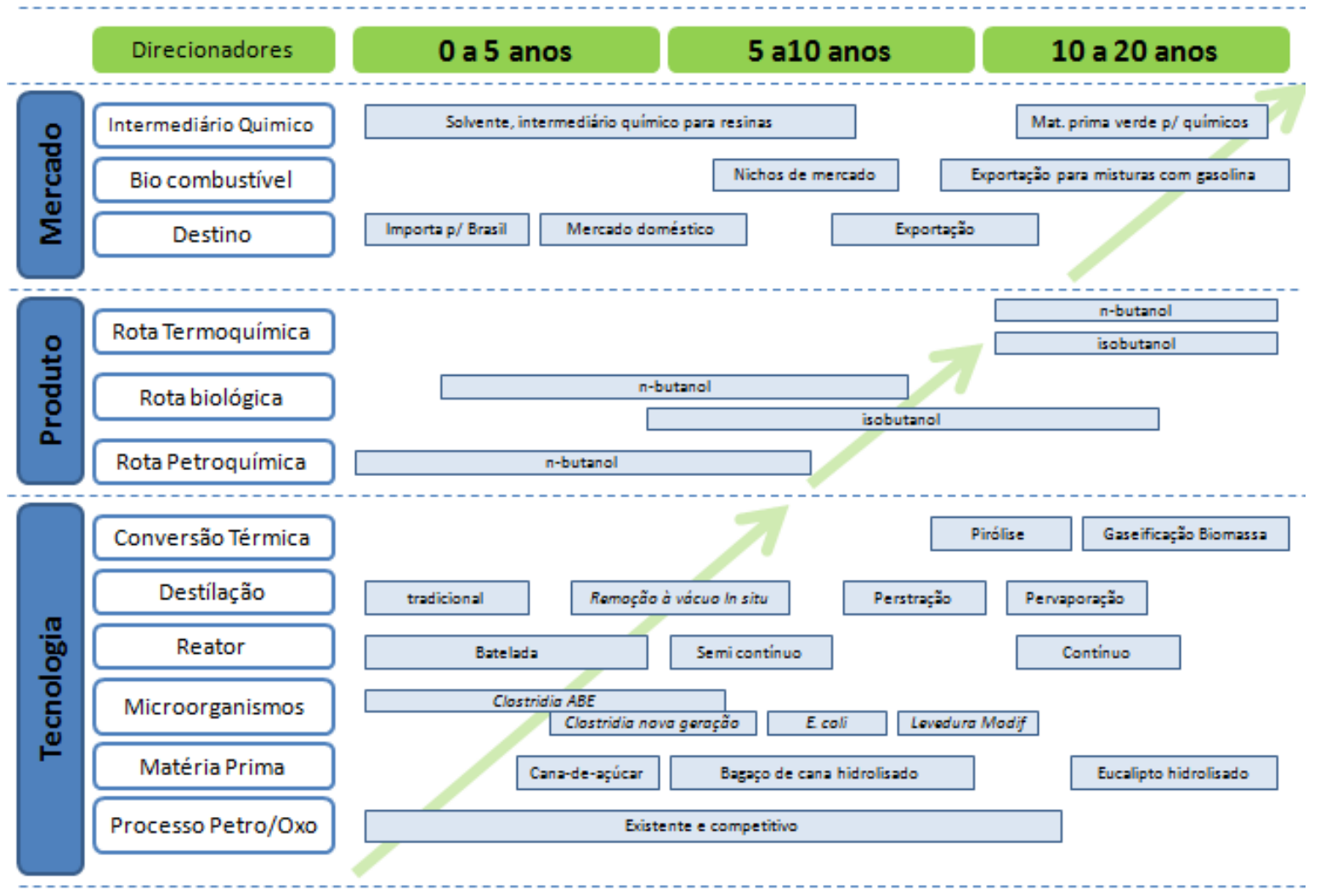

FIGURA 22: Technology Roadmap para Biobutanol no Brasil (elaboração própria)

Cada uma das dimensões é descrita isoladamente para melhor análise. $\mathrm{Na}$ FIGURA 23 está a dimensão mercado. Neste aspecto, o estudo indicou que no direcionador "destino das vendas" o Brasil encontra-se hoje como importador de produto, porém deve converter-se em autossuficiente para suprir o mercado 
doméstico e em um prazo de 5 a 10 anos deve tornar-se exportador. Os principais usos atuais são como intermediário químico e solvente. $O$ uso em nichos de mercado, por exemplo aplicações específicas de biocombustíveis, deve ser possível entre 5 a 10 anos, sendo esperado um aumento de disponibilidade até que se atinja maturidade para suprir o mercado de combustíveis em um grande mercado como o dos Estados Unidos. Neste ponto, os preços do produto devem tornar-se competitivos para permitir o uso do butanol também como matéria prima (feedstock) para produção de insumos como butadieno e outros. O eventual aumento de preços ou escassez de propeno e buteno podem acelerar estes prazos.

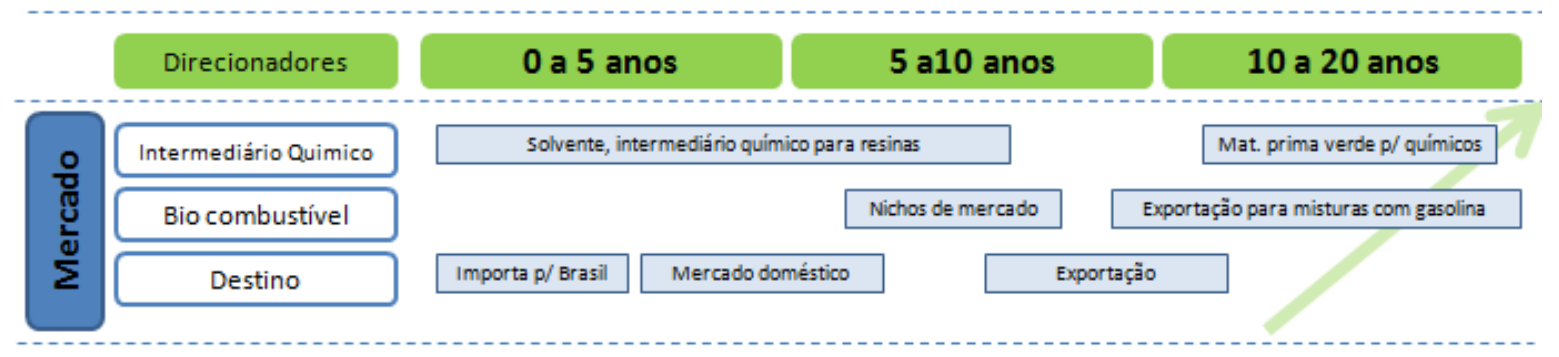

FIGURA 23: Visualização detalhada do Technology Roadmap na dimensão de mercado (elaboração própria)

Para cada uma das necessidades identificadas anteriormente, o butanol poderá ser suprido na forma de um de seus isômeros, n-butanol ou isobutanol, conforme FIGURA 24.

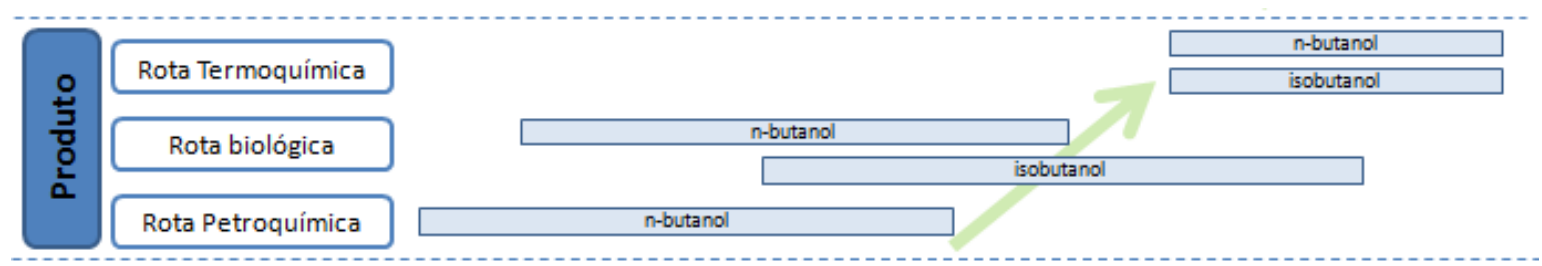

FIGURA 24: Visualização detalhada do Technology Roadmap no aspecto de Produtos (elaboração própria)

Entre as rotas principais possíveis, temos:

- a atual rota de síntese química, 
- a rota fermentativa em desenvolvimento e que poderá estar em escala comercial entre 5 a 10 anos, e

- a rota de termo conversão que ainda encontra-se em estágio inicial de desenvolvimento e depende de aperfeiçoamento para que se torne viável no futuro.

Na FIGURA 25 é possível a visualização de quais tecnologias entregarão os produtos necessários. Na rota atual existente, o processo "oxo" é competitivo e deve continuar a ser utilizado. Em termos de matéria prima, as plantas de demonstração em construção para biobutanol devem usar inicialmente açúcar de cana, e em seguida material proveniente de hidrólise de celulose. Uma vez que os processos de hidrólise estejam estabelecidos no futuro, será possível tratar outras fontes de biomassa como, por exemplo, o eucalipto. Os microorganismos para uso imediato continuam sendo as variações de Clostridium acetobutylicum e Clostridium beijeirinckii. A evolução deste processo inicial considera as mutações destes microorganismos. Processos envolvendo organismos geneticamente modificados podem envolver E.Coli e leveduras.

Os reatores, em curto prazo, devem continuar a empregar processos em batelada. A adoção de sistema de retirada de solventes a vácuo ou arraste de vapor é uma necessidade, sendo que no futuro poderão existir membranas mais seletivas e com baixa saturação. A rota de conversão térmica ainda encontra-se em estágio de desenvolvimento, porém é altamente desejável pela possibilidade de converter grandes volumes de biomassa. Este deverá ser um processo a ser adotado mais adiante para obtenção de butanol.

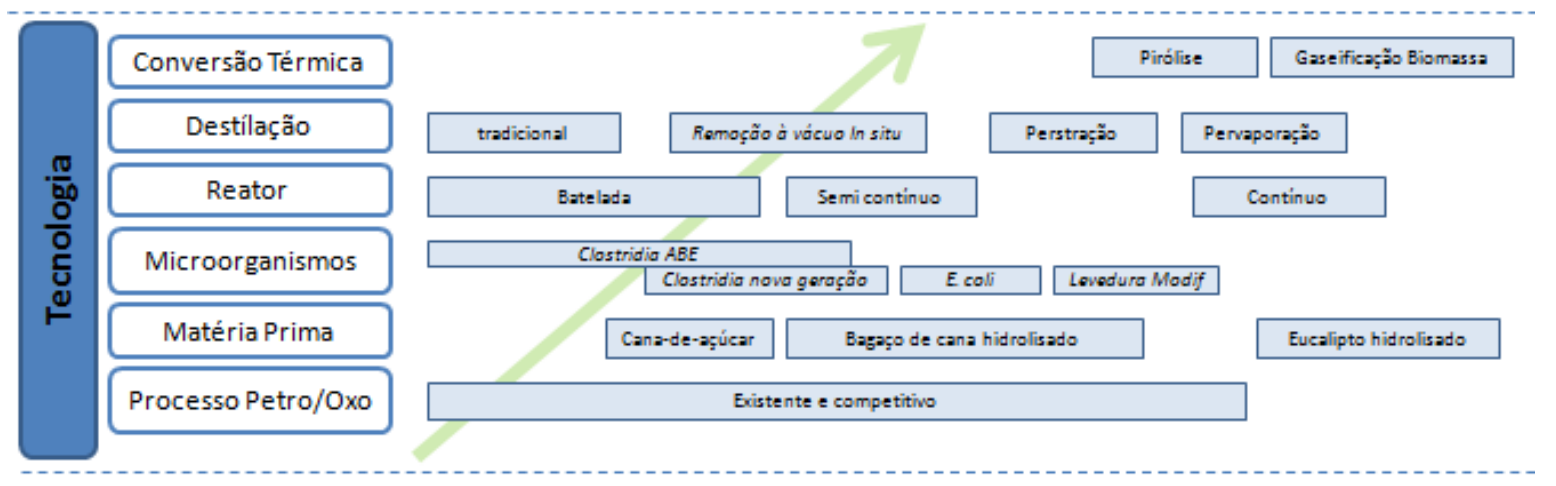

FIGURA 25: Visualização detalhada do Technology Roadmap no aspecto de Tecnologias (elaboração própria) 


\section{Conclusões e Futuras Direções de Pesquisa}

O uso da técnica de roadmapping demonstrou ser uma ferramenta adequada para aquisição, organização e análise de dados, gerando conhecimento durante o processo. O envolvimento e coleta de opiniões de especialistas é fundamental para validação das informações e análises coletadas. O roadmap final proporciona uma visão geral da situação atual de um tema, e a evolução das tecnologias para suprir necessidades futuras de produtos a mercados específicos. O roadmap não é um documento estático, devendo receber atualizações ao longo do tempo, incluindo novas informações para corrigir a sua rota.

De acordo com as informações adquiridas no decorrer do processo de revisão bibliográfica, condução de entrevistas com especialistas e elaboração do mapa final, o biobutanol apresenta potencial para uso como um biocombustível, complementar aos atuais biocombustíveis em uso como bioetanol e biodiesel.

O mercado potencial para biobutanol, contudo, ainda sofre incertezas. Embora suas propriedades físicas e de combustão demonstrem seu bom desempenho nos motores, o produto não é regulamentado como biocombustível. Este fato não permite que o produto receba incentivos e subsídios disponíveis a outros biocombustíveis.

O biobutanol pode ser obtido atualmente por processos já conhecidos, como a fermentação $A B E$. Este processo, contudo, tem baixa eficiência devido à baixa seletividade dos microorganismos, à toxicidade do butanol mesmo em baixas concentrações, e aos grandes volumes de água envolvidos o processo, o que demanda gastos com energia para a sua remoção.

Para que a produção torne-se mais eficiente, as pesquisas orientam-se no sentido de modificações genéticas de bactérias e leveduras. Contudo, estas rotas demonstram que os microorganismos ainda são sensíveis a mutações, contaminações e degeneração. $O$ uso de organismos geneticamente modificados também é uma fonte de preocupação para as usinas, necessitando de estudos específicos que regulamentem o seu uso. Os processos fermentativos para biobutanol exigem que todo o sistema produtivo tenha condições sanitárias e a 
operação de assepsia é demorada e custosa devido ao custo de capital necessário para estas instalações, assim como os gastos com utilidades para conduzir a operação.

Uma das linhas de pesquisa para aumentar a eficiência do processo e contornar o problema de toxicidade do butanol aos microorganismos, é a remoção contínua de solvente do meio fermentativio. Os processos ainda encontram-se em fase de pesquisa e demonstração, porém os mais divulgados são remoção à vácuo, remoção com solventes e remoção com arraste de gás.

A fabricação de biobutanol pode constituir-se uma excelente oportunidade para usinas nacionais de bioetanol diversificarem sua produção. Atualmente elas já contam com a flexibilidade de produzir açúcar e álcool e poderiam também agregar a opção de produzir butanol. No futuro, com o desenvolvimento de processos de hidrólise, poderiam ter a flexibilidade de decidir também entre utilizar o bagaço para produção de energia elétrica ou para produzir álcoois de segunda geração.

Os processos de convesão térmica para produção de combustíveis, entre eles o butanol, demonstram serem promissores, pois têm a possibilidade de converter totalmente a biomassa, gerando melhor aproveitamento do conteúdo de carbono. Também poderiam evitar as oscilações de um processo biológico. Contudo, as pequisas encontram-se ainda em fase inicial, sendo que estes processos devem ganhar importância no futuro.

O desenvolvimento de processos de hidrólise de celulose pode gerar potencial de uso integral da biomassa. O biobutanol seria uma importante complementariedade para a produção de bioetanol. As leveduras do processo de etanol converteriam as hexoxes, e as bactérias do processo de butanol converteriam as pentoses. Este processo contudo não é sinérgico e deve ocorrer em vasos separados, também envolvendo a já mencionada assepsia para produção de butanol.

Não somente o setor sucro-alcooleiro, mas também o setor de celulose e papel pode beneficiar-se da produção de biobutanol. Neste sentido é necessário fomentar estudos para hidrólise de eucalipto e termo-conversão de biomassa em 
biorrefinarias integradas. Atualmente, as empresas produtoras de celulose poderiam já beneficiar-se da produção de butanol através da recuperação de pentoses dos resíduos de processos, como o licor negro.

O Brasil deve converter-se de país importador a país exportador de $\mathrm{n}$ butanol com a adoção dos processos fermentativos. A venda incial será para o mercado doméstico de produtos químicos, seguido pela oferta para o mercado de produtos químicos de exportação e uso em nichos de mercado como biocombustível. Em uma fase posterior, poderá ser disponibilizado o produto para exportação como biocombustível. Para adoção como biocombustivel, são necessárias largas escalas, por isto o esforço concatenado de conversão conjunta. Marcos regulatórios também são necessários.

Principais Conclusões:

- Biobutanol é um biocombustível com promissor potencial de mercado, devendo ser desenvolvido em maior intensidade.

- As principais barreiras atuais ao desenvolvimento de biobutanol são a) inibição da fermentação devido ao efeito tóxico de butanol e acetona aos microorganismos, b) baixa concentração de butanol no meio fermentativo, c) obtenção de subprodutos, não necessariamente ligados à cadeia de valor do butanol, d) custo de instalações e operação de processos envolvendo condições sanitárias.

- A velocidade de adoção do biobutanol no futuro dependerá basicamente de dois fatores: o custo de produção do biobutanol a partir de biomassa, e o custo relativo do petróleo e de novas fontes de energia, como o gás de xisto (shale gas).

São condições que permitiriam o maior desenvolvimento de biobutanol:

- Microorganismos estáveis e produtivos para cada tipo de matéria prima.

- Matéria prima a preço baixo e altos volumes.

- Reator com remoção contínua de solvente ou produção contínua / semicontínua. 
- Minimizar subprodutos através de engenharia genética modificando as rotas fermentativas.

- Destilação com uso eficiente de energia, seja com vácuo, arraste com fluxo de gases, ou extração com solventes.

- Marcos regulatórios e apoio das montadoras de veículos.

Limitações da Pesquisa:

- A pesquisa envolveu principalmente uma pesquisa qualitativa. $O$ trabalho prévio de preparação e pesquisa bibliográfica foi importante para a condução das entrevistas. Porém as informações coletadas anteriormente influenciaram a análise das respostas da pesquisa.

- O processo de roadmapping indica direções propostas de desenvolvimento. Contudo, muitas das rotas e processos descritos são apenas teóricos, e não encontram-se em fase de maturação comercial.

- Houve participação de respondentes de diferentes áreas de atuação, portanto haveria necessidade de uma maior segmentação para análise das respostas.

Recomendações para pesquisas futuras:

- Coordenção de um plano nacional para uso de biobutanol em conjunto com bioetanol.

- Análise de ciclo de vida (LCA) para o biobutanol considerando a cana-de-açúcar como matéria prima.

- Utilização de resíduos do processo de fabricação de papel e celulose para obtenção de biobutanol.

- Intensificação dos estudos em rotas termoquímicas e gaseificação.

- Uso de pentoses para produção de butanol.

- Butanol como matéria prima para outros produtos químicos, atualmente derivados de propileno ou butileno. 
- Estudo do uso como aditivo para diesel. Isto permitiria misturas de butanol com diesel ou biodiesel, com potencial de reduzir as crescentes importações brasileiras de diesel, além de reduzir emissões. 


\section{Referências Bibliográficas}

ABE, H.; ASHIKI, T.; SUZUKI, A.; JINNO, F.; SAKUMA, H., Integrating business modeling and roadmapping methods - The Innovation Support Technology (IST) approach, Technological Forecasting and Social Change, 76, p. 80-90, 2009.

ADEME - The French Agency for Environment and Energy Management, Roadmap for Second-Generation Biofuels, Julho 2009.

AIC - Australian Institute of Commerce, Enabling Technologies Roadmap for the Department of Innovation, Industry, Science and Research, Nov. 2011.

AF\&PA - American Forest \& Paper Association, Forest Products Industry Technology Roadmap, Abril 2010.

ALBRIGHT, R.E.; A Roadmpapping Perspective: Science-Driven Technologies, Global Advanced Technologies Innovation Consortium, Zurique, disponível em www.albrightstrategy.com, acessado em 18Mai2012, Sep 2002 (a).

ALBRIGHT, R.E; What can past technology forecasts tell us about the future? Technological Forecasting and Social Change, 69, p. 443-464, 2002 (b).

ALBRIGHT, R.E.; KAPPEL, T.A.; Technology roadmapping: roadmapping the corporation. Research Technology Management, v. 46, n2, p31-40, 2003.

ARGONNE NATIONAL LABORATORY, Life-cycle assessment of cornbased butanol as a potential transportation fuel, ANL/ESD 07-10, 2010.

AMER, M; DAIM, T., Applications of Technology Roadmaps for Renewable Energy Sector, Technological Forecasting and Social Change, 77, (8), p. 1355-1370, 2010.

ANP - Agência Nacional do Petróleo, Biocombustíveis, disponível em www.anp.gov.br, acessado em 15Fev2013.

BLAIR, A.J., Working toward producing sustainable biodiesel in the Pacific Northwest: Analysis and implementation using the T-plan technology roadmapping approach, Portland International Conference on Management of Engineering Technology - PICMET, 2009.

BERGELT, K.; Charting the future: Motorola's approach to technology planning, Report of the $6^{\text {th }}$ Annual Cambridge Technology Management Symposium, 2010, Cambridge, 13-14 ${ }^{\text {th }}$ Julho, 10-11.

BIOMASS TECHNICAL ADVISORY COMMITTEE, Vision for Bioenergy \& Biobased Products in the United States, October 2002. 
BOHLMANN, G.; BRAY, R., Biobutanol, Report n. 264, Process Economic Program, SRI Consulting, Dezembro 2008.

BOHLMANN, G., Biobutanol, Process Economic Program, review 2007-1, SRI Consulting, Maio 2007.

BORSCHIVER, S., Analisando a Dinâmica do Mercado de Biocombustíveis, 7th Biodiesel Congress, 27 a 29 de Julho de 2011

BP, Energy Outlook 2030, publicado por British Petroleum, Londres, Janeiro 2012.

BRASIL, Balanço Energético Nacional 2011, ano base 2010, Ministério das Minas e Energia, 2011.

BUTALCO, Competence for Second Generation Biofuels Based on Lignocellulose, disponível em www.butalco.com, acessado em 01 Out2012.

CANADA, Innovation Roadmap on Bio-based Feedstocks, Fuels, and Industrial Products, Communications and Marketing Branch, Industry Canada, Otawa, 2005.

CARMANN, T.; Biobutanol: Profile of an advanced biofuel and its path to market, International Sugar Journal, 2011, Vol 113: 940100.

CARVALHO, M.M.; FLEURY, A.; LOPES, A.P.; An Overview of the literature on technology roadmapping (TRM): Contributions and trends, Technological Forecasting and Social Change, disponível online em 01Fev2013, disponível em http://dx.doi.org/10.1016/j.techfore.2012.11.008, acessado em 13Mar2013.

CASCONE, R.N., Biobutanol: A Replacement for Bioethanol?, SBE Special Section I- Biofuels, Society of Biological Engineering, pp. 1-9, 2009

CATHAY, disponivel em www.cathaybiotech.com, acessado em 12 Set2012.

CENBIO - $\quad$ Centro Nacional de Referência em Biomassa, disponível em http://cenbio.iee.usp.br, acessado em 15Jul2012.

CGEE - Centro de Gestão e Estudos Estratégicos, Roadmap tecnológico para produção, uso lipo e eficiente de carvão mineral nacional: 2012 a 2035, Série documentos técnicos, n. 14, Novembro 2012 a.

CGEE - Centro de Gestão e Estudos Estratégicos, Sustainability of sugarcane bioenergy, $2012 \mathrm{~b}$.

CGEE - Centro de Gestão e Estudos Estratégicos, Química Verde no Brasil: 2010-2030, 2010a. 
CGEE - Centro de Gestão e Estudos Estratégicos, Biocombustíveis aeronáuticos: progressos e desafios, Série documentos técnicos, n. 10, Novembro 2010b

CGEE - Centro de Gestão e Estudos Estratégicos. Bioetanol combustível, uma oportunidade para o Brasil, 2009.

CHEN, Y., Energy Science \& Technology in China: A Roadmap to 2050, Chinese Academy of Sciences, Springer, Beijing, 2010.

CHEN, C., POSNeR, A., FAWCETT, A., RAVIV, T., Butanol by two stage fermentation, Senior Design Reports, Department of Chemical and Biomolecular Engineering, University of Pennsylvania, 2009.

CHERUBINI, F., STROMMAN, A.H., Principles of Biorefinning, Biofuels: Alternative Feedstocks and Conversion Processes, Elsevier, 2011.

CHIAO, J.; SUN, Z.; History of the Acetone-Butanol-Ethanol Fermentation Industry in China: Development of Continuous Production Technology, $\boldsymbol{J}$ Mol Microbiol Biotechnol; 13:12-14, 2007.

CONTAG, P.R; NREL 21 ${ }^{\text {st }}$ Industry Growth Forum, Setembro 2008.

COOPER, R.G., Perspective: The Innovation Dilemma: How to Innovate when the Market is Mature, $\boldsymbol{J}$ Prod Innov Manag, 28 (S1), 2-27, 2011.

CORTEZ, L.A.B; Bioetanol de Cana-de-Açúcar P\&D para Produtividade e Sustentabilidade, Editora Edgard Blücher, São Paulo, p. 861-896, 2010.

CORTEZ, L.A.B., JORDAN, R.A., MESA-PÉREZ, J.M., ROCHA, J.D.; Roadmap tecnológico da termoconversão de biomassa para a tecnologia BTL (Biomass to Liquid), Workshop sobre Roadmaps Tecnológicos, UNICAMP, 11 de Setembro de 2009.

COSNER, R.R., et al. Integrating roadmapping into technical planning, Research and Technology Management, Vol. 50, n6, p. 52-58, Nov. 2007.

COUTINHO, P.; BOMTEMPO, J.V.; Uso de Roadmaps Tecnológicos para Favorecer o Ambiente de Inovação: Uma Proposta em Matérias Primas Renováveis, Anais do XIII Simpósio de Administração da Produção, Logística e Operações Internacionais (SIMPOI), Fundação Getúlio Vargas, Escola de Administração de Empresas de São Paulo, 2010.

COUTINHO, P.; BOMTEMPO, J.V., Roadmap Tecnológico em Matérias Primas Renováveis: Uma Base para Construção de Políticas e Estratégias no Brasil., Quim. Nova, Vol. 34, n. 5, 910-916, 2011.

COUTINHO, P.; Estratégia Tecnológica e Gestão da Inovação: Uma Estrutura Analítica Voltada para os Administradores de Empresas, Tese 
(Doutorado), Universidade Federal do Rio de Janeiro UFRJ, Escola de Química EQ, 2004.

CTM - Centre for Technology Management, University of Cambridge, disponível em www.ifm.eng.cam.ac.uk/ctm, acessado em 15Jul2012.

DAIM, T.U.; AMER, M.; BRENDEN, R.; Technology Roadmapping for wind energy: case of Pacific Northwest, Journal of Cleaner Production, 20, p. 2737, 2012.

DIDIO, R.J., Uma Nova Metodologia para Planejamento Estratégico Utilizando Mapas Tecnológicos e Detecção de Frentes Emergentes de Pesquisa Aplicada à Radiofarmácia, Tese (Doutorado), Instituto de Pesquisas Energéticas, IPEN, 2011.

DOE - US Department of Energy, Alternative Fuels Data Center, disponível em www.afdc.energy.gov/vehicles/flexible fuel emissions.html, acessado em 15Fev2013.

DOE - US Department of Energy, National Algal Biofuels Technology Roadmap, Maio 2010.

DOE - US Department of Energy, Breaking the Biological Barriers to Cellulosic Ethanol: A joint research agenda, DOE/SC-0095, 2006.

DRUMMOND, P.H.F., O Planejamento Tecnológico de Uma Empresa de Base Tecnológica de Origem Acadêmica por Intermédio dos Métodos Technology Roadmapping (TRM), Technology Stage Gate (TSG) e Processo de Desenvolvimento de Produtos (PDP) Tradicional, Dissertação (Mestrado), Universidade Federal de Minas Gerais, Departamento de Engenharia de Produção, 2005.

DURRE, P., Fermentative production of butanol - the academic perspective, Current Opinion in Biotechnology, vol. 22, pp. 331-336, 2011.

ELSEVIER, Science Direct, disponível em www.sciencedirect.com, acessado em 10 Abr2013.

ELY, R.N., Avaliação Prospectiva das Rotas de Bio-Refinaria no Brasil, a Partir do Bagaço de Cana-de-Açúcar como Matéria Prima Básica, Dissertação (Mestrado), Universidade Federal do Rio de Janeiro, 2009.

EPA - United States Environmental Protection Agency, Renewable Fuel Standards Program (RFS2) Regulatory Impact Analysis, Report EPA-420-R10-006, Fevereiro 2010.

EREC - European Renewable Energy Council, Renewable Energy Technology Roadmap up to 2020, Janeiro 2007. 
EUROPA, European Biofuels Technology Platform, Biofuels Policy and Legislation, disponível em www.biofuelstp.eu/legislation.html acessado em 16/02/2013.

EUROPEAN COMMISSION, Energy Roadmap 2050, Luxemburgo, 2012.

EZEJI, T.C., QURESHI, N., BLASCHEK, P., Bioproduction of butanol from biomass: from genes to bioreactors, Current Opinion in Biotechnlogy, 18, 220-227, 2007.

FAPESP - Fundação de Amparo à Pesquisa do Estado de São Paulo, Programa BIOEN, disponivel em http://bioenfapesp.org, acessado em 15Jul2012.

FINEP, disponível em http://www.finep.gov.br/pagina.asp?pag=25.11, acessado em 16Out2012.

FOYLE, T.; JENINGS, L.; MULCAHY, P.: Compositional analysis of lignocellulosic materials: evaluation of methods used for sugar analysis of waste paper and straw Bioresource Technology, 98 (16), 3026-3036, 2007.

FROST \& SULLIVAN: Latin America Biofuels Markets, relatório NOD0-39, www.frost.com, 2006.

FROST \& SULLIVAN: Latin America Market for Second and Third Generation Biofuels, relatório N362-39, www.frost.com, 2008a.

FROST \& SULLIVAN: Latin America Biofuel Technology Trends, relatório N458-39, www.frost.com, 2008b.

GARCIA, M.L.; BRAY, O.H.; Fundamentals of Technology Roadmapping, SAND97-0665, Sandia National Laboratories, Abril 1997.

GARCÍA, V.a; PÄKKILÄ, J.; OJAMO, H.,; MUURINEN, E.; KEISKI, R. L.; Challenges in biobutanol production: How to improve the efficiency?, Renewable and Sustainable Energy Reviews 15 (2011) 964-980.

GERDSRI, N., VATANANAN, R.S., DANSAMASATID, S., Dealing with the dynamics of technology roadmapping implementation: a case study, Technological Forecasting and Social Change, 76, p. 50-60, 2009.

GEVO, Isobutanol - a renewable solution for the transportation fuel value chain Gevo White Paper, Maio 2011.

GEVO, Our Intellectual Property, disponível em http://www.gevo.com/ourbusiness/intellectual-property/, acessado em 16Out2012. 
GOLDENBERG, J. An historical account of bioenergy production in Brazil, $\mathbf{1}^{\text {st }}$ Brazilian BioEnergy Science and Technology Conference, Campos do Jordão, Agosto 2011.

GREEN, E.M., Fermentative production of butanol - the industrial perspective, Current Opinion in Biotechnology, Volume 22 (3) pp.337-343, 2011.

HARVEY, B.G., MEYLEMANS, H.A., The role of butanol in the development of sustainable fuel technologies, J Chem Technol Biotechnol, 86, 2-9, 2011.

IBARRA GONZÁLEZ, C.J., Sistematização do Processo de Mapeamento Tecnológico de Produtos, Dissertação (Mestrado), Universidade Federal de Santa Catarina, Engenharia Mecânica, 2007.

IEA - International Energy Agency, Bio-Based Chemicals: Value Added from Biorefineries, IEA Bioenergy, Task 42-Biorefinery, 2012.

IEA - International Energy Agency, Technology Roadmap Biofuels for Transport, 2010.

IEA - International Energy Agency, Technology Roadmap for Solar Photovoltaic Cell, 2010.

INDUSTRY CANADA, Technology Roadmapping: A Guide for Government Employees disponível em www.ic.gc.ca, acessado em 15Julho2012.

JANG, Y.S., LEE, J., MALAVIYA, A., SEUNG, D.Y., CHO, J.H., LEE, S.Y., Butanol production from renewable biomass: Rediscovery of metabolic pathways and metabolic engineering, Biotechnol. J., 7, 186-198, 2012.

JANG, Y.S., LEE, J., MALAVIYA, A., LEE, S.Y., Acetone-butanol-etanol production with high productivity using Clostridium acetobutylicum BKM 19, Biotechnol. Eng. , vol 110 (6) 1646-1653, 2013.

JANSSENS, R., Butanol scoping study: opportunities and threats for developing countries, disponível em www.fact-foundation.com, acessado em 180 ut2012.

JEFFREY, H., SEDGWICK, J., ROBINSON, C., Technology roadmaps: An evaluation of their success in the renewable energy sector Technological Forecasting and Social Change, in press, Nov 2012.

JIN, C; YAO, M.; LIU, H.; F.LEE, C; Progress in the production and application of $\mathrm{n}$-butanol as a biofuel, Renewable and Sustainable Energy Reviews, 15 (2011) 4080-4106.

KAMINSKI, W.; TOMCSAK, E.; GÓRAK, A.: Biobutanol: production and purification methods Ecological Chemistry and Engineering S., 18 (1): 31:37, 2011. 
KAPPEL, T.A.; Perspectives on roadmaps: how organizations talk about the future, Journal of Product Innovation Management., v18, n1, 39050, 2001.

KEAY-BRIGIT, S.; TAYLOR, G.; Developing a Bioenergy Roadmap for the UK, The UK Research Energy Centre, UKERC/MR/MP/2007/014, 2007.

KERR, C., PHAAL, R., PROBERT, D., Cogitate, articulate, communicate: the pysichosocial reality of technology roadmapping and roadmaps, $\boldsymbol{R} \& \boldsymbol{D}$ Management, 42 (1) p. 01-13, 2012.

KISTEP - Korea Institute of Science and Technology Evaluation and Planning, National Technology Roadmap (NTRM), Nov. 2002.

KUMAR, Manish; GOYAL, Yogesh; SARKAR, Abhiji; GAYEN, Kalyan; Comparative economic assessment of $A B E$ fermentation based on cellulosic and non-cellulosic feedstocks Applied Energy 93 (2012) 193-204.

KUMAR, Manish; GAYEN, Kalyan; Developments in biobutanol production: New insights Applied Energy 88 (2011) 1999-2012.

LEAL, R.L.V., Technology roadmapping: A fast track guide for the development of technology roadmaps for implementing a sustainable aviation biofuels industry in Brazil, NIPE - Núcleo Interdisciplinar de Planejamento Energético, 2012.

LEE, S., YOON, B., LEE, C., PARK, S., Business Planning based on technological capabilities: Patent analysis for technology-driven roadmapping Technological Forecasting and Social Change, 76 (6) p. 769-786, Jul 2009.

LEE, J.H., KIM, H., PHAAL, R, An analysis of factors improving technology roadmap credibility: A communications theory assessment of roadmapping process Technological Forecasting and Social Change, 79 (2) p. 263, Fev 2012.

LEE, J.H., PHAAL, R., LEE, C., An empirical analysis of the determinants of technology roadmap utilization, $\boldsymbol{R} \& \boldsymbol{D}$ Management, 41 (5) p. 485-508, 2011

LEE, S.; PARK, Y., Customization of technology roadmaps according to roadmapping purposes: Overall process and detailed modules, Technological Forecasting and Social Change, 72, p. 567-583, 2005.

LEE, S.; KANG, S.; PARK, E.; PARK, Y., Applying technology roadmaps in project selection and planning, International Journal of Quality and Reliability Management, 25 (1), p. 39-51, 2008.

LEONG, Y.C.; CHENG, T.G.; Technology Roadmapping for Top Management, the $11^{\text {th }}$ Asia Pacific Industrial Engineering and Management Systems Conference, Melaka, 7-10 Dezembro 2010. 
LOUREIRO, A.M.V.; BORSCHIVER, S.; COUTINHO, P. L. A.; The Technology roadmapping Method and its Usage in Chemistry J. Technol. Manag. Innov., Vol5, Issue3, 181-191.2010 (a).

LOUREIRO, A.M.V.; O emprego do método do technology roadmapping em adesivos e selantes aplicados à construção civil, Tese (Doutorado), Universidade Federal do Rio de Janeiro UFRJ, Escola de Química EQ, 2010 (b).

MANSUR, M., ABE fermentation of sugar cane in Brazil, Senior Design Reports, University of Pennsylvania (2010).

MARIANO, A.P., DIAS, M.O.S, JUNQUEIRA, T.L., CUNHA, M.P, BONOMI, A., MACIEL FILHO, R., Butanol production in a first-generation Brazilian sugarcane biorefinery: Technical aspects and economics of greenfield projects, Bioresource Technology, 135, pp. 316-323, Maio 2013.

MARIANO, A.P.; QURESCHI, N.; MACIEL FILHO, R.; EZEHI, T.C.; Assessment of in situ butanol recovery by vacuum during acetone butanol etanol (ABE) fermentation J. Chem. Technol. Biotechnol. 2012, 87: 334-340.

MARTINO, J.P.; Technological Forecasting for Decision Making; McGrawHill, 1993

MASCAL, M., Chemicals from biobutanol: technologies and markets, Biofuels, Bioprod. Bioref. 6:483-493 (2012).

MATTOS, P., LINCOLN, C.L., A entrevista não-estruturada como forma de conversação: razões e sugestões para sua análise, Rev. Adm. Pública FGV, 39 (4): 823-847, jul-ago 2005.

MELLO JUNIOR, D.C., Produção de Acetato de Etila em Biorrefinaria, Uma Análise de Viabilidade, Escola Superior de Agricultura Luis de Queiróz, ESALQ/USP, 2010.

MCTI, Estratégia Nacional de Ciência, Tecnologia e Inovação 2012-2015, Brasília, 2012

MELZOCH, K., PATAKOVA, P., LINHOVA, M., Experiences in the production and use of butanol as a biofuel, Department of Fermentation Chemistry and Bioengineering, Institute of Chemical Technology Prague, 2010.

MERQUIOR, D.M.; Gestão de Inovações e Tecnologia: Roadmap de Tecnologia, disponível em www.eceme.ensino.eb.br, acessado em 16/10/2009.

McDOWAL, W. Technology Roadmaps for transition management: The case of hydrogen energy, Technological Forecasting and Social Change, 79, 530542, 2012. 
MUNASCHINGHE, P.C., KHANAL, S.K., Biomass Derived Syngas Fermentation into Biofuels, Biofuels: Alternative Feedstocks and Conversion Processes, Elsevier, 2011.

NEJAME, S., Butanol as a Fuel - View from the field, Promotum, presentation to NREL, Março $11^{\text {th }}, 2010$.

NEXANT; Final Report: Liquid Biofuels: Substituting for Petroleum, Nexant Chem Systems, New York, Novembro 2006a

NEXANT, Biogasoline, Nexant Chem Systems, New York, Dezembro 2006b.

NEXANT, Oxo Alcohols 06/07-8, Process Evaluation Research Planning, Julho 2007.

NEXANT, Biobutanol: The Next Big Biofuel, topical report from Nexant Chem Systems, Fevereiro2008.

NI, Y., WANG, Y., SUN, Z., Butanol production from cane molasses by Clostridium saccharobutylicum DSM 13864: batch and semicontinuous fermentation, Appl. Biochem. Biotechnol. 166: 1896-1907, 2012.

NSF - National Science Foundation, Breaking the Chemical and Engineering Barriers to Lignocellulosic Biofuels: Next Generation Hydrocarbon Biorrefineries, University of Massachusetts, 2008.

OLIVEIRA, M.G; Integração do technology roadmapping (TRM) e da gestão do portfólio para apoiar a macro-fase de pré-desenvolvimento do PDP: estudo de caso em uma pequena empresa de base tecnologica, Dissertação (Mestrado), Universidade de São Paulo, Escola de Engenharia de São Carlos, 2009.

OLIVEIRA, M.G.; ROZENFELD, H.; "Alinhando o Technology roadmapping (TRM) e a Gestão de Portfólio" Seminário Technology roadmapping: Conceitos, Práticas e Perspectivas, Escola Politécnica da USP, 31 Agosto 2009.

OLIVEIRA, M. G., ROZENFELD, H.; Integrating technology roadmapping and portfolio management at the front-end of new product development, Technology Forecasting and Social Change, 77, 1339-1354, 2010.

OLIVEIRA, M.G., Roadmapping: Uma abordagem estratégica para o gerenciamento da Inovação em Produtos, Serviços e Tecnologias, Ed. Campus, São Paulo, 2012.

PEREIRA JR., N., COUTO, M.A.P.G., SANTA ANNA, L.M.M., Biomass of lignocellulosic composition for fuel ethanol production within the context of biorefinery., Series on Biotechnology, v.2, $1^{\text {a }}$ Edição, Escola de Química UFRJ, 2008. 
PHAAL, R., FARRUKH, CJ.P., and PROBERT, D.R.; Technology Roadmapping: linking technology resources to business objectives, UK, University of Cambridge, Department of Engineering, 2001 (a).

PHAAL, R., FARRUKH, CJ.P., and PROBERT, D.R.; Fast Start Technology Roadmapping, UK, University of Cambridge, Department of Engineering, 2001 (b) .

PHAAL, R., FARRUKH, C.J.P., PROBERT, D.R.; Technology roadmapping: A planning framework for evolution and revolution Technologcal Forecasting \& Social Change. 71, p. 5-26, 2004 (a).

PHAAL, R., FARRUKH, C.J.P., and PROBERT, D.R.; Customizing Roadmapping Research Technology, Vol 47, n. 2, p.26, 2004 (b).

PHAAL, R., MULLER, G.; An architectural framework for roadmapping: Towards visual strategy, Technological Forecasting and Social Change, 76, p. 39-49, 2009 (a).

PHAAL, R. Fast Start Technology Roadmapping, Seminário Technology roadmapping: Conceitos, Práticas e Perspectivas, Escola Politécnica da USP, 31 Agosto 2009 (b).

PHAAL, R. Roadmapping Bibliography, UK, University of Cambridge, Center for Technology Management, www.ifm.eng.cam.ac.uk/ctm/trm/resources, acessado em 160ut2009 (c ) .

PHAAL, R. , Public-Domain Roadmaps, UK, University of Cambridge, Center for Technology Management, www.ifm.eng.cam.ac.uk/ctm/trm/resources, acessado em 160 ut2009 (d) .

PHILLIPS, S., ADEN, A., JECHURA, J., DAYTON, D., EGGEMAN, T., Thermochemical Ethanol via Indirect Gasification and Mixed Alcohol Synthesis of Lignocellulosic Biomass, National Renewable Energy Laboratory - NREL, Technical Report NRL/TP-510-41168, Abril 2007.

PORTER, M., Clusters and the new economics of competition Harvard Business Review, Nov-Dez, 1998.

PORTER, M., The Five Competitive Forces That Shape Strategy Harvard Business Review, Jan, 1998.

PROBERT, D., Technology Research management at Cambridge, Seminário Technology roadmapping: Conceitos, Práticas e Perspectivas, Escola Politécnica da USP, 31 Agosto 2009 (a). 
PROBERT, D., Topics in Technology Management Research, Seminário Technology roadmapping: Conceitos, Práticas e Perspectivas, Escola Politécnica da USP, 31 Agosto 2009 (b).

PROCTOR, T., Marketing Research, Edinburgh Business School, Heriot-Watt University, Escócia, 2007.

RANJAN, A.; MOHOLKAR, V.S.; Biobutanol: science, engineering, and economics Int. J. Energy Res. 2012; 36: 277-323.

ROCHA, J.D., MESA PÉREZ, J.M., CORTEZ, L.A.B., Curso "Energia na Indústria de Açúcar e Álcool”, UNIFEI, Itajubá - Julho 2004.

RODRIGUES, J.A.R., Do Engenho à Biorrefinaria. A Usina de Açúcar como Empreendimento Industrial para a Geração de Produtos Bioquímicos e Biocombustíveis, Quim. Nova, Vol. 34, n. 7, 1245-1254, 2011.

SANTOS, M.F.R.F., Elaboração do technology roadmap para biorrefinaria de produtos de lignina no Brasil, Tese (Doutorado), Universidade Federal do Rio de Janeiro UFRJ, Escola de Química EQ, 2011.

SEABRA, J.E.A, Análise de opções tecnológicas para uso integral da biomassa no setor de cana-de-açúcar e suas implicações. Tese (Doutorado) Universidade Estadual de Campinas, Faculdade de Engenharia Mecânica, 2008

SMMT, Foresight Vehicle Technology Roadmap: Technology and Research Directions for Future Road Vehicles, V.2, 2004, disponivel em www.foresightvehicle.co.uk, acessado em 160ut2009.

SOUZA, A. M. G. F.. Efeito da adição de butanol na biodegradabilidade da gasolina e do diesel, Dissertação (Graduação), Universidade Estadual Paulista, Instituto de Geociências e Ciências Exatas, Rio Claro, 2009.

SOUZA, M.C.; Método de Mapeamento de Tecnologia Considerando a Estratégia de Technology Push e Adoção de Parcerias, Tese (Doutorado), Universidade de São Paulo, Escola de Engenharia de São Carlos, 2010.

SWANA, J.; YANG, Y.; BEHNAM, M.; THOMPSON, R.; An analysis of net energy production and feedstock availability for biobutanol and bioethanol, Bioresource Technology 102 (2011) 2112-2117.

SUCUMARAN, R.K., GOTTUMUKALLA, L.D., RAJASREE, K., ALEX, D., PANDEY, A., Butanol fuel from biomass: Revisiting ABE fermentation, Biofuels: Alternative Feedstocks and Conversion Processes, Elsevier, 2011. 
TAMMALA, S.B., JUNNE, S.G., PAPOUTSAKIS, E.T, Antisense RNA downregulation of coenzyme $A$ transferase combined with alcohol-aldehyde dehydrogenase overexpression leads to predominantly aldohologenic C.acetobutylicum fermentations, J. Bacteriol. 185, 3644-53, 2003.

THIOLLENT, M., Pesquisa-Ação nas Organizações, Ed. Atlas, São Paulo, 1997.

THORP, B.A., MURDOCK-THORP, L.D., Compeling Case for Integrated Biorefineries, Paper 360, Technical Association for Pulp and Paper Industry, Junho/Julho 2008.

VAN DER MERWE, A.B.; Evaluation of Different Process Designs for Biobutanol production from Sugarcane Molasses, Dissertação (Mestrado), University of Stellenbosch, South Africa, 2010.

VALENÇA, G.P., Hydrocarbons from Bioethanol, Purdue Workshop, Laboratório Nacional de Ciência e Tecnologia do Bioetanol - CTBE, Novembro 2012.

VAN BUEREN, M., VICENT, D., Eucalyptus biomass fuels: Price competitive or way off the money?, 47th Annual Conference of the Australian Agricultural and Resource Economics Society, Fevereiro 2003.

VILLELA FILHO, M.; ARAUJO, C.; BONFÁ, A.; PORTO, W., Chemistry Based on Renewable Raw Materials: Perspectives for a Sugar-Cane Based Biorefinery, Enzyme Research, Article ID 654596, 2011.

WANG, M., WU, M., HUO, H., LIU, J., Life-cycle energy use and greenhouse gas emission implications of Brazilian sugarcane and ethanol simulated with GREET model, International Sugar Journal, n. 1367, 2008..

WILLYARD, H.; McCLEES, W. Motorola's technology roadmap process, Research Management, 30 (5), 1987.

YASUNAGA, Y.; WATANABE, M.; KORENAGA, M.; Application of technology roadmaps to governmental innovation policy for promoting technology convergence, Technology Forecasting and Social Change, 76, n. 1, 61-79, 2009. 


\title{
APÊNDICE A - QUESTIONÁRIO DA PESQUISA
}

\section{Prospecção Tecnológica de Biobutanol no contexto brasileiro de biocombustíveis}

\author{
Mestrado
}

Orientadora: Profa. Dra. Désirée M. Zouain

agosto de 2012

Julio C. Natalense

++ 5511996421051

E-Mail: inatalense@usp.br 
O presente trabalho propõe o estudo de caso com uso da metodologia do technology roadmapping para identificação de necessidades e oportunidades no setor de biocombustíveis, destacando o biobutanol. É proposto aqui o mapeamento da cadeia de valor com prospecção de tecnologias existentes, entrevistas com fabricantes do setor, universidades, centros de pesquisa e formadores de opinião.

O objetivo geral da presente pesquisa consiste em: prospectar as necessidades tecnológicas e oportunidades para o biobutanol no cenário brasileiro de biocombustíveis, identificando diferenciais competitivos, econômicos e oportunidades para pesquisa e sustentabilidade do biocombustível brasileiro, em longo prazo.

São objetivos específicos:

- Estudar, diagnosticar e mapear as principais necessidades não atendidas da cadeia de valor do biobutanol no setor de biocombustíveis, identificando as vantagens competitivas em relação a outros tipos de produtos, em especial o bioetanol.

- Mapear as linhas tecnológicas de desenvolvimento, apontando direções para futuras inovações, utilizando as ferramentas da metodologia technology roadmapping (TRM), e adaptando este método ao presente estudo.

- Identificar oportunidades para recursos típicos do Brasil, como conversão de plantações de eucalipto ou cana-de-açúcar para produção de biobutanol.

Dados Iniciais: 


\begin{tabular}{|l|l|}
\hline Entrevistado & \\
\hline Cargo & \\
\hline Data & \\
\hline Empresa & \\
\hline Entrevistador & \\
\hline
\end{tabular}

As informações coletadas nesta entrevista, e os dados obtidos, serão tratados de maneira confidencial pelo pesquisador. As conclusões e observações serão relatadas de maneira genérica, sem referências diretas que identifiquem a sua fonte.

Assinale esta campo se você deseja receber um resumo contendo as principais conclusões da pesquisa

\begin{tabular}{|l|l|l|l|}
\hline SIM & & NÃO & \\
\end{tabular}

Parte A: Mercado

A1) Qual a oportunidade para BioButanol no mercado mundial?

Descreva, entre outros fatores, a substituição do butanol via petroquímica, o mercado potencial, o crescimento esperado para as rotas biológicas e seus prazos de implementação, o uso como combustível ou intermediário químico.

A2) Qual o potencial para o BioButanol no mercado brasileiro?

Considere, entre outros fatores, o potencial para consumo doméstico ou exportação.

A3) Qual o posicionamento de sua empresa no mercado mundial de butanol?

A4) Qual o posicionamento de sua empresa no mercado brasileiro de butanol?

Considere o posicionamento atual e a visão desejada.

A5) Quais países deverão liderar a produção de biobutanol ? 
Considere os predominantes que influenciam o diferencial competitivo de países (consumo interno de biocombustíveis, concorrência com outros combustíveis, cultura agrícola, incentivos à produção, pesquisa, base industrial instalada, marcos regulatórios e legais, etc).

A6) Considerando os 5 principais países listados na Questão A5, por favor classifique os prazos esperados para implementação da produção em escala comercial:

\begin{tabular}{|l|l|l|l|l|l|l|}
\hline & Existente & 1 ano & 5 anos & 10 anos & 20 anos & $\begin{array}{l}\text { Futuro } \\
+20 \\
\text { anos }\end{array}$ \\
\hline Pais (descreva) & & & & & & \\
\hline Pais (descreva) & & & & & & \\
\hline Pais (descreva) & & & & & & \\
\hline Pais (descreva) & & & & & & \\
\hline Pais (descreva) & & & & & & \\
\hline
\end{tabular}

A7) Qual será o posicionamento do biobutanol frente ao bioetanol no mercado?

A8) Quais as barreiras atuais à comercialização de biobutanol.

A9) Existem necessidades regulatórias a serem superadas? Quais são elas?

Considere as principais barreiras regulatórias e legais à implementação do biobutanol no mercado brasileiro. Qual a atuação de sua empresa? Qual a atividade do mercado / associações de classe ou órgãos governamentais?

A10) Qual o posicionamento do custo atual do biobutanol comparativo com seus principais produtos concorrentes / alvos?

Considere o custo de produção relativo entre butanol derivado de petróleo, e outros combustíveis (ex. Gasolina) ou biocombustíveis (ex. Biodiesel, bioetanol)

A11) Qual o patamar de custo é desejável para a ampla comercialização de biobutanol?

A12) Considerando os dados divulgados e públicos, quais os planos de comercialização de biobutanol por sua empresa? 
Considere quais as principais contribuições de sua empresa / instituição, quais as atividades recentes no mercado competitivo, quais as principais movimentações (novas empresas (Start ups), aquisições, fusões e parcerias de sua empresa).

A13) Considerando os aspectos abordados, por favor classifique os prazos para comercialização dos produtos no Brasil:

\begin{tabular}{|c|c|c|c|c|c|c|}
\hline & Existente & 1 ano & 5 anos & 10 anos & 20 anos & $\begin{array}{l}\text { Futuro } \\
+20 \text { anos }\end{array}$ \\
\hline $\begin{array}{l}\text { Butanol (derivado de } \\
\text { petróleo) }\end{array}$ & & & & & & \\
\hline $\begin{array}{l}\text { Bio (n-Butanol) } \\
\text { Intermediário quimico }\end{array}$ & & & & & & \\
\hline $\begin{array}{l}\text { Bio (iso-Butanol) } \\
\text { Intermediario quimico }\end{array}$ & & & & & & \\
\hline $\begin{array}{l}\text { Bio (n-Butanol) } \\
\text { combustivel }\end{array}$ & & & & & & \\
\hline $\begin{array}{l}\text { Bio (iso-Butanol) } \\
\text { combustivel }\end{array}$ & & & & & & \\
\hline
\end{tabular}

A14) Que outros aspectos ainda não abordados aqui são importantes ao mercado de biobutanol?

Parte B: Produto

B1) Que tipos de produto sua empresa desenvolve e comercializa?

\begin{tabular}{|l|l|l|}
\hline & Comercializa / produz & Desenvolve \\
\hline Bio (n-butanol) & & \\
\hline Bio (iso-butanol) & & \\
\hline Acetona & & \\
\hline Petro-butanol & & \\
\hline Outros (descreva) & & \\
\hline Outros (descreva) & & \\
\hline
\end{tabular}


B2) Quais os principais diferenciais do butanol como biocombustivel frente à gasolina?

B3) Quais os principais diferenciais do produto como biocombustivel frente ao bioetanol?

B4) Classifique em ordem de importância as principais características do biobutanol frente a outros combustiveis no Brasil:

1 = mais importante. $8=$ menos importante

\begin{tabular}{|c|c|c|c|}
\hline Fator & & Nota & Obs \\
\hline $\begin{array}{l}\text { Maior Poder Calorífico que } \\
\text { etanol }\end{array}$ & $\begin{array}{l}\text { Butanol tem maior poder } \\
\text { calorífico que etanol, o } \\
\text { que pode reduzir o } \\
\text { consumo de combustivel, } \\
\text { aumentando o rendimento } \\
\text { energético }\end{array}$ & & \\
\hline Baixa Volatilidade & $\begin{array}{l}\text { Menor perda de solvente } \\
\text { durante estocagem, } \\
\text { menor necessidade de } \\
\text { misturas em estações do } \\
\text { ano (verão/inverno) para } \\
\text { reduzir evaporação) }\end{array}$ & & \\
\hline Calor de vaporização & $\begin{array}{l}\text { Menos problemas com } \\
\text { ignição à frio. }\end{array}$ & & \\
\hline $\begin{array}{ll}\text { Solubilidade } & \text { com } \\
\text { combustiveis } & \end{array}$ & $\begin{array}{l}\text { Boa solubilidade do } n \text { - } \\
\text { butanol com diesel, e do } \\
\text { iso-butanol com gasolina }\end{array}$ & & \\
\hline Alta viscosidade & $\begin{array}{l}\text { Propicia lubricidade às } \\
\text { partes do motor }\end{array}$ & & \\
\hline Baixa higroscopicidade & $\begin{array}{l}\text { Compativel com atuais } \\
\text { linhas de distribuição / } \\
\text { bombas de combustivel }\end{array}$ & & \\
\hline Segurança no manuseio & $\begin{array}{l}\text { Baixa pressão de vapor e } \\
\text { ponto de fulgor elevado } \\
\text { tornam o produto seguro }\end{array}$ & & \\
\hline
\end{tabular}




\begin{tabular}{|l|l|l|l|}
\hline & $\begin{array}{l}\text { para uso a altas } \\
\text { temperaturas }\end{array}$ & & \\
\hline Fonte de hidrogênio & $\begin{array}{l}\text { Possibilidade de reforma } \\
\text { de butanol para uso em } \\
\text { células de combustível, ou } \\
\text { recuperação do } \\
\text { hidrogênio da } \\
\text { fermentação. }\end{array}$ & & \\
\hline
\end{tabular}

Referência: Jin, Chao "Progress in the production and application of n-butanol as a biofuel" Renewable and Sustainable Energy Reviews 15(2011) 4080-4106.

B5) Quais outros produtos / biocombustiveis oferecem concorrência / risco à ampla implementação do biobutanol no Brasil?

Considere, por exemplo, o bioetanol celulósico e o biodiesel.

B6) Que outros aspectos ainda não abordados aqui são importantes produto de biobutanol?

Parte C: Tecnologias

C1) Quais as linhas centrais de desenvolvimento de sua empresa?

C2) Quais as fontes de biomassa mais propícias à produção de biobutanol no Brasil?

\begin{tabular}{|c|c|c|c|c|c|c|}
\hline & Existente & 1 ano & 5 anos & 10 anos & 20 anos & $\begin{array}{l}\text { Futuro } \\
+\quad 20 \\
\text { anos }\end{array}$ \\
\hline Milho & & & & & & \\
\hline Cana-de-açúcar & & & & & & \\
\hline Florestal (eucalipto) & & & & & & \\
\hline Outros (descreva) & & & & & & \\
\hline
\end{tabular}




\begin{tabular}{|l|l|l|l|l|l|l|}
\hline Outros (descreva) & & & & & & \\
\hline Outros (descreva) & & & & & & \\
\hline
\end{tabular}

C3) Quais os microorganismos mais eficientes para conversão de biomassa

Quais as principais tecnologias em uso?

Quais os diferenciais / motivos? Quais as mais eficientes?

Em quais tecnologias sua empresa investe?

C4) Quais os prazos esperados para comercialização das seguintes tecnologias

\begin{tabular}{|l|l|l|l|l|l|l|}
\hline & Existente & 1 ano & 5 anos & 10 anos & 20 anos & $\begin{array}{l}\text { Futuro } \\
+20 \text { anos }\end{array}$ \\
\hline $\begin{array}{l}\text { ABE C. } \\
\text { Acetobulyticum }\end{array}$ & & & & & & \\
\hline ABE C.beijerinckii & & & & & & \\
\hline E.Coli & & & & & & \\
\hline S.Cerevisae & & & & & & \\
\hline Outros (descreva) & & & & & & \\
\hline Outros (descreva) & & & & & & \\
\hline
\end{tabular}

C5) Quais os principais desenvolvimentos no processo de fermentação?

Quais as principais tecnologias em uso?

Quais os diferenciais / motivos?

Quais as mais eficientes?

Em quais tecnologias sua empresa investe? 
C6) Quais os prazos esperados para comercialização das seguintes tecnologias

\begin{tabular}{|c|c|c|c|c|c|c|}
\hline & Existente & 1 ano & 5 anos & 10 anos & 20 anos & $\begin{array}{l}\text { Futuro } \\
+20 \text { anos }\end{array}$ \\
\hline $\begin{array}{l}\text { Fermentação em } \\
\text { batelada }\end{array}$ & & & & & & \\
\hline Fermentação contínua & & & & & & \\
\hline $\begin{array}{l}\text { Reator contínuo de } \\
\text { célula imobilizada }\end{array}$ & & & & & & \\
\hline $\begin{array}{l}\text { Reator com membrana } \\
\text { para reciclagem de } \\
\text { células }\end{array}$ & & & & & & \\
\hline $\begin{array}{l}\text { Gas stripping (contra } \\
\text { fluxo de gas) }\end{array}$ & & & & & & \\
\hline $\begin{array}{ll}\text { Extração } & \text { líquido- } \\
\text { líquido } & \end{array}$ & & & & & & \\
\hline Extração a vácuo & & & & & & \\
\hline Outros (descreva) & & & & & & \\
\hline
\end{tabular}

C7) Quais os principais desenvolvimentos no processo de destilação / recuperação de solvente?

Quais as principais tecnologias em uso?

Quais os diferenciais / motivos?

Quais as mais eficientes?

Em quais tecnologias sua empresa investe?

C8) Quais os prazos esperados para comercialização das seguintes tecnologias

\begin{tabular}{|l|l|l|l|l|l|l|}
\hline & Existente & 1 ano & 5 anos & 10 anos & 20 anos & $\begin{array}{l}\text { Futuro } \\
+20 \text { anos }\end{array}$ \\
\hline Destilação tradicional & & & & & & \\
\hline $\begin{array}{l}\text { Membrana } \\
\text { (pervaporação) }\end{array}$ & & & & & & \\
\hline Outros (descreva) & & & & & & \\
\hline
\end{tabular}


C9) Em geral, quais os principais gargalos no desenvolvimento de tecnologia?

C10) Quais os principais desenvolvimentos para superar os problemas descritos na seguinte tabela:

\begin{tabular}{|l|l|}
\hline & Comentários \\
\hline Esterelidade do substrato & \\
\hline $\begin{array}{l}\text { Baixo rendimento de butanol } \\
\text { em g/L }\end{array}$ & \\
\hline $\begin{array}{l}\text { Toxicidade do butanol aos } \\
\text { microorganismos do meio } \\
(20 \mathrm{~g} / \mathrm{L})\end{array}$ & \\
\hline
\end{tabular}

C11) Quais os prazos esperados para comercialização das seguintes tecnologias?

\begin{tabular}{|l|l|l|l|l|l|l|}
\hline & Existente & 1 ano & 5 anos & 10 anos & 20 anos & $\begin{array}{l}\text { Futuro } \\
+20 \text { anos }\end{array}$ \\
\hline $\begin{array}{l}\text { Rota Petroquímica } \\
\text { (Oxo-process) }\end{array}$ & & & & & & \\
\hline $\begin{array}{l}\text { Conversão de } \\
\text { etanol (Guerbet) }\end{array}$ & & & & & & \\
\hline $\begin{array}{l}\text { Hidrólise ácida de } \\
\text { biomassa } \\
\text { celulósica }\end{array}$ & & & & & & \\
\hline $\begin{array}{l}\text { Hidrólise } \\
\text { enzimática de } \\
\text { biomassa } \\
\text { celulósica }\end{array}$ & & & & & & \\
\hline $\begin{array}{l}\text { Gaseificação de } \\
\text { biomassa }\end{array}$ & & & & & & \\
\hline Algas & & & & & & \\
\hline Outro (descreva) & & & & & \\
\hline
\end{tabular}


C12) Quais os recursos técnicos de sua empresa?

Descreva os dados públicos de capacidade de laboratórios, plantas piloto e demonstração de processos, cooperação de sua empresa com outras companhias, universidades ou institutos de pesquisa no Brasil.

C13) Qual o cenário atual da propriedade intelectual em biobutanol?

Decreva empresas ou pesquisadores líderes, ou eventuais barreiras legais à comercialização

C14) Que outros aspectos ainda não abordados aqui são importantes à tecnologia de biobutanol? 